1. (2) $\ldots$  m.

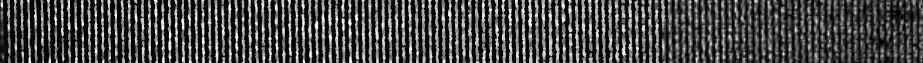
3. .

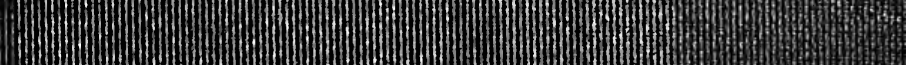
\begin{tabular}{|}
$\mid$ m \\
m
\end{tabular} W.

m m m m m m m



P. W. -2. 1 m m. 
BR 115 .P7 C86 1915 Cunningham, William, 18491919.

Christianity and politics 


CHRISTIANITY AND POLITICS 



\title{
CHRISTIANITY AND POLITICS
}

\author{
BY \\ WILLIAM CUNNINGHAM, D.D., F.B.A.
} ARCHDEACON OF ELY

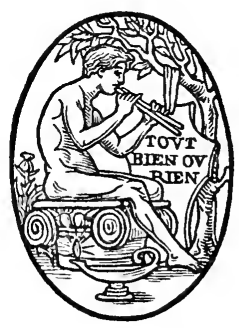

BOSTON AND NEW YORK HOUGHTON MIFFLIN COMPANY

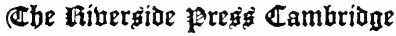


COPYRIGHT, 1915, BY WILLIAM CUNNINGHAM

ALL RIGHTS RESERVED

Published November 1915 


\section{PREFACE}

THe bearing of Christian teaching on the life of the community is a matter of great interest from many points of view. In lectures at the London School of Economics in 1913 I endeavoured to deal with the relations of Christianity and Economic Science, reserving for the time the practical questions as to political duty: this was the subject of the course of Lowell Lectures which I had the honour of delivering in the autumn of 1914. There has been the greatest difference of opinion between different bodies of Christians as to the mode of bringing Christianity to bear on political life, and the differences are so fundamental that it is worth while to examine them in turn, and see how far each opinion has justified itself as a matter of practical experience. The more we are aware of the danger of giving exaggerated importance to any half truth, the better prospect there will be of finding common ground, on which all can work together without any sacrifice of principle. The Lowell Lectures, as originally written, were chiefly concerned with the internal government of a community; but the war has given importance to all questions of international 


\section{PREFACE}

relations; and in revising the lectures for publication I have endeavoured to take account of national life in all its aspects. The appendix, on the Attitude of the Church towards War, is part of a memorandum written at the request of a Committee of the Lower House of Convocation of the Province of Canterbury, which had been appointed to consider the subject of the Church and War.

Trinity College, Cambridge, W. C.

so July, 1915. 


\section{CONTENTS}

\section{INTRODUCTION}

War as an Anachronism.

Appeal to Christianity.

Disappointed Expectations.

Maxims for Society.

Personal Sense of Duty.

I. Christendom and the Reforma
I. The Papacy.
Spiritual and Civil Authority.
The Secularising of Papal Power.

The Counter-Reformation.

II. External Siritual Authority.

Bishop Ketteler and Social Questions.

Papal Claims.

Diminishing Influence.

Failure to give Definite Guidance.

III. The Aloofness of Anglo-Saxon PeoPLES.

Papal Enunciation of Truisms.

Suspicion of Clerical Interference.

Loss to Christian Studies.

II. Church and State in England • • 30

I. National Life.

The Church as National.

The Appeal to the Bible.

Loyalty to the Crown.

Sense of Mission.

The Gentry and the Council. 


\section{CONTENTS}

\section{The Administration of a Christian}

Realu.

Ecclesiastical and Civil Authorities.

The Relief of the Poor.

The Enforcement of Fish Diet.

Objection to Usury.

Attacks on the Stuart Administration.

III. The Right to Coerce.

Coercing People for the Common Good.

A Common Order in Worship.

Economic Progress.

The Art of Leadership.

III. Presbeterianism and the Supremacy of SCRIPTURE • • • • • • • .

I. The Scriptural Model for a Polity.

Reaction from the Synagogue of Satan.

A Godly Nation.

The Magistrates and Force.

Freedom for Capital.

The Spiritual Independence of Ministers.

II. Presbyterian Theocracy.

A Christian Community.

Education and Poor-Relief.

Industrial Requirements and Prudential Virtues.

Capital and the New Slavery.

III. The Danger of Misusing Scripture.

The Bible and Principles for a Polity.

Economic Laws.

Society and Individuals.

IV. Independents and the SUPRemacy of Conscience • • • • • • • • . 92

I. Personal Conviction and Gathered

Churches.

Gathered Churches.

The Duties of the Community.

Attack upon the Parochial System. 


\section{CONTENTS}

II. Administrative Duties and the Society of Friends.

Official Duty.

Civil Rights.

Public Responsibilities.

III. Christian Assoclations.

Withdrawal to the New World.

External Relations and Internal Regulation.

The Two Spheres.

IV. Unassimilated Elements in English SoCIETY.

The Clarendon Code.

The Assertion of Personal Rights.

The Elimination of Religion from Politics.

V. The Grounds of Civil Obedience.

The Duty of Civil Obedience.

Refraining from Active Obedience.

The Appeal to Force.

Duty to the Community and to God.

V. Religion and Public Spirit .

I. Self-Discipline and Growth.

Personal Religious Life.

Services and Societies.

John Wesley and Methodism.

II. The Duties of the Community.

Pulpit Exhortations.

National Mission and National Duty.

Self-Interest and Public Spirit.

Trading Companies, and Planters.

Duty to the Poor and to Dependents.

Hospitals and the Humane Society.

The Anti-Slavery Movement.

III. The Prosperity of the Community.

Improving Landlords and Enterprising Capitalists.

Individual Loss and the Progress of the Community 


\section{CONTENTS}

\section{Humanitarianism and Coercion . .167}

I. The Abandonment of Laissez-faire.

Adam Smith.

State Support of Philanthropic Efforts.

Public Health.

The Corn Laws.

II. Coercion and Duties of Other People.

Public Opinion.

Public Benefits and Ideal Justice.

III. Reliance on State Interference.

Desire for Political Power.

Decline of Personal Responsibility.

Coercion of Other Nations.

Humanitarianism and War.

IV. Political Christianity.

The Church as the Handmaid of Politicians.

Fanaticism.

The Special Work of Christianity.

VII. Class Interests and National InterESTS . . . . . . . . .

I. Substitutes for the Sense of Duty.

Co-operative Societies, and Copartnership.

Friendly Societies and Trade Unions.

II. Inadequacy of Clanss Interests.

Beneficial Effects.

Possibilities of Conflict.

III. National Interests.

The Evils of War.

The Insecurity of Peace.

Sordid Polities.

VIII. Christian Duty in a Democracy . 219

I. Modern Perplexities.

Indifference to Religion.

Social Unrest.

Spiritual Influence.

Personal Responsibility to God. 


\section{CONTENTS}

II. Duties as a Citizen.

Party Government.

Disparaging Politics.

Motive Force for doing Duties to the Community.

Duty as to Investments.

III. Duties of Private Life.

The Employer of Labour.

Public Companies.

IV. Christian Organisation.

Personal Sense of Duty.

Intellectual Error.

Inspiring Examples.

Local Organisation.

APPENDIX •

The Attitude of the Church towards War.

I. The Acceptance of War as Inevitable IN AN EVIL WorLd.

The Sub-Apostolic Age.

Christians and Military Discipline.

St. Augustine and Just Wars.

II. The Christian Polity and the ConseCRation OF War.

The Extension of Christendom by Force.

The Military Orders.

Private War and the Peace of God.

Wars of Religion.

The Protest of Anabaptists and Friends.

Sanctified Common Sense.

INDEX • • • • • • • • • • 265 



\section{CHRISTIANITY AND POLITICS}

\section{INTRODUCTION}

The European War has caused an extraordinary strain on the resources of the nations engaged in it. Each combatant is trying to put out its full strength and to organise the energies of labour and the wealth of capitalists with a view to military operations; each is striving to the utmost to obtain success. Such a trial of strength must have far-reaching results; war is an ordeal which not only strains material resources, but tests the habits of thought and accepted axioms of political life. Till July of last year there was a general belief in England and America that war had become an anachronism; that, though it might survive among half-civilised and decadent peoples, it could no longer occur amongst the most highly developed nations. It seemed impossible that there should be such an outrage on civilisation. On the one side, humanitarian sentiment was likely to prevent an outbreak of war, with all the misery it entails; on the other, the interests of the nations of the world were so interdependent that it seemed unlikely that any could gain by means of war. But events have proved that the hopes 


\section{CHRISTIANITY AND POLITICS}

which were so generally entertained were baseless; a nation, distinguished for scientific culture and for effective organisation, has forced on a war, and horrors which were looked upon as a thing of the past have been let loose on a larger scale than ever before. Pacificism, which professed to be the last result of scientific sociology, has been discredited as impracticable in Europe, since events have proved the ineffectiveness of humanitarian sentiment and prudential calculation, to prevent an appeal to arms.

During the last year there has also been fresh recognition of religion as a force in political life; for a century and more there had been a tendency to wave it aside and discard it as no longer a matter of public concern. The persistence of the philanthropists was not indeed wholly forgotten, and Christianity was expected to interfere with the internal affairs of the nation, and to rouse the national conscience on such questions as the sweating of labour and the improvement of housing. Apart, however, from social reform, religion seemed to many men to be a matter of private concern, and no one regarded it as entering directly into the field of international politics. With the stress and anxiety of war all this is changed, and Christianity has taken its rightful 


\section{INTRODUCTION}

place. The depth and fervour of religion in Russia has been a revelation to the Western world. The Kaiser has appealed to the faith of his people that God will give victory to the Germans, and render Teutonic ideas triumphant throughout the world; while English statesmen call on the Church to use her influence and support them in a sacred cause. The present war has forced men to realise, as they were ceasing to do, that Christianity has an important part to play in shaping the destinies and maintaining the influence of a nation.

Christianity, when thus appealed to, speaks with an uncertain sound; different ideals are cherished and different opinions are put forth as to the attitude which is right for the Christian man in regard to war. Religion may be the strongest incentive to courage in battle, as it was in Old Testament times, and in the tide of conquest by which Mohammedanism was spread in the East and West. Their religion was the inspiration for the struggle of the Huguenots in France, and the Ironsides in England; but it seems to have increased the bitterness of parties and to have added fuel to the flames of political passion. Their common Christianity did not prevent the outbreak of war between European nations; yet this is inconsistent with the conception of Christianity as first preached and as now accepted. 


\section{CHRISTIANITY AND POLITICS}

Many who feel little need of a religion in their own lives approve of the ideal of society which Christianity sets forth. It promises the advent of a Prince of Peace, and holds out the hope of a time when war shall be no more. Those who are enamoured of this prospect for the world at large are disappointed that the expectations which Christianity has raised have not been fulfilled. Its failure to maintain peace at the present time seems to them to discredit religion as unpractical, and its teaching as unfitted for the present world. But this raises the question whether the failure is due to Christianity itself, or to mistaken methods of pursuing the Christian aim. An inquiry as to the method by which Christianity is likely to work most effectively, as a power for regenerating human society, is not only interesting but fruitful. Forgotten controversies come to have a new meaning, when it is remembered that the men who took part in them were making different experiments as to the method of realising the Christian aim in this world. In the seventeenth century and subsequently one experiment was tried after another; and various bodies attempted to found a Christian polity that should be in complete accordance with the will of God. We can examine these polities in turn, and see how far the basis on which each rested was really sound. Some relied 


\section{INTRODUCTION}

on the positive guidance of a living authority; ${ }^{1}$ some treated the Scriptures of the Old and New Testament as an ultimate standard ${ }^{2}$ while others insisted that the individual conscience must be supreme. $^{3}$ We can note how the structures, which were built on one or other of these foundations, have been arraigned at the bar of history, and how defects or exaggerations have been exposed. This enquiry is not idle, if we are prepared to learn by the experience of the past. Beacons, which warn us what to avoid, may give us important guidance as to the course we ought to pursue.

Christianity still maintains a claim to mould personal life and national life; but religion would do well to abandon the pretension to lay down principles in a form in which they are directly applicable to the circumstances of any community, at the precise stage of development which it has reached. In the modern world there is progress and growth; and no maxims can be formulated which apply to every age alike. The laws of Political Economy are ultimately based on experience, and hold good for long periods; there is need to take them into full account, but none of them is to be treated as valid for all time. One system of Political Economy after another has been superseded, and none has attained finality. Our
${ }^{1}$ Chapter I.
${ }^{2}$ Chapter III.
${ }^{3}$ Chapter IV. 


\section{CHRISTIANITY AND POLITICS}

religion fails to live up to its true character if it attempts to enunciate maxims which give direct guidance to political communities. For "Chris"tianity is the Eternal Religion which can never "become obsolete. If it sets itself to determine "the temporary and the local, the justice of this "tax, or the exact wrongs of that conventional "maxim it would soon become obsolete, - it "would be the religion of one century, not of all."1 It is to the personal heart and conscience that the teaching of Christ makes its primary appeal; the Christian man is taught to aim at so passing through things temporal that he shall not lose the things eternal.

The problems of modern life are complex, and the misery of human beings in the most advanced communities is appalling. It is therefore right that we should try to learn from past experience. Christian effort is wasted when it is frittered away in every direction, instead of being concentrated on the field in which it can work most effectively. Christianity has a unique power for dealing with the heart and conscience of the individual man, and it will do well to exercise this power to the full, as the best means of bringing its influence to bear, indirectly but not the less really,

1 F. W. Robertson, Sermons (2d Series), II, 7. 


\section{INTRODUCTION}

on Society as a whole. There is hope that the part which religion has to play in political life may be more effective than ever, if Christian men can learn from their own past failures, and not only awaken to a keener sense of personal duty, but also keep an open mind to the actual conditions in which they live. Humanitarian sentiment is a power for good, though it cannot create a new earth. ${ }^{1}$ Class Interest and National Interest are notable forces, though they are mischievous if they are allowed to operate blindly. ${ }^{2}$ No exclusive Christian principle of action in social affairs is to be advocated as a substitute for the play of human activities. Divine power can so master them as to give each its place, and bring them all to cooperate for the common weal. If the good and the evil elements in the social forces of the day are recognised, Christians need no longer treat them as antagonists, but welcome them as possible allies. "He that is not against us is on our part."

${ }^{1}$ Chapter VI.

${ }^{2}$ Chapter VII. 


\section{I \\ CHRISTENDOM AND THE REFORMATION}

\section{THE PAPACY}

Throughour the whole of Western Christendom there had been a general agreement, during the Middle Ages, that the Papacy was the channel by which the Divine Will for all conditions of human life was authoritatively made known; and also that it was the organ by which Christian duty could be enforced, either by the spiritual censures or through the co-operation of Christian princes. Generations of men grew up in a society which was permeated by these views and accepted them without serious question. Hildebrand succeeded in maintaining the supremacy of the spiritual power, while its independence of secular authorities appears to be guaranteed by the possession of the States of the Church; and this view has never been abandoned. It is still claimed that the temporal power "was conferred many centuries ago "by Divine Providence on the Bishop of Rome "that he might without let or hindrance use the "authority conferred by Christ for the eternal 


\section{CHRISTENDOM AND THE REFORMATION}

"welfare of the Nations." 1 However imperfectly this might be realised in actual life, there was at least a general recognition of one harmonious system throughout Christendom so long as one common authority on moral and social duty was generally accepted. "This Apostolic Chair it "was that gathered and held together the crum"bling remains of the old order of things; this was "the kindly light by whose help the culture of "Christian times shone far and wide; this was an "anchor of safety in the fierce storms by which "the human race has been convulsed; this was "the sacred bond of union that linked together "nations distant in region and differing in char"acter; in short, this was a common centre from "which was sought instruction in faith and re"ligion, no less than guidance and advice for the "maintenance of peace and the functions of "practical life." 2

Hence it is maintained that the improvements in social life, during the Middle Ages, were accomplished by the influence exercised on secular authority by the central spiritual power. "The "Almighty therefore has appointed the charge of "the human race between two powers, the Ecclesi-

1 Pope Leo XIII, The Pope and the People. Select Letters and Addresses on Social Questions, 17.

2 Ibid., 19. 


\section{CHRISTIANITY AND POLITICS}

"astical and the Civil; the one being set over Di"vine, and the other over human things. Each in "its kind is supreme, each has fixed limits within " which it is contained, limits which are defined by "the nature and special object of the province of "each; ${ }^{1}$. . . one of the two has for its proximate "and chief object the well being of this mortal life; "the other the everlasting joys of heaven. What"ever, therefore, in things human is of a sacred "character, whatever belongs either of its own na"ture or by reason of the end to which it is re"ferred, to the salvation of souls, or to the worship " of God, is subject to the power of the judgment " of the Church. Whatever is to be ranged under "the civil and political order is rightly subject to "the Civil authority." "2 But as there is no equivalence between these two aspects of human life, there can be no hard and fast line drawn between the two powers. "Just as the end at which the "Church aims is by far the noblest of ends, so is its "authority the most exalted of all authority, nor "can it be looked upon as inferior to the Civil "power, or in any manner dependent upon it." 3 "God has willed that one should be the head of "all, and the chief and unerring teacher of truth." 4

1 Pope Leo XIII, The Pope and the People, 79.

2 Ibid., 80.

3 Ibid., 77.

4 Ibid., 77. 


\section{CHRISTENDOM AND THE REFORMATION}

This was the conviction which governed society during the Middle Ages; and it is easy to show that, so long as it held sway, the national jealousies and the social difficulties, which have arisen in the modern era, were less chaotic, since there was a spiritual authority, to which appeal might be made, and which had a recognised position for dealing with them.

During the later Middle Ages there had been a widespread complaint that the Church was becoming secularised. The temporal power was not merely a guarantee for spiritual independence but a basis for frequent interference in European politics and for rivalry in magnificence with other courts.

The life of St. Francis and the foundation of his Order is a monument of disapproval of the secular elements in ecclesiastical institutions, even among those who fully acknowledged the authority of the Pope; and this alienation was strengthened in many quarters by the Renaissance and the progress of humanism. The secular aspect of the Papacy became more pronounced than before, and the critics were furnished with new weapons to attack the old order.

All this paved the way for the rejection of the claims of the Papacy to exercise authority 


\section{CHRISTIANITY AND POLITICS}

over civil powers. The severance of Christendom, and the revolt of the Lutherans and the English from Rome, were far less due to the theological questions about the Sacraments, which came into the forefront in the controversies of the day, than to the fact that the claim of a secularised Church to exercise spiritual authority over the civil power no longer found the acceptance which had been generally accorded to it for centuries. It is clear that in various parts of England, at all events, strong antagonism was felt to the disuse of the old ritual and to the changes introduced by Henry VIII. Indeed it is commonly admitted that the English Reformation was political, rather than religious, but it is a mistake to ascribe it to a personal whim which was carried through in a high-handed fashion by Henry VIII. The King was only able to give effect to his views, because the traditional respect for the spiritual authority of a secularised Papacy had been already undermined.

There was one particular exercise of the Papal authority, as an international arbiter, which gave rise to widespread resentment among people in England, especially English mariners; they had been keenly interested in the voyages which led to the discovery of the New World; and they bitterly resented the decision of the Papacy, which 


\section{CHRISTENDOM AND THE REFORMATION}

handed over these new lands either to Spain or to Portugal, and left no scope for the northern peoples to have a share in this great development.

The English pioneers in trade and colonization were not to be held back by a decision of this sort. They refused to admit the authority of the Potentate who had pronounced it; and, as time went on, popular feeling became more and more bitter; not only were the English prohibited from direct access to the new lands, but trade with Spanish and Portuguese dominions was hampered by increasing difficulties. The Inquisition looked askance at English merchants who temporarily settled in Spanish ports or at the Canaries. ${ }^{1}$ The story of cruelties which were undertaken in the name of religion, and which were exemplified in England during the reign of Queen Mary, had a great effect in awakening a widespread repugnance. A wave of horror spread over England at the massacre on St. Bartholomew's Day. Many men who did not aspire to form their own opinions on theological questions had difficulty in believing that an authority which could only be maintained by such measures was really and truly Christian, and the respect for the Papacy as a spiritual authority was dissipated.

1 Royal Hist. Soc., Trans. III, (Series III,), 257. 


\section{CHRISTIANITY AND POLITICS}

The disorders which arose in connection with the Reformation movement were so various and so embittered that there seemed to be good ground for believing that the restoration of the authority of the Pope was a necessary preliminary to any reconstruction of social and political life. This view was enthusiastically maintained by Ignatius Loyola and the Jesuits, who became the devout adherents of the Papal See: under their leadership the Counter-Reformation had no little success in the sixteenth and early seventeenth centuries. It seemed for a time that if the Traditional Ecclesiastical authority were exercised on modern lines it might be completely reinstated in Western Christendom. The Jesuits have been the object of frequent suspicion as a political danger, but they have kept their ground and continue to be the backbone of Ultramontanism; and the principles they promulgated in regard to political and social life have greatly influenced the position which is taken by Roman Catholics in the present day. Devout Roman Catholics appear to hold that Christianity can only be brought to bear on social and political life through the agency of a Divinely appointed spiritual authority, and that the recognition of this authority is a necessary preliminary to any efforts for the amelioration of society which can hope to be fruitful and lasting. In democratic 


\section{CHRISTENDOM AND THE REFORMATION}

countries Roman Catholics are reactionary politically, even when they have been specially active in advocating particular social reforms.

\section{EXTERNAL SPIRITUAL AUTHORITY}

A very remarkable work for dealing from a Christian standpoint with all the acknowledged social evils of the day - the miseries of the poor, the responsibilities of the rich, the greed and ruthlessness of capital, and the disintegration of society - was initiated by Bishop Ketteler of Mainz. He made a striking pronouncement at a Catholic Congress, in 1848, as to the importance of the task of bringing religion to bear upon social conditions, ${ }^{1}$ and eventually he had an extraordinary success in organising a body of earnest Christians who devoted themselves to social reform. The history of the German Catholic Congress shows how rapidly this work has developed. It has brought devout Christians into close contact with the aspirations and efforts of the democracy for material improvement. ${ }^{2}$ It has done much to smooth away the influence of class prejudices, and it has brought various societies for the promotion of human welfare into closer and conscious cooperation. ${ }^{3}$ It has also exercised a considerable

1 Plater, Catholic Social Work in Germany, 8.

2 Dawson, Evolution of Modern Germany, 112.

3 Plater, op. cit., 99. 


\section{CHRISTIANITY AND POLITICS}

political influence through the Centre Party in Parliament, and the activity of its newspaper press. The principles and the methods on which Ketteler acted have received the sanction of Papal authority, and have inspired in no small degree the remarkable series of Encyclicals which Pope Leo XIII gave to the world. But the effort to undertake and carry on this social work of reorganisation was intimately connected, in Ketteler's own mind, with the recognition and maintenance of Papal authority. His own determination to throw his personal activities into the cause of the Church seems to have been due to his intense feeling at the indignities put on the Archbishop of Cologne, when he was imprisoned at Minden in 1837. ${ }^{1}$ Towards the close of his life, when, in May, 1873, the laws which interfered with the liberties of the Church, in teaching and preaching, were passed, Ketteler took a leading part in the fight for spiritual independence which was known as the Kultur Kampf; it was only when the State had withdrawn from a position that was proving untenable that the Christian social activities which he had initiated could be effectively resumed. His attitude on this matter has also been endorsed by the Pope, who writes, "Seeing, "therefore, that all the hopes of Italy and of the

1 Plater, Catholic Social Work in Germany, 5. 


\section{CHRISTENDOM AND THE REFORMATION}

"whole world lie in the power so beneficent to the "common good and profit, wherewith the author"ity of the Apostolic See is endowed, and in the "close union which binds all the faithful of Christ "to the Roman Pontiff, We recognise that nothing "should be nearer Our heart than how to preserve "safe and sound the dignity of the Roman See, "and to strengthen ever more and more the union " of members with the Head, of the children with "their Father." 1

The claim, which was put forward by Leo XIII in regard to Christian action in the time of peace, is renewed by Benedict $\mathrm{XV}$ as essential for the effective action of the Church in the present war: "For a long time past the Church has not enjoyed "that full freedom which it needs, never since the "Sovereign Pontiff, its Head, was deprived of " that protection which by Divine Providence had "in the course of ages been set up to defend that "freedom. . . . All from far and near who profess "themselves sons of the Roman Pontiff, rightly "demand a guarantee that the common Father of "all should be, and should be seen to be, perfectly "free from all human power in the administration "of his apostolic office. And so while earnestly "desiring that peace should soon be concluded

1 The Pope and the People, 21. 


\section{CHRISTIANITY AND POLITICS}

"amongst the nations, it is also Our desire that "there should be an end to the abnormal position "of the Head of the Church, a position in many "ways very harmful to the very peace of nations. "We hereby renew, and for the same reasons, the "many protests Our Predecessors have made "against such a state of things, moved thereto not "by human interest, but by the sacredness of our "office, in order to defend the rights and dignity "of the Apostolic See." 1

The assertion of this claim, to maintain or reintroduce the recognition of an external spiritual authority, has been the cause of political difficulties and divisions in not a few countries; and this may be noted, not with the view of coming to any decision as to the right or wrong of the claim, but simply in order to gauge whether there is any immediate prospect that it will become effective. If Christian Social Reform is dependent on the recognition of an outside spiritual authority, it is to be feared that this reform will be indefinitely delayed. The controversy in regard to the Kultur Kampf arose out of the desire of Prussia to assimilate the population of recently acquired provinces on the Rhine and in Poland, so that the whole realm might become more homogeneous. The result of the struggle has been to accentuate these

1 Encyclical, 1 November, 1914. Tablet, 12 December, 1914, p. 170. 


\section{CHRISTENDOM AND THE REFORMATION}

differences, to lower the respect for civil authority, and to diminish the sentiment of loyalty. ${ }^{1}$ At the same time, it may be doubted whether the Christian influence, as thus organised, in regard to social matters is really increasing. There is at least some reason to believe that the Roman Catholic element in the north of Germany is becoming of less importance relatively in the life of the State, and is not growing so as to hold its own in existing circumstances. ${ }^{2}$

In Belgium the Catholic Social Movement had been wonderfully successful in exercising a very real political influence by securing a majority in the Belgian Chambers; since 1883 a large number of valuable measures for the limiting of the hours of labour and the improvement of the conditions of work ${ }^{3}$ have been passed. With these the clerical party are in fullest sympathy, and may fairly claim credit for them, though it is not clear that they have initiated them or could have carried them through unaided. There was also much uncertainty as to the power of the clerical party to retain their position and to continue to exercise a dominating influence.

Further, while this movement does not appear

${ }^{1}$ G. Bazin, Windhorst, 250. A. L. Lowell, Governments and Parties, II, 12.

2 Rost, Die wirth. und kult. Lage der deutschen Katholiker, 184.

8 Max Turmann, Le développement du Catholicisme social, 96, 272. 


\section{CHRISTIANITY AND POLITICS}

to be growing in the country in which the first impulse was felt, it shows few signs of spreading; it has not been successfully initiated either in Italy or France. In France there is indeed such a division of opinion, between those who are in sympathy with socialism and those who are in sympathy with individualism, that there is little hope of such effective organisation for social purposes as has been created in Germany. ${ }^{1}$ During the last generation, an immense amount of labour legislation, in regard to Workmen's Compensation and Insurance, and the regulation of factories, has been passed in France, but the Roman Catholic influence in support of it has been so slight as to be almost negligible.

The Encyclicals of Leo XIII are exceedingly interesting as showing the sympathetic attitude which had been adopted by the Pope and very many clergy of the Roman Church towards the aims of the democracy. But they are not after all very successful in giving us authoritative guidance in regard to the social difficulties of the day. They are indeed valuable as a statement of a carefully formed opinion; but the very form, which they necessarily take, prevents them from meeting the actual requirements of the day. The dicta

1 Day, Catholic Democracy, 282. 


\section{CHRISTENDOM AND THE REFORMATION}

of an external authority must necessarily be stated in general terms, and by the laying down of broad principles. In international disputes the Papal pronouncements have been ineffective because they are merely the announcement of humanitarian sentiments ${ }^{1}$ or the statements of truisms about natural justice; they show no signs of insight and power of discrimination. There never has been a war when it was impossible to put forward some grievance as a pretext for appealing to arms or to maintain that justice required that a wrong should be avenged. For the Sovereign Pontiff, " as supreme interpreter of the " eternal law," to " proclaim that for no reason is it "allowable to injure justice," is a waste of words, so long as he thinks it improper to "entangle the "pontifical authority in the disputes between "belligerents." 2 Similarly, the difficulties of life 1 Benedict XV, "Letter to the Catholic World," The Tablet, September 26, 1914, p. 436. "Those who rule the affairs of peoples "We urgently implore and conjure that they now turn their minds "to forget all their own discords for the sake of the salvation of "human society; that they consider that already there is enough "misery and trouble in the life of men that it should not be rendered " "for a long time more miserable and troubled; that they be satisfied "with the ruin wrought, the human blood already shed; that they "initiate councils of peace and reconcile themselves; for thus will "they truly deserve well of God and of their own peoples, and will be "benefactors of the civil society of the nations. And for Us, who at "this, the very beginning of Our Apostolic Office, see grave troubles "in the terrible disorganization of all things - let them know that "they will be doing a thing most pleasing to Us and one which from "all Our heart We desire."

${ }^{2}$ The Tablet, January 30, 1915, p. 156. 


\section{CHRISTIANITY AND POLITICS}

in a progressive state of society are primarily those of applying the principles. The conditions of life, and the possibilities of individual improvement and of collective production, are changing from day to day and hour to hour. New forms of social organisation are being evolved; traditional principles seem to be mere statements of truisms or of pious aspirations, and an external spiritual authority can do little in bringing these principles into effect. The Roman Church is compelled to abstain from direct political action; she cannot identify herself with any political party in the State nor with Socialism in so far as it asserts the predominant importance of materialistic aims; and as she cannot coalesce with the extreme Collectivism of the Socialist school, she is also debarred from allying herself with the extreme Individualism of the opposite Liberal school. ${ }^{1}$ But party government is the most effective agent for political action in democratic communities, and of this weapon the Church, through its acceptance of an external spiritual authority, cannot make use.

Even in giving advice to private individuals the scope of the action of the Roman Church is limited. There are many particular questions of right and justice on which her members are divided, and from which the Church holds aloof.

1 Day, Catholic Democracy, 233. 


\section{CHRISTENDOM AND THE REFORMATION}

Types of these questions are - the exact fixing of the limits of State intervention, the arrangements of just wages as between masters and servants, the determination of the relative value of different kinds of labour, and the precise apportioning of the rewards of industry to the various agents who conjointly produce it. In regard to such questions the Church has no immediate message, and she refuses to arbitrate. ${ }^{1}$ Nor has the Pope ever succeeded in reconciling the conflicting claims of different principles which are urged by various parties in the present day. Much is said of the principle of justice, but it is not always easy to see in what way this principle is interpreted. In the early Middle Ages the principle of justice as an economic guide was chiefly concerned with the consumption of goods, and was interpreted as meaning that every member of a community should share according to his needs. In modern times it had been more generally interpreted with reference to production, and as implying that each member of a community should share according to his contribution to the resources of the community. ${ }^{2}$ But neither of these interpretations will serve in great modern democracies by itself and alone; from the principle that each should share

1 Day, Catholic Democracy, 234.

${ }^{2}$ Cunningham, Christianity and Economic Science, 29. 


\section{CHRISTIANITY AND POLITICS}

according to need the conclusion may be deduced that any or all have a right to live in idleness. On the other hand the principle, that each should receive in strict accordance to the contribution he makes to the resources of society, is very hard upon the helpless and inefficient. Neither statement can be applied generally to society, without serious mischief; while it seems impossible to reconcile these formulæ when stated in general terms.

The problems presented to the Christian man by life in modern society solvuntur ambulando. The difficulty about Christian principles vanishes if they are regarded not as principles for the organisation of society, but as the basis of personal duty in society; they may furnish us, each and all, with conceptions of what our personal conduct ought to be. The principle of distribution according to need is the basis of the personal Christian duty of alms-giving, and it is for each one of us to interpret his ability conscientiously for himself. The principle of remuneration according to contribution is the basis of the social duty of work. It is incumbent upon each man to see that his work is so diligent and thorough that he is making an adequate contribution for the share he receives from society, and this applies as much to those who are engaged in 


\section{CHRISTENDOM AND THE REFORMATION}

organising business or in the pursuit of knowledge as it does to manual labourers. In actual life and personal conduct, there is little difficulty in reconciling the two principles, and it is possible to be strenuous in giving effect to both. What is chiefly needed from the Christian point of view in the present day is the exercise of a spiritual power to awaken individuals to a sense of duty and to inspire them to do it. The Salvation Army has had an extraordinary influence in convincing men of the reality of the spiritual as a factor in human life, because it has dealt with individuals personally; while the laying down of external principles in general terms would be of comparatively little help in the special circumstances of the present day. From the religious point of view the social doctrine of the Encyclicals is excellent ethically, but it is unconvincing and uninspiring; it has not the marks of spiritual authority to which the individual conscience is drawn to respond.

\section{THE ALOOFNESS OF ANGLO-SAXON PEOPLES}

While the Roman Church as an effective guide in the solution of political and social difficulties seems to have made little progress during the last decade on the Continent, there is no indication 


\section{CHRISTIANITY AND POLITICS}

that the Anglo-Saxon peoples are prepared to reverse the decision which was taken at the Reformation and to accept guidance from Papal authority. ${ }^{1}$ There are no signs in the political world of a readiness to submit to an external spiritual authority; but this does not mean that these peoples are altogether indifferent about bringing a religious influence to bear on political life; it means that they hold that spiritual influence may be most effectively exercised on the individual personally, - that the appeal to the individual conscience is the most direct which can be made, that it is least encumbered by secular forms, and that it bears fruit immediately in action on a larger or smaller scale. Hence it appears probable that whatever progress the Roman Church may make in recovering lost ground, as regards the spread of theological doctrine and habits of worship, there is no weakening in the opposition to accepting the guidance of an external authority in political and social life. The English Reformation was based on this principle, and the deep-seated repugnance to national submission to Rome still rests on the same foundation.

There is a very general tendency to regard the Roman Catholic community with suspicion, and

1 There is a widespread feeling, put by M. Latapie in definite form, that the Papal See may be so far concerned in protecting its own interests as to fail to be an impartial arbiter. Times, 23 June, 1915. 


\section{CHRISTENDOM AND THE REFORMATION}

to believe that they have a sense of duty to look primarily at the possibility of fostering the Roman Church, and only secondarily at the good of the community as a whole, whether it is a city or a nation. From the point of view of the Romanist, who believes that the good of the community as a whole can only be attained through submission to the Roman Church, this distinction does not exist; but it is strongly present in the minds of many members of the community, and the conflict is always apt to arise over questions in regard to marriage and to facilities for the religious education of children. Owing to these points of cleavage it becomes difficult to treat society as a homogeneous whole, and the effectiveness of national organisation is endangered. But further than this, these points of difference may be the occasion of deep-seated cleavage. In the Prussian Kingdom the influence of the Papacy was strongly felt among the Poles and the people of the Rhine Provinces, and the Kultur Kampf proved a hindrance to the growth of a national life. In a similar fashion the Papal influence is strong among the Celtic population of Ireland, ${ }^{1}$ and the fear of the measures which might be adopted in a Dublin Parliament and of partiality in the administration of the laws through clerical intrigue, has

1 Plunkett, Ireland in the New Century, 99. 


\section{CHRISTIANITY AND POLITICS}

haunted the people of Ulster in their opposition to Home Rule. It is even possible that a similar cleavage will show itself in some of the United States; and that in these areas, where the French Canadians or the Irish are a dominating majority, alarm may be raised as to the possibility of a complete departure from the American tradition in regard to political and social life. How far these fears and suspicions may be justified is not a point on which it is worth while to express an opinion, but the fact remains that the Roman Church has had, and is likely to continue to have, comparatively little opportunity of bringing religious influence to bear on the political and social life of the Anglo-Saxon peoples.

From many points of view this severance is a matter of great regret, especially as it has prevented Christian opinion in England and America from taking such full account, as it deserves, of the work of Roman Catholic writers. Amid the chaos of opinions which are expressed by different authors in the name of Christianity, or as deducible from Christianity, Roman writers have preserved a remarkably sane and judicial tone; even those readers who do not find them convincing can hardly fail to regard them as impressive; they never allow themselves to forget that the work 


\section{CHRISTENDOM AND THE REFORMATION}

of the Church is essentially spiritual, and that the importance of material conditions is only incidental and not the main work for which the Church exists. They do not allow themselves to fall into false abstractions, and to look on society as merely mechanical, but give its full importance to human personality. They are not carried away by the feeling that we have entered on a new era, to which the experience of past ages is altogether irrelevant, so that it may be ignored. The fact that the various writers look at these problems from a common standpoint and have adopted the same principles, gives a certain unity to their treatment of the questions that come under review. They put forward not merely the expression of personal opinion, affected by personal temperament and individual experience, but the teaching of a school. The broad lines which are laid down in the Encyclicals are worked out in fuller detail by Turmann in a book which is especially interesting in the discussion of usury and capital; ${ }^{1}$ and the writings of Father Day on Democracy, of Cardinal Vaughan and of the late C. S. Devas on Economics, if they do not give definite guidance to the community as to practical conduct, are at least a very great help to clear and consistent thinking.

1 Max Turmann, Le développement du Catholicisme social, 152. 


\section{II \\ CHURCH AND STATE IN ENGLAND}

\section{NATIONAL LIFE}

There were many personal elements which entered into the English Reformation and tended to obscure the main issue, but a fundamental principle was involved in the breach with Rome. King Henry VIII claimed that the Crown was supreme over all causes in England and he refused to allow appeals in ecclesiastical matters to Rome. He was followed in his repudiation of the spiritual authority of the Roman See by Edward VI, Elizabeth, James I, and Charles I. This protest against Roman encroachment on the English realm, as they had come to regard it, was not merely negative; it implied that England was a self-sufficing Empire which could rule its own affairs of every kind. Church and State were two aspects of the same community; and, during the sixteenth and early seventeenth centuries, this double character of national life was consciously borne in mind in all administrative details. During the Middle Ages it had been recognised that there were two aspects of Christendom, a spiritual side controlled by the 


\section{CHURCH AND STATE IN ENGLAND}

Pope, while the Emperor was supreme over civil affairs; but the area where the Imperial authority extended was not coterminous with that of the ecclesiastical rule of the Papacy, and the frequent antagonism of the two heads of Christendom prevented the ecclesiastical and civil authorities from conscious co-operation. In England the area of royal authority both in Church and State was clearly defined, and there was a fusion, or at all events close co-operation, between the two bodies of administrators such as had never existed before. Henry VIII and his son, Elizabeth and her two immediate successors all endeavoured to order the national life as a Christian polity, - to exercise administrative authority in regard to things spiritual, as well as civil authority in secular affairs. The title page of Cranmer's Bible, which represents King Henry VIII as distributing the Bible to be a guide for national life, depicts the Bishops and ecclesiastics on the one side and the civil authorities on the other, and represents both as the media by which right feeling and good government might be diffused among the people.

The claim to exercise an administrative authority in spiritual affairs was not by any means new; it had been universally held that the civil power in the person of the Christian Prince was called upon to foster religion, and this duty might obvi- 


\section{CHRISTIANITY AND POLITICS}

ously involve attempts to improve ecclesiastical efficiency. Much had been done in Spain to remove abuses in the Church, and the establishment of the Inquisition in 1497 was an earnest attempt, on the part of the Crown, to maintain at once purity of religion and purity of race. Papal authority over ecclesiastical affairs in Spain was reduced to a minimum. Again, the Emperor Charles V had endeavoured to mediate between the various religious parties in Germany and to establish an Interim over ecclesiastical arrangements by secular power. The claim of Gallican liberties in France was another step in the same direction, and Henry VIII was probably hardly conscious that he was going beyond existing precedents; both he and Elizabeth carefully guarded themselves against any claim to personal authority in things spiritual, but relied on the Spirituality of the Realm for guidance instead of on an external spiritual authority. But this distinction could only be drawn because King Henry was able in the Reformation era to put forward a new spiritual authority to which he might appeal. With the written guidance of the Bible on the one hand to give evidence in regard to the essentials of Christianity for all time, and the living tradition and institutions of the English Church on the other, he maintained that the religious 


\section{CHURCH AND STATE IN ENGLAND}

aspect of national life could be rightly ordered without habitual reliance on an outside authority.

The English Church was thus truly national, but it also maintained its character as spiritual, since it did not recognize any earthly power or written law as in itself supreme but looked to a living God above all earthly things. In the Prayer Book the blessing of God is asked for the King and Parliament and other Civil Authorities, who are directly responsible to God for the management of public affairs. The Lutherans had maintained the strong confidence which Luther placed in the Princes, through whose exercise of their powers the cause of the Reformation was preserved and law and order maintained; the Kaiser continues this tradition, and is ready to identify the particular polity over which he rules with the Kingdom of God. In the seventeenth century this was commonly done by professing Christians, but, in the present day, it seems to be fanatical; even in Tudor and Caroline times, however, the English Prayer Book and Homilies gave no countenance to this error. The existence of bad princes who bring punishment and defeat on their people was not forgotten: ${ }^{1}$ the truth that God is the supreme arbiter and that we should approach Him, not with a consciousness of right, but confessing our

1 Homily 21. 


\section{CHRISTIANITY AND POLITICS}

sins and humbly imploring His blessing, so that our efforts may bring about the triumph of good and promote His glory, is the dominant note in the prayers for time of war and for sailors before a battle; there is no hint of exclusive claims to Divine favour and the tone throughout is spiritual, as the prayers are concerned with actual conflicts, not merely with the results that may be secured. The language of the English Prayer Book is wonderfully free from the assumption which runs through the Old Testament, and which was inherited from the Middle Ages, of identifying an earthly polity with the cause of God.

The English Church, in repudiating the authority of the Pope, did not accept an absolute monarchy, and did not treat the Bible as the last word in all matters of secular government. The appeal to the Bible was a fundamental factor in the Reformation both in Germany, Scotland and England; but in England it was different in character from that of the thorough-going Protestant. The Calvinists turned to the Bible as a supreme rule of life; while the English Reformers regarded it as a test by which to judge of the cumbersome and unnecessary in ecclesiastical institutions and religious worship. They recognised that there were corruptions in the Mediæval Church and that many observances were superstitious; 


\section{CHURCH AND STATE IN ENGLAND}

they needed a test by which to discriminate as to the things which might be sacrificed without loss. The New Testament was evidence as to primitive simplicity, it therefore showed what was essential for all time; and they treated usages and doctrines, which could not claim scriptural authority, as excrescences which need no longer be preserved in the religious life of the realm. Monasticism had been developed in the West in the fourth century and there was no scriptural authority for the existence of monastic institutions; it was generally admitted that there was need for reform, and the silence of Scripture was an excuse for a sweeping dissolution. The changes which were made by Cranmer in doctrine and ritual were put forward as applications of this principle; and on the other hand, the English Reformers retained everything that appeared to be consonant with Scripture, when allowance was made for the inevitable differences between the conditions of a missionary church in a heathen empire and the institutions which were appropriate to a Christian polity. They found ample evidence of ecclesiastical organisation in Apostolic times, and of the enforcement of ecclesiastical discipline. It did not appear that there was any necessity to alter the form of government which had come down continuously from a distant past, or to do away with 


\section{CHRISTIANITY AND POLITICS}

the episcopate and the enforcement of ecclesiastical discipline in ecclesiastical courts. The direct appeal to the Bible severed the English nation in its ecclesiastical aspect from Latin Christendom, while the limited nature of that appeal as a negative test and the preservation of the traditional ecclesiastical institutions separated it from the Protestant communities, whether Lutheran or Calvinistic.

There were circumstances which had tended to bring the Central Government and the people into closer touch during the sixteenth century, and helped to strengthen the sense of national solidarity. The centralising policy of the Tudors had broken down much of the feudal independence of the great families, and rendered the royal will more effective in all parts of the realm, than it had been before the Wars of the Roses; but while the royal power was unrivalled, the Crown was yet becoming more directly and more frequently dependent on taxation for the means of the government of the country. The King could no longer live of his own; he was forced to rely on the contributions of the people and the general resources of the realm. Hence the community of interest between the King and his subjects came more clearly into consciousness, and Hales explained 


\section{CHURCH AND STATE IN ENGLAND}

that the King cannot have treasure when his subjects have none. ${ }^{1}$ Royal interest was combined with royal duty in efforts to see that the people prospered. The people looked consciously to the Crown as the power which would save them from absorption in one or other of the great Latin monarchies, and the Crown looked to the general prosperity and loyalty of the realm as the main support on which reliance could be placed.

The central government had also taken over a large number of administrative duties which had hitherto been administered locally by civic authorities or manorial lords. This local administration had apparently fallen into hopeless decay during the fifteenth century, and the attempts to galvanise it into life were by no means successful. Under Elizabeth the gigantic task was undertaken of putting all local administration under the direct supervision of the Crown. Parliament legislated on such subjects as the conditions of work, and the terms of employment, the rates of payment, and the provision for the poor, the quality of goods, and the conditions of sale, and especially as regards the food of the people. In regulating the details of economic life, the towns of the Middle Ages had attained their greatness by conscious efforts to promote the good of the civic community

1 Hales, Discourse of the Commonweal, 35. 


\section{CHRISTIANITY AND POLITICS}

in the long run, and to put down all that savoured of mere private interest and was inconsistent with the good of the town as they conceived it, especially with its ability to discharge the burden of royal taxation. In the Elizabethan period this civic sentiment was superseded by a wider and national enthusiasm. There was a conscious desire to bring the various economic forces in all parts of the realm into co-operation so that they might promote the prosperity, and especially the political power of the community, - not merely of a town, but of the realm as a whole. The Crown could be regarded as detached from local and private interests, and as concerned with the prosperity of the whole realm. It was occupied with larger interests than those of particular localities and particular trades, though it was concerned to see that each locality and trade was contributing to the common good. Hence there was the emergence of a new public spirit; the Crown and Lords and Commons as legislators, and the King and his Council as administrators and supervisors, were making themselves responsible for national prosperity in all its forms. The more enterprising section of the community was especially dependent on the good offices of the Crown. The opening of new markets and the obtaining of trade concessions could only be secured by political negotia- 


\section{CHURCH AND STATE IN ENGLAND}

tions with foreign powers; while good order within the realm, and the provision of an adequate food supply in many towns and districts, were secured by effective administration. Industrial and commercial interests were consciously dependent on the Crown, while the Crown was directly interested in their prosperity.

It is also true to say that the organisation of the Church was rendered more national than it had ever been before. The separate uses of different dioceses were swept away; and the two provinces of Canterbury and York were brought into closer contact when the same regulations were enforced upon both, and a common order, embodied in the Book of Common Prayer, was adopted throughout the realm. The clergy, who had accepted the Reformation movement, were keenly alive to the dangers of the situation, and relied upon the Crown as the bulwark against the CounterReformation on the one hand, and the revolutionary changes of the Calvinists on the other. Their sense of dependence on the Crown, as the administrative head of the Church, called forth expressions of loyalty which seem in the twentieth century to be exaggerated. The homilists lay a somewhat disproportionate stress on the duty of civil obedience, and Elizabeth took it for granted that one of the main duties of the clergy as 


\section{CHRISTIANITY AND POLITICS}

preachers was to inculcate the duty of loyalty to the Crown, so that the administration of public affairs might be conducted smoothly and without friction. From the circumstances of the time the Crown was the representative of the community as a whole, both as regards the religious side of national life and well-ordered economic progress. The Crown was a source of honour or advancement, the power and honour of the Crown was inextricably connected with the welfare, not of one section of the community only, but of the whole; and hence loyalty to the Crown was the most obvious of social duties.

Just as attachment to the Reformed religion and loyalty to the Crown were curiously blended in the patriotism of Elizabethan times, so religious and secular aims were combined in the attempts which were made for the expansion of England. The sense of religious mission, which had pervaded Christendom at the time of the Crusades, was not wholly dead; it was revived in a more definite form as a sense of national mission to the tribes of the New World. So long as England stood upon the defensive there was little scope for this feeling to assert itself, but the discomfiture of the Spanish Armada opened up new possibilities to the English. Hitherto they had 


\section{CHURCH AND STATE IN ENGLAND}

been on the defensive, seeking to maintain national existence; but in 1588 they had proved their right to take a part in the struggle for world power. The rival which had hitherto threatened their existence now barred their progress. Spain had absorbed Portugal, and the English resentment was concentrated on the institutions, commercial, political and religious, of the Spanish Monarchy. Englishmen had a conscious pride in their own country which comes out in Harrison and Holinshed and the Debate of the Heralds; they felt it a duty to prevent the Spaniards from dominating the American continent, and to bring English influence to bear on the development of these vast territories. The Journal of Drake and the accounts of the first colonists in Virginia ${ }^{1}$ are sufficient to show how closely the sense of a national mission to benefit the world, by diffusing English influence, was combined with the practical objects which the pioneers of the English Empire had in view.

In the sixteenth century and for long afterwards the landed gentry were politically the most important element in the population. Under the old fiscal system they contributed very largely to public resources, and they were also, as magis-

${ }^{1}$ Cunningham, Growth of English Industry, Ir, 336. 


\section{CHRISTIANITY AND POLITICS}

trates, responsible for local government and for carrying out administrative regulation. There always had been land owners; but the landed gentry of the Elizabethan period had a somewhat different character from their predecessors. The great families with their household of retainers, who had fought in the Wars of the Roses, were extinct as a class; and many of the new gentry were inclined to devote themselves to the improvement of their estates and to the duties of civil life.

In some cases it appeared that agricultural improvement was pushed on ruthlessly, in disregard of long standing customary rights; ${ }^{1}$ where these changes brought about a definite increase in the resources of the realm, it was plausible to plead that a public benefit was attained in spite of the incidental grievance created; and the Crown recognised that the influence of the resident gentry was essential to the good government of the counties and placed on the justices an ever-increasing burden of responsibility. ${ }^{2}$ The obligation to perform unpaid service for the community had been recognised from time immemorial in regard to such parochial offices as those of the church warden and the constable, ${ }^{3}$ but under the Tudors

1 Tawney, Agrarian Problem, 373.

2 Webb, Parish and County, $294 . \quad{ }^{3}$ Webb, op. cit., 15, 40. 


\section{CHURCH AND STATE IN ENGLAND}

this principle received an extended application in connection with county government. There are numbers of proclamations which show how earnestly the Government desired that the gentry should reside on their estates. ${ }^{1}$ The number of manor houses, which had no military character, though they were often protected by a moat, are monuments which show that a large measure of success was attained. There were undoubtedly wastrels among these landed men who were of little good either to themselves or to their neighbours; but an extraordinarily high sense of duty, both to their posterity and to the public, became traditional among them as a class. It was their ambition to hand on their estate improved to a son; and the desire to found a family and to provide for its prosperity in the future, was the motive which led to the introduction of new methods of land management, and to agricultural progress.

On the other hand, the desire to attain to status in the management of county affairs, was an ambition that was widely cherished through the class, and made men eager to give their leisure to public duties. The Lords Lieutenant and County Magistrates were men who were entrusted by the Crown to organise the county for military

1 Cunningham, op. cit., II, 105. 


\section{CHRISTIANITY AND POLITICS}

purposes and for the punishment of crime. The Council exercised an effective supervision, and were prompt to deal severely with neglects; and this impressed on the country gentry, as a class, a strong sense of duty to maintain good order.

As owners of property they were conscious of responsibility, and their status among their neighbours really depended on their readiness to undertake public duties, and the skill with which they discharged them: they were the chief agents on which the Crown could rely for securing good government within the realm; and they also took an active part in the enterprises which led to the expansion of England. Younger sons, who had little prospect of securing a maintenance for themselves at home, had enterprise enough to attempt, with some of the family dependents, to carve out estates in lands across the seas and thus to establish plantations. There has often been occasion to dwell on the defects of the English country gentleman, but it may be doubted whether there has ever been a body of wealthy men with such a deep sense of the responsibility of property, and of the duty of managing it well. Certainly a strong tradition has been established among them as to the obligation of a leisured class to expend time and trouble voluntarily over public service. 


\section{CHURCH AND STATE IN ENGLAND}

II. THE ADMINISTRATION OF A CHRISTIAN REALM

Since there was so little attempt to separate the religious from the secular aspects of national life, it was natural that no hard-and-fast line should be drawn between the organs which were primarily concerned with the one and those which were primarily concerned with the other. In the Middle Ages a great deal of the work of civil administration had been put in the hands of ecclesiastics, partly because they were more competent than other men to discharge the delicate duties of diplomacy and to be entrusted with great responsibilities; and the old tradition was maintained to a certain extent after the Reformation, especially in the time of Charles I. General dissatisfaction was expressed at the way in which the King placed ecclesiastics, like Laud and Williams, in civil offices; but these were only a striking example of a common characteristic. In the Elizabethan period and under the Personal Monarchy, the elements which are now habitually distinguished were confused in the Christian realm, as then conceived; the religious and the secular were blended, and the whole realm was organised with the view of promoting the good, religious, political and economic, of the community. Since Church and 


\section{CHRISTIANITY AND POLITICS}

State were not thought of as distinct, but as one community in two aspects, it was natural that the authorities in Church and State should cooperate for the common weal, and should try to promote it by any means that lay to hand. At the centre of government, where supervision was exercised over the whole realm, clergy and laity might be called upon to work together in the King's Council: in larger areas, such as the county, the civil magistrate was the effective authority, though bishops and archdeacons had an important part to play; while in smaller areas, such as the parish, the responsibility rested with the constable as well as with the parish priest; and the churchwardens were concerned in seeing that the national life, both in its civil and in its religious aspect, was well ordered.

The chief administrative difference lay in the manner in which the different authorities could enforce their decisions; the civil authorities could of course fall back on fine and imprisonment and other serious punishments, while the ecclesiastical courts were for the most part only able to impose spiritual censures on the laity, though heavy money charges might occasionally arise in connection with their proceedings, and they could deprive the clergy of their livings; in fact the difference between the two sets of authorities might be 


\section{CHURCH AND STATE IN ENGLAND}

indicated by saying that whereas the civil power could exercise coercive jurisdiction, ecclesiastical authority was on the whole restricted to moral suasion.

One of the most noticeable changes of the Elizabethan period was that which was carried out in regard to the relief of the poor. The great social upheaval which accompanied the Reformation, and the stimulus to industrial and agricultural improvement which was given by commercial expansion, resulted in a dislocation of the old social order, and a great increase of pauperism. The old facilities for the distribution of charity no longer existed, and the alms which were given in the parish churches were not adequate to meet the case. Drastic Poor Laws were passed, and a new system of administering poor relief was brought into operation, and entrusted to civil authorities who had the power of distraining for the quota at which the well-to-do owners and occupiers in a parish were assessed. The administrative change in creating civil parishes, for the administration of funds collected under compulsion, had very important after results, as it gave the right to certain persons to claim relief as due to them under the law of the land. Had the administration continued under the ecclesiastical authorities with a 


\section{CHRISTIANITY AND POLITICS}

moral and not a legal character, this claim would not have been set up. For generations it gave rise to much litigation, in attempts to establish in different cases the precise locality which was responsible for the maintenance of some particular persons; and in the period of distress, which arose in connection with the Industrial Revolution, this system had a very demoralising effect on large sections of the community who had become dependent on State aid. These ulterior consequences could not of course be foreseen; and when the main responsibility was transferred to civil authority, scope was left for the exercise of Christian charity as a personal thing through the old ecclesiastical channels. The alms at the Communion continued to be distributed to the poor and were often employed to give additional help to those who were not wholly dependent on relief. There was also, in the later sixteenth and seventeenth century, a widely diffused readiness to make lasting provision for certain classes of the poor; in almost every parish in England, charities were founded for such objects as providing the necessitous with fuel and cloaks in winter, for the distributing of doles of bread, for erecting almshouses for those who were past work, or for providing schools. The spirit of neighbourliness and of Christian beneficence as a personal duty con- 


\section{CHURCH AND STATE IN ENGLAND}

tinued to flourish, even after the parochial duty to maintain the poor had been transferred to civil authority.

It was thought convenient to enforce other duties, which were mainly political, through the ecclesiastical administration. The institution of Lent was one that had given rise to a considerable demand for fish, and there was some fear at the time of the Reformation that the fishing trade would suffer through the disuse of the practice of keeping fish days; accordingly statutes were passed in Parliament to keep up the traditional habit on political grounds; the fishing industry was a great school of seamanship and supplied mariners to be employed in the defence of the realm and in commerce; the decay of seamanship would be a disaster to an island realm. Since, however, the practice had had an ecclesiastical character it was convenient that it should be maintained by ecclesiastical authority. ${ }^{1}$ Laud's correspondence shows that he was at pains to enforce it strictly, and did not readily give licenses to those who desired to evade the restrictions on their diet. Parliament insisted that the compliance with this order had no religious character, but found it convenient to exercise moral pressure

1 Cunningham, op. cit., II, 72. 


\section{CHRISTIANITY AND POLITICS}

on the public through ecclesiastical administration.

Ecclesiastics were also concerned in maintaining the traditional standard of duty in regard to the employment of money and the getting of gain. Public opinion, at the close of the sixteenth century, had become very lax; and under the changed circumstances which accrued from the large importation of precious metals from the New World, the hardships which might easily arise in old days in connection with certain forms of bargains, were likely to be rare. The old distinctions as to what was right and wrong appeared to be untenable or idle, but Bishop Andrews ${ }^{1}$ and others of the leading clergy adhered to them. How far there were systematic attempts to enforce the traditional morality in the ecclesiastical courts $^{2}$ it is impossible to say; but the duty of presenting those who made an extortionate use of their capital is laid down in the 109th Canon of 1604; and the Statute of 1624, which permitted the taking of moderate interest, so far as civil authorities were concerned, carefully disclaimed giving any decision in regard to cases of conscience. The sense of personal duty, in regard to the manner in

1 Cunningham, op. cit., II, 153.

2 One case is recorded at Pickering in 1600. Yorkshire Archœological Journal, xvinI, 331. 


\section{CHURCH AND STATE IN ENGLAND}

\section{which money was employed, was not allowed to}

fall out of sight in the Stuart times. The Council in $1622^{1}$ took a very decided view as to the duty

1 E. M. Leonard, Early History of English Poor Relief, 147. The Council writes " to call before you ${ }^{\mathrm{u}}$ such clothiers as you shall thinke fitting and to deale effectually $w^{\text {th }}$ them for the imployment of such weavers, spinners and other persons as are now out of worke. Where wee maye not omitt to let yo ${ }^{u}$ know that as wee have imployed or best endeavors in favo $^{r}$ of the clothiers both for the vent of their cloth and for moderation in the price of wooll (of $\mathrm{w}^{\mathrm{ch}}$ wee hope they shall speedily find the effects). Soe maye wee not indure that the cloathiers in that or any other countie should att their pleasure and $w^{\text {th }}$ out giving knowledge hereof unto this Board, dismisse their worke-foelkes, who being many in nomber and most of them of the poorer sort are in such cases likely by their clamo ${ }^{\text {rs }}$ to disturbe the quiet and governmente of those parts wherein they live. And if there shalbe found greater numbers of poore people then the clothiers can reviue and imploy, Wee thinke it fitt and accordingly require $\mathrm{yo}^{\mathrm{u}}$ to take order for putting the statute in execution, whereby there is provisione made in that behalfe by raising of publicke stockes for the imployment of such in that trade as want worke. Wherein if any clothier shall after sufficient warning refuse or neglect to appeare before yo ${ }^{u}$ or otherwise shall obstinately denie to yeeld to such overtures in this case as shalbe reasonable and iust; you shall take good bonds of them for refusing to appeare before us and immediately certifie their names unto this board."

The Council also say the woolgrowers must sell their wool at a moderate price, and finish up with the statement of the general principle on which they act. "This being the rule," they say, "by w $^{\text {ch }}$ both the woolgrower, the cloathier and merchant must be governed. That whosoever had a part of the gaine in profitable times since his $\mathrm{Ma}^{\text {ty }}$ happie raigne must now in the decay of Trade ... beare a part of the publicke losses as may best conduce to the good of the publicke and the maintenance of the generall trade."

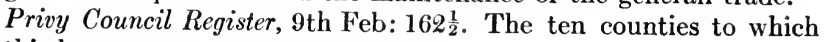
this letter was sent are as follows: -

$\begin{array}{ll}\text { Wilts. } & \text { Gloucester. } \\ \text { Somerset. } & \text { Worcester. } \\ \text { Dorset. } & \text { Oxford. } \\ \text { Devon. } & \text { Kent. } \\ \text { York. } & \text { Suffolk. }\end{array}$

Compare also Butler, Victoria County History, Gloucestershire, II, 159. 


\section{CHRISTIANITY AND POLITICS}

of capitalist employers in times of bad trade towards those whom they employed.

It has been the fashion to treat the break-down of the Personal Monarchy under the Stuarts as a matter of temperament, and to contrast the loyalty which was evoked by Queen Elizabeth with the unpopularity of James and the suspicions aroused by Charles I. It is doubtless true that the traits of personal character had somewhat incidentally contributed to the downfall of the system. But these trivialities were by no means the sole cause of the collapse of the Personal Monarchy. The system of rule in Church and State was anomalous, and it would hardly have been possible for the most ingenious statesmen to continue to steer the ship through these troubled waters with success; indeed it may be urged that there were some aspects of national life in which the prosperity, which had begun under Elizabeth, continued to make further progress under the Stuarts. There was a great increase of national resources of every kind; commerce was expanding, new industries were being developed, and pains were being taken to reclaim large areas for cultivation and to improve production from the soil. The problem of absorbing the poor in the economic life of the country seems to have been prac- 


\section{CHURCH AND STATE IN ENGLAND}

tically solved for the time. The plantation of Ireland had gone on apace, and the colonisation of the New World had begun. The Personal Monarchy of the Stuarts appeared to one shrewd observer, during the period when Charles dispensed with Parliament, to be justifying itself in England by its success, ${ }^{1}$ but the system was inherently unsound; it had no real stability and fell to pieces as soon as it was openly attacked by the Scots. The English Personal Monarchy was a serious attempt to maintain the mediæval tradition, but to render it national, and to organise a polity in which the national life, economic and civil, should have a religious character and in which Christian principles should be supreme; yet it proved to be a failure in practice, for it is impossible to continue to coerce a free people even for their own good. From whatever point of view the system was considered it seemed to be utterly indefensible on grounds of principle.

From the religious standpoint the new system was condemned for reasons that were very similar to those which had been alleged so effectively in regard to the Papacy. The ecclesiastical courts were the special object of attack; they seemed to be a mere travesty of a spiritual authority, since they were quite ineffective in putting down the

${ }^{1}$ Clarendon, History of the Rebellion, I, 159. 


\section{CHRISTIANITY AND POLITICS}

generally admitted disorders of the Church. On the other hand, they took cognisance of all sorts of secular matters, such as the promotion of the fishing trade and the proving of wills. There was ample ground for contending that ecclesiastical discipline had become completely secularised, and that it ought to be brought into closer accord with the religious sentiment; it was urged that this could only be expected if the ecclesiastical tradition were still further modified and brought into closer accord with Scripture. Rites and practices were insisted upon by ecclesiastical authority for which no definite support could be quoted in the written Word, even if they were not actually condemned; whilst scant respect was shown to those who scrupled about the remnants of Popery which had not been purged away.

But the chief ground of offence lay in the fact that the ecclesiastical system was so closely dependent on the Crown. Romanists and Nonconformists alike were concerned to maintain a more : complete spiritual independence, and to insist that the Crown could only have a subordinate place in a Christian polity. The position in regard to national religious life, which had been assumed by the Crown, however it might be safeguarded and explained, was so unsatisfactory to many earnest men of diverse views that they 


\section{CHURCH AND STATE IN ENGLAND}

agreed in rejecting the English Church as lacking in spirituality.

There was also abundant ground for complaint from the point of view of civil and constitutional lawyers. Their jealousy was roused by the conferring of offices on ecclesiastics, as well as by the part they played in the Councils of the Realm. There was grave doubt as to the constitutional character of the Courts of the Star Chamber and of the High Commission; they were represented as fussy and unreasonable, and their practices as inconsistent with recognised English liberties. The law which was enforced in ecclesiastical courts had never been passed by Parliament; and Englishmen might be called upon to answer in regard to alleged offences which were unknown to the law of the land. The records of St. John's parish at Huntingdon show that Oliver Cromwell ${ }^{1}$ was publicly censured and subsequently did public penance; but unfortunately we are left without information as to the faults with which he was charged. There could, however, be no doubt that there were hundreds of respectable people who had some cause for personal resentment when the Long Parliament commenced its attack on the Church.

${ }^{1}$ Oliver Cromwell was publicly censured in church in 1621, and he did public penance in 1628. His precise offence is not noted, but at the latter date Laud was Archdeacon of Huntingdon, and there was a dispute going on about a lectureship. 


\section{CHRISTIANITY AND POLITICS}

The most effective attack on the government was from the economic side. The period of Personal Monarchy under Elizabeth and the Stuarts was a time of very rapid change. Times of rapid change may be periods of great improvement, though serious evils are often incidental to the transition. The government endeavoured to promote improvement, but to restrict it in such a fashion that the incidental evils should be reduced to a minimum. They were thus laid open to criticisms from two points of view. Complaint might be alleged of the hardships which arose through the draining of the Fens and the progress of enclosure, but there was a more general outcry against attempts to regulate progress on the ground that they hampered it unduly. It was constantly said that steps which had been taken by the government to regulate progress and to foster it were not really beneficial, but restricted the natural growth. Foreign commerce was almost entirely in the hands of regulated companies which had obtained concessions for carrying on business at particular points in foreign parts. The Merchant Adventurers, who finally settled at Hamburg, were supposed to regulate the export of cloth to the chief markets of the Continent in such a fashion that there should be a steady development of the sale abroad at remu- 


\section{CHURCH AND STATE IN ENGLAND}

nerative prices. They were meant to be an organ for securing healthy conditions for the manufacture of cloth for export. James I, with his Scottish experience of national trade, had viewed these companies with suspicion; and though they maintained their position, complaints were frequently made, both by the manufacturers whom they were supposed to assist, and by the interlopers and independent traders who were deprived of opportunities for pushing foreign trade.

Still more exception was taken to the granting to patentees of concessions for the exclusive right to manufacture some marketable article of general demand. They were supposed to introduce the best methods, to maintain a high quality in the wares, and to give favourable conditions to the employees. But many grievances were alleged both by the consuming public, and by the rivals who were restricted from entering into competition. At this distance of time it is impossible to judge each case on its merits, and it is at least highly probable that patents were sometimes issued as a method for levying a form of indirect consumption; but a question of principle was involved in regard to economic progress. The Stuarts had aimed at healthy progress and especially at minimising the fluctuations of trade, while the critics took their stand on the principle 


\section{CHRISTIANITY AND POLITICS}

of allowing freedom for the individual to employ his capital in any branch of industry or commerce he preferred. The advocates of unfettered progress won the day, and the capitalist class in the towns, especially in the city of London, were the backbone of the armed resistance to Charles I.

\section{THE RIGHT TO COERCE}

The Personal Monarchy of Elizabeth and the Stuarts was the first attempt to establish a Christian polity on a national basis, and the whole circle of human life was taken into account; there was no attempt to pursue religious or political or economic aims to the exclusion of others. The Crown recognised that these three strands were closely intertwined. In some ways the conditions under which this experiment was made were favourable. It was possible for the Council to work by means of existing and recognised agencies, without creating a new system in Church or State. Conscious efforts were made to maintain old traditions, and it seemed unnecessary to win acceptance for any new theory of political life or social duty. Yet even under these circumstances this national Christian polity was a complete failure; and if we are to learn from experience it is important to take the reasons of that failure to heart. We have consciously entered on a democratic era, 


\section{CHURCH AND STATE IN ENGLAND}

and realise that improvement in Church and State can only be effected through a widely diffused sense of duty and the willing co-operation of the citizens; it cannot be brought about by coercion alone. Coercion may be exercised by a personal monarch who claims the right to rule, as was done by Charles I and his council, and it may be extraordinarily efficient, as it has proved in Germany, where the loyalty of the people has rallied in such an extraordinary degree to support the designs of the Emperor. The right to rule may also be claimed by a triumphant majority, which insists that minorities must suffer and is prepared to enforce its will ruthlessly; but there can be no stability in a community where there is constant submission to superior force and where civil order does not justify itself by public opinion or rest on popular consent. Civil authority is much less likely to commend itself in attempting to promote the common good than in prohibiting and putting down obvious wrong; and the collapse of the monarchy of Charles $I$ is a warning for all time. It may be possible to levy taxes and obtain money for objects which many citizens regard as of doubtful utility, but they will not willingly alter their own habits as to diet, or the management of their own affairs, for reasons which do not commend themselves to their own judgment. They 


\section{CHRISTIANITY AND POLITICS}

are specially sensitive if they believe that the common good is not really involved, but that their interests are being sacrificed to those of more favoured individuals.

The aims of Elizabeth and the Stuarts were for the most part judicious. History has failed to justify their methods, but it has also condemned their opponents. The Nonconformists of the Elizabethan era were deeply attached to Calvinism, they found their inspiration in their belief as to personal predestination to be the instrument of carrying out God's Will here and of sharing in glory hereafter. The unpopularity of the Church of England in religious circles in the early seventeenth century was due, so far as doctrine is concerned, to her unwillingness to accept Calvinism; but in this she was wise. Calvinism in its strict form has been completely outlived; and the Christian denominations, which originally took their stand upon it, are vying with each other in discarding it. The Elizabethan Nonconformists were also inclined to refuse compliance with usages in Christian worship for which no warrant could be found in Holy Writ; they hesitated about lessons from the Apocrypha, the keeping of Christmas Day, and the use of organs; but their descendants have abandoned that principle, and are ready to employ the aids to worship against 


\section{CHURCH AND STATE IN ENGLAND}

which their forefathers protested as a ground of offence.

There was a general agreement in the Elizabethan period that there ought to be a common order of service, and that there should be some safeguard against the vagaries of Anabaptists. But those who agreed on the desirability of a national use differed greatly in regard to the question as to what that common order should be. The compromise which was embodied in the Book of Common Prayer has justified itself as a common order for the nation, both at the time at which it was compiled, and in subsequent centuries as well.

Even in the economic regulation, which caused so much irritation, the critics of the government have been condemned. The granting of concessions to commercial companies was dropped for a time under the Council of State, but the difficulties which ensued were so great that Cromwell revived the practice of authorising such companies. The main lines, by which the Crown had endeavoured to direct economic activities so as to promote the power of the nation, were acted upon by Parliament after the Restoration; and the Council gave much attention to the founding of factories and the planting of new colonies, and thus carried out the schemes for expansion which 


\section{CHRISTIANITY AND POLITICS}

had occupied the attention of James and Charles I. In all these matters it may be fairly claimed that the aims of the Stuart Kings and their advisers were far-seeing, and that their critics were shortsighted and concentrated their attention unwisely on immediate interests.

Modern rulers, who disregard this warning and make fresh attempts to coerce free persons for the common good, would do well to assure themselves that the particular projects at which they aim are really for the common weal and that their action will be recognised as really public-spirited. They have also need to be sure that the agents by whom pressure is brought to bear in any given direction are honest and tactful. If they fail in either respect their schemes are sure to be subjected to criticism, which may be ill-natured and shortsighted, but may yet appeal sufficiently to the popular imagination to render their schemes unworkable and to baulk their endeavours for the public good. A free people can only be led, and can never be successfully driven. It is the art of leadership to convince the people that some scheme of policy is really for the common good, so that they may be willing to comply with it in spite of the sacrifices it may entail. 


\section{III}

\section{PRESBYTERIANISM AND THE SUPREMACY}

OF SCRIPTURE

\section{THE SCRIPTURAL MODEL OF A POLITY}

A generation had passed away after the time when Henry VIII had defied the authority of the Pope (1533) before a similar change occurred in Scotland (1560). The pent-up forces in the Northern Kingdom were very violent when once they were let loose, and a new conception of a reformed Christian polity had taken shape under the guiding hand of John Calvin at Geneva. The Reformation Movement in Scotland was a veritable revolution, since it was a conscious repudiation of the past, and a genuine effort to introduce something that was wholly new.

The aim of King Henry VIII and the English Reformers had been to retain as much as possible of the mediæval tradition of a Christian polity, but yet to build it on a national basis, and to use Scripture as a test which should show what ought to be discarded as unnecessary in a Christian community. But the antagonism to the old order in Scotland was much more intense: there was no 


\section{CHRISTIANITY AND POLITICS}

disposition to recognise that it had any good about it at all; it was repudiated as a mere caricature of what a Christian polity ought to be. The parochial system had not been of such long standing in Scotland as in England, and it never attained the same importance in the religious life of the country. The great monastic establishments had relatively a far greater importance in Scotland than the corresponding institutions in England; and the monastic ideal appeared to be inconsistent with Scripture; indeed the whole ecclesiastical system, with its approval of celibacy and discrimination in regard to abstention from meats, came under St. Paul's condemnation as a doctrine of devils. ${ }^{1}$ The English Reformers complained that the Mediæval Church had failed to realise her ideals; but the Scottish Reformers insisted that the ideals were false and mistaken. The monasteries had been founded for the pursuit of a religious life apart from the world; while the Scottish Reformers demanded that the religious life should be lived in the world, and that religious institutions should thereby render secular activities completely Christian. The Scottish Reformers thanked God who had delivered the kingdom from the superstitions of the Roman Anti-Christ, and enlightened it with the rays of His own light

1 I Tim. IV, 1-3. 


\section{PRESBYTERIANISM AND SCRIPTURE}

(1572). ${ }^{1}$ It was their endeavour to render the breach with the "synagogue of Satan" as complete as possible.

At the same time they held firmly to the ancient aim of establishing and maintaining a Christian polity. This conception had dominated Christian life in Europe since the fall of the pagan Empire; and it came into fresh prominence in the troublous time of the Reformation. The individual reformers and separate congregations felt their helplessness: it was only as organised communities, maintaining their independence of the Papacy and the secular powers it could put in motion, that the reformers could hope to keep alive the light of the gospel in the world. Just as Israel had been a witness for true religion to the world, so the Scottish Reformers were inspired with an enthusiasm for maintaining a national testimony to pure Christianity. The Scottish Estates in 1572 put forward a formal confession of the national faith. "Long have we thirsted," they say in the preface, "dear brethren, to have notified to the "world the sum of that doctrine which we profess, "and for the which we have sustained infamy and "danger: but such has been the rage of Satan "against us and against Christ Jesus His eternal

1 Dunlop, Collections of Confessions of Faith, In, 14. 


\section{CHRISTIANITY AND POLITICS}

"Verity lately now again born among us, that "to this day no time has been granted unto us to "clear our consciences as most gladly we would "have done; for how we have been tossed here"tofore, the most part of Europe, as we suppose, "does understand." 1 They anxiously insisted that Scripture was the supreme standard by which they had been guided and to which they desired to conform in any point where they might have misapprehended it. "We have chief respect to our "weak and infirm brethren, to whom we would "communicate the bottom of our hearts, lest that "they be troubled or carried away by diversity of "rumours, which Satan spreads against us to the "defeating of this our most godly enterprise; pro"testing that if any man will note in this our "confession any article or sentence repugnant to "God's Holy Word, that it would please him of “his gentleness and for Christian charities' sake "to admonish us of the same in writing; and we " upon our honour and fidelity, by God's grace do "promise unto him satisfaction from the mouth "of God, that is from His Holy Scriptures or else "reformation of that which he shall prove to be "amiss." The necessity of the combined action of king and people was further accentuated by the Band of Maintenance in 1588, in which the King,

1 Dunlop, Collection of Confessions, ir, 15. 


\section{PRESBYTERIANISM AND SCRIPTURE}

"the estates and persons of all ranks and degrees "combined themselves, to join and concur with "the whole forces of our friends and favourers, "against whatsoever foreign or intestine powers of "Papists or their partakers, that shall arrive or "arise within this island or any part thereof; . . . "to join and hold hand to the exclusion of what"soever means or order shall be thought meet by "His Majesty and Council for the suppressing of "Papistry, the promotion of true religion, and “settling His Highness' estate and obedience in "all the quarters and corners of this realm: to " expose and hazard our lives, lands, and goods, "and whatsoever means that God has lent us, "in the defence of the said true and Christian re"ligion and of His Majesty's person and estate." 1 The consciousness of a national religion and a national testimony for scriptural truth has sunk very deeply into succeeding generations of the Scottish people.

In endeavouring to carry out this aim John Knox and the Scottish Reformers consciously adopted the model of a Christian polity which had been already established at Geneva. Geneva was a city state and some modification was needed to adapt the institutions of a Christian municipality to a Christian realm. Scottish Presbyterianism

1 Dunlop, Collection of Confessions, II, Band of Maintenance, 109. 


\section{CHRISTIANITY AND POLITICS}

was the outcome of this endeavour to build a scriptural polity, not merely on a municipal, but on a national basis. And as the Presbyterian system took a firmer hold and gradually extended over the whole of Scotland, it did much to supersede tribal organisation and local patriotism and to diffuse and intensify conscious national life. The Scottish Christian polity was an expansion of that of Geneva, as the English national polity professed to be the maintenance, in a smaller sphere and under a new administration, of the institutions of Christendom.

In breaking with the past and endeavouring to institute a purely scriptural polity, it was inevitable that great stress should be laid upon the Old Testament as a source of instruction in the Divine Will for a well-ordered social life. From the New Testament information could be gleaned about Christian organisation and worship as constituted for all times in the Apostolic age; and this was the warrant for ecclesiastical organisation in Kirk Sessions and other ecclesiastical courts, and for the Book of Common Order; but the Church in Apostolic times had no status in the civil society of the time; and the New Testament, although it insists on the personal duty of civil obedience, has little guidance to give about the 


\section{PRESBYTERIANISM AND SCRIPTURE}

constitution of Christian States. The Scottish Reformers traced the analogy between the realm of David and his successors, and that of the Scottish Crown. They looked to the Old Testament as giving an example of a definitely ordered monarchy; and they took it as containing a code of morality, which should be enforced in Christian States for all time. Hence they had little difficulty about matters that had troubled the consciences of many other Christians; they made no scruple in regard to the employment of force by public authority on behalf of the community. They recognised that the magistrate was empowered to inflict corrective punishment by fine and imprisonment or even to enforce the penalty of death on the murderer or witch; they regarded him as God's minister for the punishment of evil doers. The Old Testament was full of instances where the people of God went forth to war; and the Covenanters had scriptural warrant for appealing to the ordeal of battle in defence of their religion, and as a means of diffusing it. This insistence on the continued validity of the Old Testament as a code for Christian times explains the attachment of the Scots to the principle of monarchy, and their quarrel with the Independents and the Army; while, on the other hand, it led to an acceptance of the Jewish morality as 


\section{CHRISTIANITY AND POLITICS}

adequate, and left little incentive for men to attempt to rule their own lives personally in accordance with the higher morality which is distinctive of Christ and His teaching. A polity in which Old Testament morality is accepted and enforced may yet, as the Sermon on the Mount teaches us, be defective from the Christian point of view.

The chief point, in regard to which the current morality in Christian communities during the Middle Ages had advanced beyond that of contemporary Judaism, was in regard to the taking of interest for money lent. The Jews had full scriptural authority for lending money on interest to men of other races than their own, and this permission seemed to show that the taking of interest was not wrong in itself, but only under certain conditions. The feeling against the taking of interest, which is expressed in the Old Testament and which is common to many moralists, had been taken more seriously by Christians. Usury was regarded as a practice which involved a sordid making of gain at another's expense, and which therefore was unchristian. Much careful casuistry was devoted to discriminating between the kinds of bargain by which men might be tempted to place themselves in this unchristian relation 


\section{PRESBYTERIANISM AND SCRIPTURE}

to their neighbours; and the conduct of moneyed men, who entered into hard bargains, was deprecated. In the sixteenth century great difficulty arose in applying the old distinctions, and they seemed to be pedantries. The practical question, which presented itself to the honourable business man, was that of the amount of interest which it was fair to take. It was in this that he saw a possibility of oppression under the changed circumstances of his day. Geneva was a great commercial city, and Calvin with some hesitation refused to condemn the taking of interest as such, and thus opened the way for the lending of money and trading on borrowed capital to be recognised as permissible in a Christian community. ${ }^{1}$ By this decision he did much to reconcile those who were engaged in mercantile callings with Christian morality: it no longer seemed to them pedantic and unpractical; but on the other hand the specific character of Christian teaching in regard to the use of money had disappeared. The Calvinists adopted a standard of honesty which appealed to upright men, whatever faith they might profess; and no serious attempt was made to form a definite public opinion as to Christian duty in the use of the advantages and powers which money gives. Calvin had not put forward any positive doctrine;

${ }^{1}$ Cunningham, Growth of Englisin Industry and Commerce, II, 155. 


\section{CHRISTIANITY AND POLITICS}

but he had undermined the restrictions which had hitherto been placed, from the religious standpoint, on the employment of capital, so that the capitalist now felt free to use his money in the fashion that brought him most personal gain.

The most remarkable feature of the new polity was the reassertion of spiritual independence, and the consequent claim of the supremacy of spiritual authorities over the civil powers. The ministers took the attitude of Nathan and the Hebrew prophets towards David and the Jewish kings. James VI was reminded that he was only "God's "silly vassal," while the ministers were the interpreters and spokesmen of the Word of God. Their office gave them an authority, in interpreting the Divine Will, which no secular power had a right to assume. This was an essential element in the system. The supremacy of the Bible implied the supremacy of those who were its recognised interpreters. This claim gave rise to strained relations in Geneva between Calvin and Beza on the one hand and the municipal authorities on the other: in Scotland it found expression in the national Covenant. To Englishmen generally it was an intense surprise to find that the claim of spiritual independence for the ministers was maintained as strenuously by sixteenth century Presby- 


\section{PRESBYTERIANISM AND SCRIPTURE}

terians as by the adherents of the Roman See. The limitations of Scottish loyalty to the Crown, and the readiness of the Scots to take up arms against the Crown were to them incomprehensible; while after the Restoration, the conscious objection of the Covenanters to recognise an uncovenanted king rendered them under suspicion of possible treason, in the same way as this suspicion attached to the Jesuits and thorough-going Papists. The suspicion may have been wholly unjustified and the action to which it gave rise is deeply to be regretted; but we need not on that account ignore the reasons which led responsible authorities to employ the methods of barbarism in trying to stamp out a subtle danger to the community. Nor was this claim allowed to be forgotten: the principle of spiritual independence was asserted by many acts of resistance to the alleged encroachments of civil authority before the disruption of the Scottish Church in $1843 .{ }^{1}$

\section{PRESBYTERIAN THEOCRACY}

The critics of the ecclesiastical system in England were much dissatisfied with the laxity of the spiritual discipline which was exercised in the ecclesiastical courts, but this complaint could

1 G. W. T. Omond, The Lord Advocates of Scotland, 64 and 68, end Series. 


\section{CHRISTIANITY AND POLITICS}

not be made against the discipline by Kirk Sessions, Presbyteries, and Synods which were erected in Scotland. The function which these courts sought to discharge was that of preserving the Christian polity from scandal. Anything which contaminated the religious life of the community marred its effectiveness as a testimony to the world. Since the celebration of Mass had come to be regarded as a blasphemous travesty of Christian rites and a sinful act of idolatry, the Reformers felt that they could not tolerate it even as an exception, without tainting the life of the whole community. On similar grounds they felt that they were lacking as a community in respect to the ordinances of God if they suffered a witch to live. The strictness of the Jewish Code in maintaining the sanctity of the Sabbath was regarded as an injunction for all time as to the manner in which the Lord's Day should be respected; and strenuous efforts were made to prevent the scandal of desecration. Frequent Acts of Assembly were passed against promiscuous dancing and liberty of conduct which were unseemly in a godly community; and every effort was made to put evildoers to public shame, as a means of maintaining the standard of conduct which should be expected from Christian men. The successful enforcement of an external code led to the forma- 


\section{PRESBYTERIANISM AND SCRIPTURE}

tion of very definite habits of mind in regard to Christian duty; but it left room, as there had been in the time of Our Lord, for formal compliance with an external standard apart from any deep sense of personal duty.

Just because there was in Scotland such a strong sense of Christian life as organised in a community, there was also a widespread recognition of the duties of the community; and certain activities, which were left in England to be dealt with in a more haphazard fashion, were systematically organised as obligations to be discharged out of ecclesiastical resources.

Of these the most important was the system of parochial schools; a good deal had been done for popular education in the sixteenth century by some of the Scottish Bishops; but it was owing to John Knox that provision was made, out of the remnants of Church property, which were rescued from private hands at the Reformation, for establishing a school in every parish. The education which was thus given was definitely religious in character, and it was designed to fit the child for all the duties of life here, and as a preparation for life hereafter. It was not till the nineteenth century that the duty of the community as a whole towards the up-bringing of children was so gener- 


\section{CHRISTIANITY AND POLITICS}

ally recognised in England, and then it was undertaken partly by localities independently, and partly by voluntary societies, though these efforts were at first supplemented and subsequently directed and controlled by the State.

The Christian duty of relieving the aged and the impotent poor was also systematically organised and not left to individual tender-heartedness. The collections at church doors supplied the funds, which were applied to this purpose, and continued to be regarded as sufficient till the time of the Industrial Revolution, though in some cases it was found necessary to augment the collections by means of assessment. The power to assess was given by an Act ${ }^{1}$ of James VI, but a hundred and twenty years later there were only three parishes where these powers had been brought into operation, and the number had risen to about ninety in $1800 ;{ }^{2}$ throughout the country generally the church collections sufficed, till the whole system was hastily condemned and swept away in 1845. ${ }^{3}$ These funds were administered by the parochial ministers and elders, though in some towns, where more than one parish had been created, the practice was adopted of administration

1 Acts of Parliament of Scotland, 1579, c. 12.

2 Omond, op. cit., 133.

3 Ibid., op. cit., 133-44. 


\section{PRESBYTERIANISM AND SCRIPTURE}

by the magistrates. ${ }^{1}$ The lines on which relief was given were very similar to those which are advocated by Charity Organisation Societies in the present day. It was the main principle to refuse relief to the undeserving, and thus if possible to force the pauperised to become useful members of society. Dr. Chalmers and the other advocates of retaining the Scottish system pointed to the pauperising effect of the Poor Law as administered in England, and were anxious that their own country should be kept free from the "moral lep"rosy" " 2 which the system engendered. On the other hand, there was a widespread sense that the Scottish parochial relief was inadequate, so that hardship was inflicted on the deserving poor; and at the time of the Industrial Revolution the Scottish system seemed quite ineffective for dealing with the masses of the population who were congregated in great towns. Carlyle spoke of the conditions which had grown up as "a "moral gangrene," and insisted that "Scotland "must have a Poor Law if Scotland is not to "be a by-word among the nations." 3 It need

1 The city of Edinburgh formed one parish before the Reformation, but it was divided up into four parishes shortly afterwards. The Church which had been used by Franciscans became a Parish Church and the Collegiate Church of Holy Trinity another.

2 Chalmers' Political Economy, 5.

8 Past and Present, i, i. 


\section{CHRISTIANITY AND POLITICS}

cause no surprise that the advocates for dealing with the problem on the lines which had been adopted in the recently reformed Poor Law in England, should have gained the day; but it is a matter of interest that the systematic organisation of Poor Relief as a Christian duty should have been successfully carried on for so long and that such a weight of evidence was adduced as to the possibility of adapting it to the requirements of society in the middle of the nineteenth century. ${ }^{1}$

There was, however, one serious disadvantage in connection with the Scottish system; it left little scope for the exercise of personal charity to poor neighbours. Suspicion was rife that many of the benefactions which had been made in mediæval times were due to superstitious motives and a readiness to try and compound every sin which weighed upon the conscience by monetary gifts to the Church or to the poor. "Alms-giving is papistry" - is a terse expression which embodies a feeling that was widely diffused; and if, as was generally supposed, the Ministers and Elders provided for all the deserving poor, there could be no Christian duty to encourage the

1 The great assertion of the principle of spiritual independence and the consequent division of the Scottish Church by the Disruption in 1843 was at least one of the reasons which made it impossible to carry out the necessary changes in the system of parochial relief. 


\section{PRESBYTERIANISM AND SCRIPTURE}

undeserving in their idleness. The Christian conscience was satisfied with organised Christian action and was not stimulated to supplement it; and there is little sign in Scotland of the foundation of parochial charities, such as were established in such numbers in England during the seventeenth century. The great merchants or tradesmen left money for the decayed members of their own company or trade, or for hospitals in a town, but it is not easy to trace benefactions for the poor of a parish. The most important Edinburgh charity of that date was founded by George Heriot, a Scottish goldsmith, who had settled in London, and his plans were carried out after his death through the agency of the Dean of Rochester.

The ministers were ready to take their part in advocating conduct that should be for the material welfare of the community; but the circumstances of Scotland were very different from those of England, and the duties which were demanded of the good citizen were quite distinct in the two countries. Scottish trade was hampered by the efforts of the Stuart Kings to carry out one policy for both the realms. ${ }^{1}$ Scottish trade interests had been distinct from those of England, and serious loss occurred when they were subordinated to the

1 T. Keith, Commercial Relations of England and Scotland, 16. 


\section{CHRISTIANITY AND POLITICS}

policy which suited the sovereign of the kingdom. It was impossible to regard the Crown as the guardian of the material interests of the Northern Kingdom, and loyalty to the Crown was not a duty which appealed to the patriotism of Scottish merchants. The interests of a King of Great Britain, and of Scotland as a community, were distinct. On the whole, too, Scotland was standing on the defensive and endeavouring to hold its own, not only against the continental monarchies but against submission to English institutions. The country had neither the opportunity nor the resources for making considerable attempts at plantation in the New World, and hence the sense of mission through national expansion was undeveloped. The chief need of the Scottish nation was the development of Scottish resources, and the formation and investment of capital so as to give employment to the poor. Those who used their means in this way were regarded as not only contributing directly to the public good, but as exercising the virtue of charity in the wisest way. The man who uses his wealth to employ labour is providing relief for the poor in a form in which they can receive it with self-respect. At the time of the Lancashire cotton famine, John Bright, instead of contributing to the relief funds, kept his works going at an enormous loss, since this was 


\section{PRESBYTERIANISM AND SCRIPTURE}

the way in which he believed he could do most to prevent and relieve distress. This principle was clearly recognised in Scotland, and hence it came to be felt that the capitalist who employed labour was fulfilling his duty of promoting the welfare of the community. The possibility of a conflict between public and private interest in matters of industry and trade had so far fallen into the background that it was no longer regarded as a practical thing of which account had to be taken.

The duty of the citizen seemed to lie in the cultiration of the prudential virtues of diligence in business, and avoidance of waste and idleness as the fruitful cause of $\sin$. This closely reflects the sense of duty portrayed in the Book of Proverbs, and the Presbyterians were satisfied to enjoin these Old Testament virtues.

There were, however, serious defects in this conception of morality, and these came out in the long run. The Pope's laws, which had endeavoured to guard against the extortionate use of capital, were waived aside as pedantic and superstitious restrictions; and the welfare of the community was not conceived in such a form that the enterprising and industrious citizen was likely to do it any injury. The private conscience of the most 


\section{CHRISTIANITY AND POLITICS}

scrupulous man was likely to be satisfied if he felt that in the use he was making of his capital he was promoting the welfare of the community, while incidentally he received private gain. Neither from the religious nor from the political side was there any encouragement or help to the religious man to consider carefully whether his capital was being employed in such a fashion as to be oppressive or extortionate. Calvin's doctrine had tended in favor of free play for capital; and free play for capital appeared to justify itself, in the conditions of Scotland in the seventeenth century, as an excellent method of bringing about the public good.

The attitude of mind which was current in Presbyterian Scotland in the seventeenth century is illustrated by the institutions which grew up during that period. Capital was much needed for the development of Scottish resources, and every encouragement was given so as to enable those who were willing to undertake the risk of extractive industry, to secure a permanent supply of labour. Under the encouragement given by the State in a Christian community, a new species of slavery grew up, which involved very serious disabilities both as to freedom of movement and legal status. By an act of $1606^{1}$ masters of all collieries and of

1 Statute 1606, c. 10. 


\section{PRESBYTERIANISM AND SCRIPTURE}

salt pans "were permitted to apprehend all vaga"bonds and sturdy beggars to be put to labour," and these were not allowed to be hired to other employment so long as this master required their services. In 1672 these powers were extended to "others who have manufactures ${ }^{1}$ in the king"dom" so that they were able to "seize upon any "vagabonds or beggars wherever they could find " them." These employers had the same power to correct their labourers and to enjoy the benefit of their work in the same way as those who held the position of Master of a House of Correction. The growth of a form of capitalist slavery in Scotland was all the more remarkable as feudal serfdom had disappeared in that country at a very early date; though the new slavery gave an excuse for our unsuccessful attempt to revive the old serfdom. ${ }^{2}$ The latest known attempt to establish a

1 Statute 1672, c. 11.

2 There was an attempt at the end of the seventeenth century to treat certain fishermen in the north of Scotland as serfs. Reid, Beverage and some fishermen upon Don having entered into a tack with the Laird of Woodney, they were also claimed by Forbes of Foveran on this ground that they were born on his land, and so were as much glebce addicti, and astricted to live there, as colliers and salters. (31 July, 1696.) Foveran contended that they were born on his ground and by the "custom of the coast side were glebce adscripti, and could not hire themselves to another without his consent, no more than colliers and salters may do. Answered, Esto they were astricted, yet it is a contract ex una parte obligatorius, and if you want a boat, then $I$ am free to go and serve where I please, and it is a direct manumission from the servitude when you have no work to give me. And colliers are tied by an express statute, whereas there is none 


\section{CHRISTIANITY AND POLITICS}

claim to a serf in the Scottish Court occurred in $1364 ;{ }^{1}$ so that mediæval serfdom appears to have died out in Scotland nearly twenty years before the grievances of the peasants led to a widespread revolt in England in 1381. Sir George MacKenzie in his Institutes (1694, p. 50) claims that the title of slavery in the Civil Law has no application for Scotland, and in the same connection Lord Stair (1681, p. 21) contrasts the immunity of Scotland with the vestiges of serfdom which had so long survived in England; but at the very time when these lawyers were writing, this new form of capitalist slavery was growing up under their very eyes. The Habeas Corpus Act of $1701^{2}$ especially excepted the colliers and salters from protection against "wrongeous" imprisonment. Forbes writing of the law of Scotland in 1722 explains that "servants are either slaves or hirelings or appren"tices. Slaves are those who are at the arbitrary "pleasure of their master, and may be sold by him "as his goods. We have no vestige of slavery re-

in this case." These fishers had been many years out of Foveran's service, because he kept no boat. The Lords finding that there was no law astricting fishers to the ground where they were born, and that the custom was not general, but only in particular places, they condemned it "as a corruptela and unlaw, and tending to introduce slavery contrary to the principles of the Christian Religion and the mildness of our government" (16 Feb., 1698). Sir J. Lauder of Fontainhall's Decisions, 1678-1712.

1 Innes, Scotch Legal Antiquities, 159.

2 Acts 1701, c. 6. 


\section{PRESBYTERIANISM AND SCRIPTURE}

"maining in Scotland, except in coal-hewers and "salt-makers, who having once been employed to "work in coal pits or salt houses by the coal or salt "master are by law, without any express action, in"thralled or astricted, during their life, to perform "these services to him; and may be recovered by "him from any unlawful possessor, to whom they "unwarrantably revolt from their master's serv"ice. These, if challenged within a year, the pos"sessor must deliver back to their master within "twenty-four hours, under pain of $£ 100$ Scots. to "be paid to him. Coal and salt masters are also "empowered to apprehend and set to work vaga"bonds and sturdy beggars; but are not allowed "to give to coal-hewers more than twenty merks "money foresaid in fee or bounty; and these and "other workmen in coal-pits and salt-houses "must labour all the six days of the week upon "pain of $20 \mathrm{sh}$. per diem, to be paid to their mas"ter, beside corporal punishment, and making "up his prejudice." 1 It took two acts of the Parliament of Great Britain to break down the new slavery which had grown up in Presbyterian Scotland during the seventeenth century. ${ }^{2}$ If anyone cares to follow the matter further and considers the treatment which was laid down for

1 Professor W. Forbes, Institutes of the Law of Scotland, I, 73.

215 Geo. III, c. 28 , and 39 Geo. III, c. 56. 


\section{CHRISTIANITY AND POLITICS}

hirelings and apprentices, he will perhaps feel that it was not marked by any excessive humanitarianism.

The relief of the impotent poor was attended to by the ministers and elders, but the occasional insight which we get as to the treatment which was meted out to the able-bodied beggars shows that they were regarded as a danger to the community and as persons who ought to be punished. There is no sign of any inkling of the possibility that they were unemployed through no fault of their own, or of any hope of winning them back to a better mode of life except by severity. The municipal authorities were chiefly concerned in this matter. By an order of the Town Council of Banff in $1642^{1}$ beggars were to be put in the "Thief's "Hole" till the magistrates get convenient time to "scourge them in the most rigorous manner without any pity." In 1673 houses of correction were set at a number of different centres in the country, and a very rigid discipline was introduced among those who had been caught begging, and were sent to these establishments. The punitive treatment of the poor was very noticeable in Scotland, but there is very little evidence of preventive legislation, by providing stocks of material for setting the poor to work.

1 W. Watt, Aberdeenshire, 207. 


\section{PRESBYTERIANISM AND SCRIPTURE}

\section{THE DANGER OF MISUSING SCRIPTURE}

The Bible was at once the foundation, the textbook, and the inspiration of the Presbyterian theocracy, and yet it was a social system which proved very one-sided and failed to provide against the injustice towards labour which has come to light in modern society. Attention was directed to the good of society; and the individual, except as he contributed to the good of society, was hardly taken into account. The capitalist system brought the forces of progress to bear, so as to promote the material welfare of the polity; Calvinism, recognising the importance of capital as a factor in the welfare of the community, allowed it to have free play, and thus gave a religious sanction to these forces of progress, without considering the incidental suffering that might arise in the onward march of progress. Those who took an active part in promoting the material wealth of the community were regarded as public benefactors who were doing their duty to society; while those who failed to keep pace or to hold their own in the struggle for existence were regarded as encumbrances, and when they were able-bodied were blamed rather than pitied. The religious approval, which has thus been given to men who practised the prudential virtues with success, and who re- 


\section{CHRISTIANITY AND POLITICS}

ceived an ample reward for the services they rendered to the public, is responsible for the strong impression which exists in many quarters that modern Christianity is on the side of the rich and takes little thought for the needs of the poor. Calvinism by its failure to recognise that there was any need to try to control industrial capitalism, had laid itself open to this charge.

Richard Baxter, who may be regarded as a typical exponent of Presbyterian morality as it was imported into England, has little to say about the danger of entering into hard bargains, but is satisfied that the market rate is a fair rate; he does indeed recommend that land should be let for less than its market value to poor men, ${ }^{1}$ but he seems to have no fear that extortion may be practised by the rich employer; and he certainly gives no guidance to those who might wish to do the fair thing in industrial and commercial life. Even at the beginning of the nineteenth century there was no inclination to impute any blame to the capitalist for the evils that had emerged under a system of free competition. Thomas Chalmers' enthusiasm for social reform was yet compatible with acceptance of laissez-faire; he held that the mischief that had arisen was directly due to improvident marriages among the poor,

1 Christian Directory, iv, p. 137. 


\section{PRESBYTERIANISM AND SCRIPTURE}

and he hoped that Christian agencies, if more widely diffused, would act successfully as a moral restraint, and thus bring about an improved material condition; but even with the shocking misery which surrounded him at the close of the first quarter of the nineteenth century he had no suspicion that any authoritative check need be put upon the working of the capitalist system so as to introduce better conditions of work and better conditions of life. He explains "how roughly a population can bear to be han"dled, both by adverse seasons and by vicissi"tudes of trade - and how, after all, there is a "stability about a people's means which will keep "its ground against many shocks, and amidst "many fluctuations. It is," he proceeds, "a mys"tery and a marvel to many an observer, how "the seemingly frail and precarious interest of "the labouring classes should, after all, have the "stamina of such endurance, as to weather the "most fearful reverses both of commerce and of "the seasons; and that, somehow or other, you " find, after an interval of gloomy suffering and "still gloomier fears, that the families do emerge "again into the same state of sufficiency as before. "We know not a fitter study for the philanthro"pist, than the workings of that mechanism by "which a process so gratifying is caused, or in 


\section{CHRISTIANITY AND POLITICS}

"which he will find greater reason to admire the " exquisite skill of those various adaptations, that " must be referred to the providence of Him who "framed society, and suited so wisely to each "other the elements whereof it is composed." 1 He finds "a counterpoise to the laws of nature in "what may be termed the laws of political econ"omy." 2

The defects in the Calvinistic social system were not due to the short-sightedness of a particular generation, but were inherent in the system itself. It rested on a misapprehension of the nature of Christian morality; in the Old Testament the constitution of a Divine Theocracy was put in the forefront, but it was a mistake to suppose that in the great principles to which Old Testament prophets appealed, "the laws of social welfare are "for all time enunciated; and further that these "laws are as irrefragable and their issues as inevi"table as are such scientific laws as those which "govern the motion of bodies, and as laws of light "or heat or electricity." 3 It is difficult to see how any spiritual influence could be brought to bear directly on such a mechanism, and we should strive to advance from the Old Testament view of an ex-

${ }_{1}$ Chalmers, The Christian and Civic Economy of Large Towns, III, 36-7.

2 Ibid., III, p. 38.

3 W. E. Chadwick, The Church, the State, and the Poor, 90. 


\section{PRESBYTERIANISM AND SCRIPTURE}

ternal code for society to the teaching by which it was superseded in the Sermon on the Mount. Our Lord does not lay down additional statutes for a code which was to be enforced from without, but lays stress on the importance of personal motives and the incentive afforded by personal aspiration. Principles are laid down by which the citizen of the Kingdom of Heaven may become more worthy of his citizenship. It is always true that societies and individuals react upon one another. The Old Testament method recognised the importance of a theocracy as forming the habits of God-fearing individuals, but there is also another side. The increase of personal virtue reacts upon society, personal effort may be the means of initiating and carrying through legislative improvements. Individuals can mould the society of which they form a part, and Christianity supplements Old Testament teaching by maintaining that it is through the devotion and earnestness of individuals that the regeneration of society may be accomplished. 


\section{IV}

\section{INDEPENDENTS AND THE SUPREMACY OF CONSCIENCE}

\section{PERSONAL CONVICTION AND GATHERED CHURCHES}

The Independents, whose principles had been occasionally asserted during the reigns of Elizabeth and the Stuarts, came to the front during the Interregnum. They altogether rejected any system of National Christianity, and insisted on the supremacy of personal conviction as the basis of all true Church life. Instead of putting Christian society in the forefront and thinking of the individual character as formed and moulded by this environment, they regarded the individuals as the constituent elements who associated themselves into a religious society. Browne maintained that "the Church planted or gathered is a company or "number of Christians or believers, which by a "willing covenant made with their God, are under "the government of God and Christ, and keep His "laws in one holy communion; because Christ "hath redeemed them unto holiness and happi"ness for ever, from which they were fallen by the 


\section{INDEPENDENTS AND CONSCIENCE}

"sin of Adam." 1 Such persons constituted themselves a Church "by a public willing covenant "made with God and with each other." The adherents of this view of the nature of a Church believed that they were justified by the description given in the Acts, of the organisation of the primitive churches in Apostolic times; but it is difficult to see that their conception of a Church was in accordance with other parts of the New Testament. "Congregationalism," as Dexter claims, "is "pre-eminently the polity of perfect men, and it "cannot do its perfect work until there be perfect "men"; ${ }^{2}$ but the work of Christ's Church, as Our Lord seems to have anticipated it, was to be done through the agency of imperfect men living in an evil world and leavening it. The separate "gathered" Churches might have fraternal relations but little cohesion, and it is difficult to think of them in the Pauline phrase as forming one body. At any rate the principles of the Independents, whether sound or not, brought them into antagonism with existing parties; they rejected the Theocracy which the Presbyterians advocated as scriptural, while they also denounced the hierarchy which was maintained in the Church of England. To them the very idea of a National Church seemed

1 Browne, Book which Sheweth, etc., Def. 35. Quoted in Dexter, Congregationalism, 105.

2 Dexter, Congregationalism, 694. 


\section{CHRISTIANITY AND POLITICS}

almost a contradiction in terms: "it was un"scriptural in essence because it included the "entire baptised population."1

The question of local organisation gave occasion for the conflict, between the Independents and the adherents of National Christianity, to break out most fiercely. To the English Churchman, as well as to the Scottish Presbyterian, the parish was the local organ by which the national religious life was maintained. Independents were repelled by "the laxness, the corruption, the prac"tical ungodliness of those parish assemblies of "all sorts of persons which were the only Churches "that the Church of England knew. Not merely "the worldliest, and the most selfish and greedy "people, but unbelievers and those of scandalous "lives, might legally, if in point of fact they did not "habitually, partake of the Lord's Supper, with"out protest, or distinction, side by side with the "very elect and anointed of God." 2 Browne, the best known of the Elizabethan Independents, felt that the parochial system of the Church of England was so corrupt that it was a duty for Christian men to withdraw from it and gather themselves into Churches which should be really pure. " Therefore thus sayeth the Lord," he writes, "I "feed not my flock at Paul's Cross in London, or

1 Dexter, Congregationalism, 57.

${ }^{2}$ Ibid., 97. 


\section{INDEPENDENTS AND CONSCIENCE}

“St. Mary's in Cambridge, or in your English Par"ishes. O ye my sheep go ye not hither as though "there were my fold, and there I rested and feed "my flock; for there be shepherds and flocks also "that follow thee, which are not of Christ, for they "hold of Antichrist." 1

These principles were subversive of the very conception of a Christian polity as it had been hitherto understood. The Christian community, as Independents believed, existed for spiritual purposes, and held aloof, so far as might be, from civil affairs; these should be left to the magistrates to be dealt with according to natural principles of right and wrong. The conscious analogy with the primitive Church in heathen cities was pressed; and the thought of the Christian magistrate, as ordained by God to administer civil affairs in a Christian polity, lost practical importance. For them life was divided into two spheres; and it lay outside the scope of the Church, as a Church, to give instruction in regard to social and political duty in the world; the civil order was treated as a thing indifferent, and the Christian principle could hardly be brought to bear either on duties to the community, or on the duties of the community. Indeed, from this point of view

1 Dexter, Congregationalism, $99 n$. 


\section{CHRISTIANITY AND POLITICS}

the whole of secular government was reduced to little more than the furtherance of the interests of the community; but it was difficult to maintain this position consistently. The New Englanders regarded themselves as bound in self-defence to engage in wars which might ultimately give their communities the opportunities of growing and flourishing in peace, while the Independents found it impossible to refrain from authoritative interference with the religious institutions of the country. During the Interregnum an opportunity arose for endeavouring to attack the parochial system and to substitute a method of propagating what they regarded as a thoroughly reformed Christianity; and the civil power was invoked for this purpose. Cromwell's institution of Triers, acting under the authority of majorsgeneral, was part of this scheme; but modern Congregationalists looked back on this alliance with the State as a temporary falling away from the true principles of Congregationalism. ${ }^{1}$

The scheme for abolishing the parochial system was carried out most completely in South Wales. Within a month of the execution of Charles I, the House of Commons passed an Act ${ }^{2}$ which

1 Dexter, Congregationalism, 708.

2 Walker, Sufferings of the Clergy, 149. 


\section{INDEPENDENTS AND CONSCIENCE}

appointed commissioners to receive all the rents of glebes and tithes, etc., of all parishes that were vacant and of all the parishes from which the clergy should be ejected. Three hundred or more livings in South Wales passed into their hands, and they thus received an income of something like $£ 9000$ a year, of which it was difficult to get the commissioners to render any account. ${ }^{1}$

The efforts of the itinerant preachers who were appointed by the commissioners to preach and plant congregations in Wales seemed to be very ineffective as a substitute for the ministrations of the resident clergy. Baxter ${ }^{2}$ notes that they "set " up a few itinerant preachers, who were for num"bers, incompetent for so great a charge; there "being but one to many of those wide parishes so "that the people having a sermon but once in many "weeks, and nothing else in the meantime, were "ready to turn Papists or anything else." According to another account the people had neither "the comfort of preaching, nor praying, nor sacra"ments, nor visiting the sick, nor of any decency "of burial." Even preaching was infrequent, so that the "churches were in most places shut up, "and the fabric thereof ready to fall to the ground "for want of repair." 3

1 Walker, op. cit., 168.

2 Abridgement, 67.

3 Petition (1651), 2; quoted by Walker, op. cit., 163. 


\section{CHRISTIANITY AND POLITICS}

The indignation which was roused by this attempt to divert parochial endowments to the purposes of State, and to substitute an itinerant ministry for resident parochial clergy, was bitterly resented both by English Churchmen and Presbyterians; and a petition, by about fifteen thousand hands, was presented to the Commons on March 16, 1651, which complained of the great number of ministers that had been ejected, the foul and shameful neglect of supplying their places by any competent number of teachers, the vast revenues of the sequestered livings, and the miserable state and condition into which that country was reduced. ${ }^{1}$ But in spite of the resentment that was caused by this new policy in regard to the religious life of the country, there is evidence of an intention to push forward the abolition of parochial ministers and the substitution of occasional stipendiary preachers in other parts of the country. An Act appears to have been passed for carrying out a similar scheme in Northumberland, Cumberland, Westmoreland and Durham; ${ }^{2}$ and in Cromwell's Little Parliament the proposal to put down all the parish ministers in England ${ }^{3}$ was mooted and only defeated by a very small majority. These proceedings go far to explain the violence of the reaction
1 Walker, op. cit., 167.
2 Ibid., 150.
3 Ibid., 68. 


\section{INDEPENDENTS AND CONSCIENCE}

at the Restoration in favour of maintaining and enforcing the parochial system by means of the Clarendon Code. The triumph of Independency had meant the entire disintegration of National Christianity, as hitherto maintained, both by the Episcopal and Presbyterian Churches.

The attack upon the parochial system has been revived in a more acute form in the controversy in regard to the disendowment of the Welsh Church; though the facilities, which are now open for maintaining separate congregations, are very different from those which existed in the seventeenth century, and there is not the same danger of entire spiritual neglect as there was two hundred and fifty years ago. One difficulty which is felt not only in Wales, but all over England, in connection with the parochial system lies in the arrangements for decent and Christian burial. Till recently, those who were buried in churchyards in England were not free to refuse the funeral rites of the English Church. In some cases Dissenters provided burial grounds of their own, and very generally they felt it to be a grievance that they should pay rates for churchyards where services with which they did not sympathise were obligatory. This grievance was redressed in 1868; but since that time there has been fresh cause for local discontent, since dissenters have now 


\section{CHRISTIANITY AND POLITICS}

a right to the use of parochial burying grounds, while many of them feel no moral obligation to assist in maintaining them or providing additional ground when it is needed. The estrangement between Church and Dissent in many localities in England has arisen and been maintained by the feeling on the part of churchmen that dissenters are lacking in local public spirit.

II. ADMINISTRATIVE DUTIES AND THE SOCIETY OF FRIENDS

The Independents had put forward the supremacy of the individual conscience in such a fashion as to bring themselves into conscious conflict with the national life of England, as organised for religious purposes; but George Fox and the Friends went a step further; their sense of personal duty brought them into conflict with the organisation of national life for civil purposes as well. They were not only, as we know them in the present day, ready to protest against national action in appealing to the ordeal of war, but they were keen critics of those who undertook administrative duties and carried on the business of civil government. To most men it appeared, that the official acts of an organised community were not to be judged by the standard that applied to the individual. The private person ought not 


\section{INDEPENDENTS AND CONSCIENCE}

to treat his neighbour with violence, except in selfdefence; but the magistrate, who is placed in a public position, has a right to bear a sword and bring force to bear on any wrongdoer. Again, the civil magistrate is justified in exacting a solemn oath in order to secure reliable evidence as to the guilt or innocence of any accused party; to ordinary common sense it seems justifiable to take life as the punishment of a crime, and it is allowable to organise armed resistance to an attack of foreign enemies or to maintain the cause of the Prince against foreign foes. But the conscientious Quaker refused to recognise this political morality; for him the conscience of the individual Christian man was absolute, and official position did not justify any man in conduct which was not permissible for the Christian man in his private capacity; hence the Quaker condemned much that seemed essential to the very existence of a Christian polity. He did not recognise that the community had rights and duties of its own, which were distinct from those of the private citizen, and thus his religious views not only placed him in a position in which it was difficult to assimilate him to the life of the community, but his atomic doctrine of the State made him something of a positive danger, as anarchists are regarded in the present day. Nothing seems more strange at first 


\section{CHRISTIANITY AND POLITICS}

sight than the bitter persecution to which Quakers were exposed under one régime after another, especially as there is much to be said for their position on purely scriptural grounds. Just as the Presbyterians endeavoured to create a polity that should be in complete accordance with the Bible as a whole, including the Divine ordinances for the Old Testament monarchy, so the Quakers endeavoured to treat the New Testament alone as a sufficient guide in all the affairs of life. In Apostolic times and under a heathen empire the conception of a Christian polity had not arisen, and there was little opportunity for the Christian man to take part in administrative duties or public life. The question of Christian conduct in public affairs could not come up till Christian teaching had secured some dominance over those who were called to rule; but the attitude towards public life, which was current among Christian men in the first century, was no longer appropriate for dealing with the problems which Englishmen had to face in the seventeenth.

The Quaker, as a Christian man, felt compelled to decline the ordinary duties of citizenship; he would not give evidence in the accustomed fashion and he refused to be a party to the use of might in the defence of right. It is difficult to speak in general terms of such a body as 


\section{INDEPENDENTS AND CONSCIENCE}

the Quakers who did not formulate principles to which they all adhered, but were merely friends who had similar opinions; they were not actively hostile to the very existence of civil government in the way that Anabaptists were, rightly or wrongly, accused of being; but they took one Christian standard as applying to personal conduct in every capacity, and regarded swearing in court as profanity, and killing in battle as murder. By giving an undue extension to the maxims of the Sermon on the Mount in their literal application they diverted attention from the Christian duty of exorcising the spirit of bitterness from the heart, while on the other hand they condemned the attitude which had been taken by Christian men towards war in all previous ages. ${ }^{1}$

In regard to many of the duties of citizenship no conflict would arise. George Fox exhorted the justices near Mansfield not to be oppressive in assessing the wages of hired servants. ${ }^{2}$ Penn stood upon the rights, manorial and other, conferred upon him by royal patent in the settlement of Pennsylvania. ${ }^{3}$ In such matters it was possible to press for private rights, and it was natural that conduct should be judged by the standards that

1 See Appendix on the Attitude of the Church towards War.

2 Cunningham, Growth of English Industry and Commerce, Ir, 44.

3 The Welsh Settlers complained that his treatment was ungenerous. C. H. Browning, Welsh Settlements of Pennsylvania, 334. 


\section{CHRISTIANITY AND POLITICS}

were applicable to private men. The whole attitude of the Quakers assumed the existence of a framework of society, but they refused to admit that the maintenance of that framework justified conduct which was not permissible in private affairs. These Friends were endeavouring to order their lives by a Christian standard; they were punctilious in refraining from ostentatious dress, and in using simplicity in speech. ${ }^{1}$ They were not in a position to undertake public duties themselves, and they were severe critics of the manner in which official authority was exercised by others. They set up a sort of new religious code, which condemned certain acts as wrong in themselves apart from any consideration of circumstances; and thus they obscured the fact that the rightness and wrongness of conduct is to be considered according to circumstances and that the motives which had been at work make a difference in regard to guilt and innocence.

The Quaker point of view is simple and plausible; it has been revived in the writings of such a man as Tolstoy, and it has found a congenial soil in the great body of Nonconformists. While specially scrupulous in regard to the duties of private men, they have not shown themselves keenly alive to the duty of the nation as a whole,

1 J. J. Fox, Society of Friends, 69-94. 


\section{INDEPENDENTS AND CONSCIENCE}

or the importance of organised action. The practical difference between those who do, and those who do not regard the community as a body which has a responsibility to God, comes out at times of national crisis. Men who feel that a nation, which fails to use its power to defend a weak neighbour, or to maintain an engagement, if necessary by force of arms, is guilty of criminal neglect, are ready to do their utmost to save their country from falling into this shame and dishonour. Reluctance to join the army is one sign of lukewarmness in regard to the duties of the community. ${ }^{1}$ Members of denominations which do not recognise the religious aspect of national life are tempted to plead their own private opinions as an excuse for declining to take a part in a national struggle. In Wales, where for political purposes Nonconformity is dominant, the members of Free Churches have contributed a very small proportion of Welshmen who have rallied to the call to arms; while the strike of the Welsh miners, whatever their grievances may be, shows that they are not keenly appreciative of any duty to the community. Insistence on the rights of the individual

1 The percentage of the various denominations in the Army is given in a report of the Army Council (November, 1914), Church of England, 70 per cent.; Roman Catholics, 14 per cent.; Presbyterians, 7 per cent., and Wesleyans, 4 per cent. On the other hand the Baptists and Congregationalists furnish 1.2 between them, other Protestants 6 per cent., and Jews .08; and of course there are no Quakers. 


\section{CHRISTIANITY AND POLITICS}

conscience and concentration on the duties of private life have their part to play at all times. But religious teaching which goes no further is of little help to the democratic citizen as a guide or stimulus in exercising his privileges; it cannot supply fruitful suggestion in regard to matters of State, and to men engaged in active life it seems to be impractical and absurd. We cannot discuss the duties of the community intelligently unless we regard the community as an organic whole which has a life and duties of its own, and not merely as an aggregate of independent atoms.

\section{CHRISTIAN ASSOCIATIONS}

Those who had adopted the new conception of a Christian society, as a purely religious body throughout, were eager to realise it by the only methods that lay within their reach; they seemed to find definite instructions as to their duty in St. Paul's Epistle to the Corinthians: "What com"munion hath light with darkness? And what "concord hath Christ with Belial? ... Wherefore "come out from among them, and be ye separate, "saith the Lord, and touch not the unclean thing." They endeavoured so far as possible to escape from this present evil world; at first they looked to Holland as a district where they might be free 


\section{INDEPENDENTS AND CONSCIENCE}

from the ecclesiastical discipline maintained in England, and a congregation of Independents migrated from London to Amsterdam in 1593. Somewhat later congregations from Scrooby and Gainsborough followed these first migrants. Holland, as a confederation of cities and provinces, had little national unity, and made no attempt to maintain the traditional conception of a Christian polity with a well-ordered religious life. Even in Holland, however, they did not find the atmosphere they desired, and they determined to emigrate to the New World where they might be free, once for all, from the unrest created by political intrigue and the wars of religion. The settlers at Plymouth were followed by a still larger number who planted themselves on Massachusetts Bay in 1629, and during the seventeenth century fresh bodies of settlers continued to arrive who were animated by the same spirit. The inhabitants of the Welsh Tract in Pennsylvania in 1690 gave expression to the feeling which was at work in the planting of the New England colonies, as well as that of Pennsylvania. "We can declare," they say, "with an open face to God and man that we "desire to be by ourselves for no other end or pur" pose but that we might live together as a civil "society to endeavour to decide all controversies "and debates among ourselves in a gospel order 


\section{CHRISTIANITY AND POLITICS}

"and not to entangle ourselves with laws in an "unknown tongue, as also to preserve our lan"guage that we might ever keep correspondence "with our friends in the land of our nativity." 1

Even in Pennsylvania, where the conditions were most favourable, it was not always possible to avoid causes of quarrel. Though the Indians, as a class, were peaceable, the Welsh Settlers had some trouble with "bad Indians," who roamed the forests and made occasional raids on the live stock of the farms. The rights of property were differently interpreted by Penn and by his Welsh tenants ${ }^{2}$ in Pennsylvania; and the views of Roger Williams in regard to civil rights led to his expulsion from Massachusetts; nor was it possible to exclude religious differences altogether, since not all the settlers would agree to the disuse of the Book of Common Prayer. By the end of the seventeenth century it became clear that the attempt to found a new civil society on strictly Christian principles had resulted in failure. A Christian society in the world cannot hedge itself round in such a fashion as to have a complete immunity from the intrusion of mundane and secular affairs. Christians cannot avoid contact with their environment, and live their own life in isolation.

1 Browning, op. cit., 379. 2 Ibid., op. cit., 388. 


\section{INDEPENDENTS AND CONSCIENCE}

The difficulties with which these congregations had to deal did not merely arise from their environment, but were partly due to the difficulty of maintaining a high Christian standard in their internal life. Those who, as members of the Covenant of Grace, had been admitted into Christian fellowship, were inclined to claim that none of their brethren was justified in overruling the conscientious convictions at which they had arrived. Mrs. Hutchinson claimed a right to abstain from the religious ordinances which the community maintained, and to criticise in forcible language the discourses delivered by the ministers. She maintained a double weekly lecture " where after "she had repeated the sermon she would make her "comment upon it, vent her mischievous opinions "as she pleased and wreathe the Scriptures to her "own purpose." 1 It is not necessary to try to unravel the threads of this famous controversy; but it may suffice to point out that while the conscience is supreme within, the expression of conviction in word or deed may be rightly taken into account by an external authority. Even in the most spiritual community those who claim to be within the Covenant of Grace are not thereby excused for disparaging the Covenant

1 Short Story of the Rise of the Antinomians, quoted by Willcock, Life of Sir Henry Vane, 46. 


\section{CHRISTIANITY AND POLITICS}

of Works. "The Kingdom of God is within "you."

These practical experiments were perhaps of less importance than the habits of thought on political matters which they expressed and helped to perpetuate; the conception of a Christian polity as one community considered in two aspects, civil and religious, was abandoned in favour of the view that the two spheres, the civil and the spiritual, were distinct. Roger Williams formulated it thus, "We acknowledge the ordinance of mag"istracy to be properly and adequately fitted by "God to preserve the civil State in civil peace and “order; as He hath also appointed a spiritual gov"ernment and Governors in matters pertaining to "His Worship, and the consciences of men, both "which Government, Governors, Laws, Offences, "Punishments are Essentially distinct, and the "confounding of them brings all the world in Com"bustion." 1 This endeavour to draw a clear line between the two spheres is very tempting, but it is well to notice what it implied. The spiritual sphere was regarded as definitely religious, where all was to be ordered under a conscious sense of duty to God, but it does not seem to have been possible to maintain the same standard in regard to civil life. From an early date the membership

1 Quoted by Willcock, Life of Sir Henry Vane, 149. 


\section{INDEPENDENTS AND CONSCIENCE}

of the churches in Massachusetts was not identical with the residents of the community; and when the unenfranchised at last secured a voice in the civil government, it came to be clear that the principles to which appeal was made in the religious sphere were not identical with the principles to which appeal was made in the civil sphere. The civil sphere was no longer consciously religious; and hence the standards of right and wrong were given, not by spiritual authority but by natural reason or utilitarian considerations. The attempt to establish a perfectly pure Christian community had resulted in driving the regulation of civil affairs and secular life into a sphere where religious considerations were at all events not primary, if indeed they were relevant at all. The attempt to separate the spiritual from all contact with a mundane environment and to keep it immune from contaminating influence, resulted in the disparagement of civil and political society as merely mundane, and led to the abandonment of efforts to control them by means of religious influence. When the conscious effort to realise the Will of God was confined to the spiritual sphere, the first step was taken towards recognising the will of the people - good or bad, wise or foolish - as paramount in the civil sphere. 


\section{CHRISTIANITY AND POLITICS}

IV. UNASSIMILATED ELEMENTS IN ENGLISH SOCIETY

At the Restoration, Parliament took up the endeavour to assert the old conception of a Christian polity more vigorously than ever before. Twenty years' experience had forced many men to feel that the reassertion of the old order in Church and State was the only safeguard against the destruction of the parochial system and the dangers of military despotism. The Presbyterians, who held to monarchical government and national Christianity, were unable to get a hearing for the system they would have preferred. It was remembered against them that the rebellion in Scotland against Charles I had led to the outbreak of civil war, and their ideals of loyalty were not easily comprehensible by the English mind. The Long Parliament of the Restoration endeavoured to safeguard the restored system in Church and State, by turning against the Puritans the weapons which they had forged for attacking the Church of England. The Clarendon Code was the result; and, as a consequence, the various Puritan bodies found themselves in a much worse case than before the Civil War; then they were only thwarted and hampered by ecclesiastics whose position was constitutionally doubtful, but henceforth they 


\section{INDEPENDENTS AND CONSCIENCE}

were harried by the authority of Parliament and under the Statutes of the Realm. The religious elements that could not be assimilated to the restored order in Church and State were necessarily placed in a position of antagonism to the institutions of the society in which they lived.

While the Puritans were an object of suspicion to the civil authorities, on account of their political principles and their affinities with the Dutch, there was not much in the restored monarchy that could claim their respect. The Court was corrupt; the severity which had been imposed on the nation generally by the anxieties of the war and the administration of the Puritan régime was suddenly relaxed. The restored clergy did not always commend themselves by their preaching, or by their lives, to their parishioners; it must have been exceedingly hard to feel that there was any Christian obligation to obey such a government. On the other hand, the loss of the liberty of forming gathered congregations, which they had enjoyed during the Interregnum, was bitterly resented, and the Puritans felt it a religious duty to stand on their civil rights, to work hard for an extension of these rights and to endeavour to obtain the repeal of all the disabilities under 


\section{CHRISTIANITY AND POLITICS}

which they lived. These circumstances combined to give its special character to the Dissenters' sense of the duty of a Christian citizen. They were inclined to explain the duty of obedience to human law away altogether. Mr. Thompson, a dissenting preacher, argued that "Scripture tells "us we must obey the men only in and for the "Lord, which limitation," he said "being ad"mitted, I still assert that I have not broken the "law of God, though I have the law of man." 1 On the other hand, there appeared to be ample reason for Dissenters to appeal to religious motives to induce men to stand upon their civil rights. It is true that the determination to assert personal rights of any kind is not at first sight in accordance with the Christian spirit, and though ample excuse may be made for earnest men in the position in which they found themselves, their circumstances did not fit them to throw much light on the difficult question as to the personal duty of the Christian citizen towards those in civil Authority. The doctrine of the two spheres was in itself an obstacle in the way of making any such attempt. In the Presbyterian Theocracy the effort to bring religion to bear on economic transactions had ceased, and the triumph of Independency and the doctrine of the

1 Caxton, Independency in Bristol, 49. 


\section{INDEPENDENTS AND CONSCIENCE}

two spheres had a similar effect in disassociating religion from politics.

This leaven worked so effectively as to produce a marked change in the character of the English Realm at the time of the Revolution and the accession of William and Mary. It may be said that the traditional conception of a Christian polity, with a well-ordered religious national life, fell into desuetude; although formally retained, the religious factor, as a dominant influence, was eliminated.

The State continued to acknowledge religion, but ceased after the reign of Queen Anne to make active efforts to foster or promote it. This was inevitable, since two incompatible ideals of what a Christian polity should be were simultaneously accepted by the Crown. Presbyterianism became the established form of religious organisation in the Scottish Realm, though episcopacy was retained in England, and this course was confirmed by Parliament in the Act of Union. This politic indifference to the religious aspect of national life was a bitter disappointment to those who had sacrificed much for the Presbyterian Theocracy, and also to those who were most enthusiastic about the principles for which the English Church had suffered terribly under the Puritan régime. 


\section{CHRISTIANITY AND POLITICS}

Indifference to religion on the part of civil authority was noticeable, not only at home but in the plantations. In the colony of Carolina, for which the constitution was drafted by John Locke, the religious enthusiasm which had had such a large part in the planting of other settlements was completely absent. The Elizabethans would never have thought of settling a body of Roman Catholics in the New World. There are no signs of the sense of national mission, which had taken hold of the Elizabethans, nor of the desire to establish an uncorrupt Christian community, which had inspired the settlers in New England. The religious motive was no longer effective, but considerations of finding employment for our population and increasing our trade were mainly at work: the economic rather than the religious aspect of society was becoming a primary consideration.

John Locke not only helped to devise a constitutional scheme for a new colony, but formulated a theory of civil government which has had an extraordinary influence from his time onwards. It has been widely welcomed because it provides a political doctrine from which religion has been practically eliminated. Civil society is spoken of as based on purely utilitarian considerations, and as formed by individuals who enter into a contract 


\section{INDEPENDENTS AND CONSCIENCE}

with one another to sacrifice some of the personal liberty they enjoyed, on account of the greater advantages which accrued to them by living together in society. The Independents had conceived all Churches as gathered by the association of individuals into a solemn Covenant with God, while Locke conceived of the State as formed by a prudential contract of individuals with one another. The Independents had found it hard to combine submission to authority with the conviction of the supremacy of the individual conscience, and Locke and his followers have had the same difficulty in devising a duty of civil obedience, and of showing how the liberty of the individual is to be rendered compatible with the authority of the State.

\section{THE GROUNDS OF CIVIL OBEDIENCE}

There is an obvious incompatibility between the duty of obedience to the Crown as it was put forward and acted upon in the reign of Elizabeth, and the assertion of the supremacy of the conscientious conviction of individuals. In her days the Crown had been solely responsible for the public good, and it was by obedience to the Crown that the subject was best able to contribute his efforts, in co-operation with other subjects, for the common good. Loyalty and obedience to 


\section{CHRISTIANITY AND POLITICS}

the Crown were regarded as almost the sole duty of the subject; but even though we regard the view that was then commonly held as exaggerated, the duiy of obedience remains, and is still incumbent on all the members of a community. Citizenship in a democratic state has a two-fold character; the citizen has a voice in the government of the country and helps to decide what the law shall be, but he is also a subject who must obey the law. The fact that he has the privilege of sharing in the responsibilities of government does not absolve him from the duty of obedience. When the decision of the country is once taken on any point of policy, the citizen, who may think that that decision is mistaken, is no longer justified in setting up his own judgment against that of the community of which he forms a part. When the government of a country has decided upon going to war, the citizen, who is opposed to all wars, is bound to acquiesce, at any rate by silence, so as not to weaken the hands of his countrymen in the struggle on which they have entered. ${ }^{1}$ In democratic, as in other communities, the conflict between personal conviction and

1 This acquiescence need not involve any tampering with conscience. If there were a definite conflict between his conscientious conviction and the demands of the government for his active obedience, as in the conscription of a Quaker, he could save his conscience by firmly refusing to serve, and at the same time show his obedience to the State by submitting to the punishment imposed. 


\section{INDEPENDENTS AND CONSCIENCE}

civil obedience may arise, and it is impossible to deal with it in general terms; at the same time some considerations may be adduced which help to show that, if the difficulty is carefully faced, reconciliation may not be impossible.

It was pointed out in the seventeenth century that the duty of civil obedience did not necessarily involve an active compliance with the commands of a civil authority, and that no one was bound to do, at the bidding of man, that which he consciously believed to be wrong in the sight of God; he could sufficiently show his respect for the civil authority, if, while refusing to do what was commanded, he submitted without complaint to the punishment. William Stubbs, whose writings against the hierarchy had led to his punishment by the loss of a hand, showed his respect for authority by immediately using the maimed stump to lead a cheer for the Queen under whose authority he had suffered. The story of the three Jewish youths, who refused to obey Nebuchadnezzar and submitted cheerfully to the punishment he imposed, was a scriptural instance which was habitually urged in this connection; but under changed circumstances it is hardly possible for anyone to show his respect for authority by the manner in which 


\section{CHRISTIANITY AND POLITICS}

he submits to punishment. His punishment is sure to be taken up by a section of the public, and to be used as a means for agitating against the manner in which authority has been exercised. Passive obedience, as practised in the sixteenth or seventeenth centuries, was a genuine method of expressing respect for civil authority, but passive resistance, as recommended in the twentieth century, has merely been an insidious method for paralyzing civil authority and bringing it into contempt.

Again, in a democratic community, the duty of civil obedience does not involve abject subservience, or abandonment of a claim to resist in selfdefence. The private individual is, by common consent, justified in appealing to force in selfdefence, and in a free government, no man is bound to divest himself of his civil rights. There may be resistance to the King's advisers and administrators on the part of those who hold "that "the King can do no wrong," but that his Ministers have been guilty of encroachment on the rights of the subject. Hampden's refusal to pay ship-money was not so much disobedience as a form of raising a grievance, and bringing it forward to be settled by law. Further, there may be a question as to the title of anyone to exercise rule. There were conscientious men who rejected the 


\section{INDEPENDENTS AND CONSCIENCE}

title of the Austrians to rule in Lombardy, or of the German Empire to authority in Alsace. The protest against usurped and arbitrary power may arise in many democracies owing to the difficulty of determining whether some particular administration is giving effect to the will of the people or not. ${ }^{1}$ This is the ground on which the Ulster Covenanters have taken their stand, while strongly asserting their loyalty to the British Crown and the British flag.

While the duty of obedience is no longer pressed in such an absolute form as was once the case, there is in the present day a great readiness to assert conscientious conviction as paramount, and as something which it is a duty to insist upon at all hazards; but there is at least a presumption that anyone, who thus constitutes himself a supreme judge of what ought to be done in the community, and insists upon giving effect to his conviction, if need be by force, is mistaken. There can be no pretension that it is ever right for the private individual to avenge his private grievances himself, and it is difficult to contend that this is either the best or the only way by which what are felt to be public wrongs can be righted.

Defiance of authority, with an appeal to force

1 A. Lawrence Lowell, Public Opinion and Popular Government, 12. 


\section{CHRISTIANITY AND POLITICS}

in connection with any alleged injustice, is certainly evidence of the reality of a grievance and the earnestness of those who desire to have it removed. Their conduct is commonly excused on the plea that force and defiance of the Government is the only method by which the desired concession can be wrung from the Government. But this plea is not convincing; it is often said that the peasants succeeded in shaking off serfdom by their rebellion in 1381; but the more the case is considered, the more it may be doubted whether their appeal to force did much to improve their condition. The process of commuting personal service for a money compensation had been going on rapidly before the time of the revolt; it is not clear that it was greatly accelerated. In Scotland, where there was no peasants' revolt, the rural population obtained to economic freedom and shook off the vestiges of serfdom much earlier than they did in England, and the economic condition of the labourer in some of the English counties to which the revolt did not spread, has long been as good, or better, than that of the labourers in Kent or Essex; nor is it evident that the material prosperity of the French peasantry was improved by the Revolution. So far as these stock instances go, it is not clear that appeal to force justified itself by its successes, for it must be re- 


\section{INDEPENDENTS AND CONSCIENCE}

membered that this method for securing a remedy is very clumsy and expensive. Those who entered on the Civil War, to defend English constitutional liberties against the encroachments of Charles, may well have been disappointed at the result which was achieved, when the military despotism of Cromwell was thrust upon them; there had not been a very decided gain for constitutional liberty in spite of all the expenditure of blood and treasure. There may be good reason to defy civil authority and resist it, if there is a high probability of success in establishing a better system of government; but it must always be a political crime to try and obtain a particular privilege by means which hamper the exercise of authority or bring it into contempt.

The reckless assertion of individual convictions has been greatly encouraged by the more general acceptance of the view of the State as a mere aggregate of atoms, and the inability to look at the community as an organic whole. ${ }^{1}$ If the community has no real life of its own, but is a mere name for a greater or larger mass of individual human beings, there is difficulty in conceiving of any duty to the community, or of thinking of it apart from private activities. We can trace the play of

1 Cunningham, Christianity and Economic Science, 86. 


\section{CHRISTIANITY AND POLITICS}

individual interests, present and to come, in economic science, and we can lay stress upon the power of humanitarian sentiment and the principles of ethical science. We may be satisfied to be swayed by one or other of these considerations in turn; but we can hardly hope to be self-consistent, or to bring these two sides into relation, unless we have some such conception as that of duty, in which considerations of interest and of sentiment may each find a proper place. Economic science can enlighten us as to certain evils we would do well to avoid, and sentiment may supply a driving force to initiate improvement, but the two sides must be brought together if we are to have a real guide to progress.

Though we may analyse the community into the individuals who compose it, we cannot account for individual rights or aspirations without looking beyond them. Each of us has been placed under obligations by the social system, and the developed material conditions in which we have been born; we have relations of neighbourliness to our fellow-citizens in our own locality and our own country, and we are bound to strive to pass on to others a civilised society that is as good or better than that which has been our heritage. The national life has a character of its own, and is not a mere stream of individual lives, each guided 


\section{INDEPENDENTS AND CONSCIENCE}

by its private tastes and interests. The sense of membership of a community and obligations to the community have been an inspiration for the heroes of the past, who devoted themselves to the cause of their country; and there cannot be a wholesome life in the present, unless men are prepared to admit their obligations to the community as a whole and are ready to discharge them at some sacrifice.

The sense of duty to the community is a very real force in the present day, and it is not easy to account for it on rational grounds, if we acquiesce in the elimination of the religious element from politics. Why, anyone may ask, should I be taxed to provide education for the community? If I have no children, the facilities for instruction are no good for me. Why should I pay for an Army and Navy if I disapprove of war? Why should I develop resources for the benefit of posterity since posterity has never done anything for me? Why should I yield obedience to the magistrate unless I see that it is my interest to do so? To the religious man, whether Theist or Christian, such self-interested questionings seem idle and irrelevant, and the answers are plain.

The religious man believes that God governs the world, that the destiny of the nation is in His hands, and that it is through them that $\mathrm{He}$ 


\section{CHRISTIANITY AND POLITICS}

accomplishes His purpose for Mankind. In His Providence the civil ruler has come to wield earthly power; and by rendering what is Cæsar's to Cæsar we are rendering obedience to the God Who has placed him where he is. St. Paul elaborates the argument and says, "Let every soul be "subject unto the higher powers. For there is no "power but of God: the powers that be are or"dained of God. Whosoever therefore resisteth "the power, resisteth the ordinance of God: and "they that resist shall receive to themselves dam"nation. For rulers are not a terror to good works, "but to the evil. Wilt thou then not be afraid of "the power? Do that which is good, and thou "shalt have praise of the same. For he is the min"ister of God to thee for good. But if thou do that "which is evil, be afraid; for he beareth not the "sword in vain; for he is the minister of God, a "revenger to execute wrath upon him that doeth "evil. Wherefore ye must needs be subject, not "only for wrath but also for conscience sake." Such Christian teaching gives us light as to the real nature of the obligations we owe to the community, while it also furnishes us with an incentive for doing these duties at some personal sacrifice. 


\section{V \\ RELIGION AND PUBLIC SPIRIT}

\section{SELF-DISCIPLINE AND GROWTH}

The Ecclesiastical Courts had been so unpopular as to become a political danger under James I and Charles I, and little attempt was made to revive them after the Restoration. They were not used to enforce the observance of fish days, and such secular ordinances; and in so far as ecclesiastical discipline was re-introduced, it seems to have dealt chiefly with moral offences, such as drunkenness and slander. In this modified form it did indeed give rise to some complaint, but there never seems to have been any general attempt to enforce it systematically, and we hear little of it after the beginning of the eighteenth century when Bishop Wilson tried to re-introduce it in the Isle of Man. ${ }^{1}$ In so far as this religious discipline was revived, we see that it had a somewhat different character from that enforced in the Presbyterian theocracies. There the end in view had been the preservation of the Christian community from

1 J. Wickham Legg, English Church Life, 256. For instances of public penance in Yorkshire in 1731 see Whytehead, "Discipline of the Church," in Yorkshire Archaological Journal, xIx, 80. 


\section{CHRISTIANITY AND POLITICS}

scandal; but the aim of those who desired to restore ecclesiastical discipline in England was to bring about the repentance and restoration of the sinner personally. The Commination Service, and the public discipline of which it is an echo, were intended to be a definite call to repentance on the part of sinners, in the hope that they would use the season of Lent aright, and could thus be restored to communion at Easter.

The tendency of the Calvinistic doctrine of predestination and election had been to throw the need of individual growth in the religious life somewhat into the background; but the religious revival, which arose under the influence of Cosin, Thorndyke, and other Caroline divines, was a conscious reaction against Calvinism. Though external discipline remained in abeyance, there is ample evidence that large numbers of Churchmen were trying to live more strictly, and to discipline themselves to comply with the standard of Christian life embodied in the Prayer Book. Care was taken to provide opportunities for daily prayer by ecclesiastical authorities, ${ }^{1}$ and daily services were very generally available in London churches in $1714,{ }^{2}$ though the numbers rapidly

1 J. Wickham Legg, English Church Life, 79.

2 James Paterson, Pietas Lundinensis; also Strype's Stow (1720), bk.v, p. 19. 


\section{RELIGION AND PUBLIC SPIRIT}

declined after this date; special attention was called by the Bishop of Ely to the desirability of providing opportunities for daily prayer at villages that lay along the great North Road. ${ }^{1}$ There is every reason to believe much greater advantage was taken of these services by parishioners at the beginning of the eighteenth century, than in the twentieth when they have been once more generally revived. More remarkable evidence still is

1 Dr. Stevens, Vicar of Tadlow, has kindly given me a copy of an interesting letter in his possession, from Dr. Turner - one of the Seven Bishops - to Mr. Say of Caxton: -

ELY, Sept. 11, 1686.

Good Brother, - The good character I have received concerning you from our R[oyal] Mistress in Holland, has given me a particular confidence in yr: care to putt the Direction's of my printed letter in practise. Yr parish, if it be not so numerous as I suppos'd yet lyes on the Great Northern Roade: it would be for our churches Honor and for the consolation of well dispos'd Travellers to find Daily Prayers in yr: Church. I press them all over the Diocese where it is practicable, but at Caxton I wd: have them by all means, tho' you begin with a congregation of butt a widdow or two. Have them if you please at six or seven in the morning, if that will be best for passengers. My good friend you have been bredd in a camp of Toyle and Hardship. I know the putting my orders in execution, that is the making so many careless people Christian indeed, will cost you a great deale of Labour: but do not grudge it; you are sure of as great a Reward in Heaven; and in good time you may find you account by it here, for I do not forget what her Highness commanded in favour of you, and now I give it to you under my own hand that I will remember it to your advantage; you shall not stay long at Caxton if I can help it. But in the meantime do your own Business with all your might, and sett into its presently before the Visitation; By which you will more than a little oblige, Sir,

Mr. SAY of Caxton.

$$
\text { Yr: affect. friend \& Brother, }
$$

$P . S$. If you have no little schoole in yr: town I shall wonder, and you ought to procure one. If there bee one, then you need not want a congregation for both morning and evening prayers. 


\section{CHRISTIANITY AND POLITICS}

furnished by the number of voluntary societies which were formed for mutual encouragement in the devout life; a very interesting account of them is given by John Chamberlayne in 1708: "The "Religious Societies are so called, because the "particular end and design of them is to improve "themselves and others in the Knowledge of our "most Holy Religion, and to animate one another "in the serious practice of it. They were begun in "London about the year 1678, by a few serious "young men of the communion of the Church of "England, who, by the Advice and Direction of "their Spiritual Guides agreed to meet together "frequently for religious Conference, and by "Prayer and Psalmodie to edifie one another. “... They industriously apply themselves to "the relieving poor Families and Orphans, set"ting Prisoners at Liberty, solliciting Charities "for the pious Education of poor Children, Visit"ing and Comforting those that are Sick and in "Prison, and Reclaiming the Vicious and Disso"lute; in promoting Christian Conference, Decency "in God's Worship, Family Religion, and the Cate"chizing of young and ignorant People."1 Similar societies were formed in other towns, notably in Truro. ${ }^{2}$

1 Magna Britannice Notitia (1708), p. 276. Compare also Strype's Stow, bk. v, p. 40.

2 J. Wickham Legg, English Church Life, 299. 


\section{RELIGION AND PUBLIC SPIRIT}

The most remarkable development was among the group of men which gathered round Wesley at Oxford and gave rise to the great religious movement which still bears the name of Methodist. The genius of John Wesley used the system, which had been devised for the mutual encouragement of pious men, as an organ of mission work, and for the strengthening of those who were impressed by the power of his preaching. Wesley's own position, as revealed in his Journal, is somewhat anomalous; he had been an enthusiast for the maintenance of Christian institutions as established in the land. He set himself earnestly to live up to them in Oxford, and he was eager in trying to maintain Church discipline among the people in Georgia. He had a strong sense of the importance of Christian rites, and he based his claim to preach on the fact that he was an ordained priest of the Church of England. This was the warrant of his mission; but while he relied so much upon ecclesiastical order, he thought it inadequate, and had little scruple in waiving it aside. His sense of a spiritual mission refused to be restricted by the bounds of the parochial system; "all the world is my parish." He believed intensely in the working of God's Spirit in the individual heart and conscience. He accepted the Christian polity and ecclesiastical 


\section{CHRISTIANITY AND POLITICS}

ordinances as affording a useful atmosphere; but for him, fellowship in a Christian polity was a poor thing, unless there was the growth of personal Christian life. His followers were encouraged to provoke one another to love and good works in class meetings, and to stir up the gift that was in them; but the societies he founded were strictly religious societies, and were concerned in fostering the personal religious life of individuals.

Wesley did not differ from other English churchmen either as to the duty of maintaining religious ordinances within the realm, or the importance of diffusing religious truth among Englishmen settled abroad. There was no divergence from the current view of the duty of the State; but Wesley left it to others to discuss the manner in which these national duties should be done. His whole energy was devoted to fostering the growth of spiritual life in individuals. In so far as he paid attention to secular affairs in political life he was only concerned to notice how they reacted on the personal religion of men and women. From this standpoint he is inclined to deprecate earthly cares and worldly interests as unfavourable to spiritual progress. He feared material prosperity as a danger to Methodism. "Religion," he said,1 "must necessarily produce ${ }^{1}$ Southey's Life, II, 522. 


\section{RELIGION AND PUBLIC SPIRIT}

"both industry and frugality, and these cannot "but produce riches. But as riches increase, so " will pride, anger, and love of the world in all its "branches. How then is it possible that Meth"odism, that is, a religion of the heart, though it "flourishes now like a green bay tree, should con"tinue in this state? For the Methodists in every "place grow diligent and frugal, consequently they " increase in goods. Hence they proportionately " increase in pride, in anger, in the lust of the "flesh, the desire of the eyes and the pride of life." Ample evidence might be adduced to confirm his view; the very success of the monasteries as centres of organised economic life, had been prejudicial to their religious tone and'influence, and the experience of the Society of Friends has been similar. ${ }^{1}$ In his sermon on the use of money Wesley warns against the personal sins that may arise in connection with earthly gain. ${ }^{2}$ But just because his religious teaching is so personal, he has given little suggestion as to the moulding of society itself on Christian lines, or as to the means by which a more Christian polity may be secured. This lay beyond his purview; indeed it is one of the most interesting points of contrast between

1 J. J. Fox, Enquiry into the Causes of the Weakness of the Society of Friends as a Christian Church (1859).

${ }^{2}$ The Use of Money. Wesleyan Methodist Union for Social Service, Social Tracts, New Series, No. 1. 


\section{CHRISTIANITY AND POLITICS}

the work of John Wesley and the work of General Booth, that the latter realised how unfavorable physical surroundings may be, and that they often may prove an almost insuperable hinderance to the growth of personal religious life. The importance of material conditions in regard to the outcast and the miserable has been the most important development of Salvation Army work; but the aim in view has been that of Wesley, in reclaiming individuals, rather than that of remodelling society itself.

\section{THE DUTIES OF THE COMMUNITY}

There is very little trace among the Calvinist communities of a conscious mission to the world. The Scottish nation, and the gathered churches in New England, were keenly conscious of their position as testifying to the truth - like a city set on a hill; but they inherited the Old Testament attitude of mind; and they had little sense of a duty towards heathen peoples which was incumbent upon a Christian nation. But in England the sense of the destiny and of the duties of the nation had never died out; it had been awakened by the danger of absorption by Spain in Tudor times, and it was quickened by the threats of French encroachment. Seventeenth and eighteenth century sermons afford ample evidence of the manner in 


\section{RELIGION AND PUBLIC SPIRIT}

which this and the other Christian duties of the community were kept before the public mind, and show that this central conviction was the foundation of teaching in regard to the duties of Christian men in their social relations. The most obvious duties, in the period before the Industrial Revolution, were not the same as those which claim attention at the present day; but the dusty volumes and forgotten pamphlets of the eighteenth century give ample proof that preachers inculcated high ideals of national life. During the seventeenth century and the early part of the eighteenth the pulpit exercised a remarkable influence. Pulpit eloquence was cultivated as a rhetorical art, both in France and England; and well-selected libraries of literature contained a large number of volumes of sermons. Before newspapers came into general use, they were the most effective channel for influencing public opinions; there were many benefactions for providing special sermons, and official sermons were regularly preached before public bodies. We have therefore a large body of evidence so little known even to students, ${ }^{1}$ that it seems desirable to quote considerable passages at length, in order to give an idea of current teaching on political and social duty.

1 Copies of most of the sermons quoted are accessible in the British Museum Library. 


\section{CHRISTIANITY AND POLITICS}

The sense of a mission to the world, which had been so strongly felt by the Elizabethan pioneers of empire, was kept alive and reinforced; and this comes out especially in connection with the planting of Georgia. In preaching before the trustees, Glocester Ridley insisted that the economic objects which he enumerated should be subordinated to religious aims. "Prudential and human "motives are but the intermediate wheels and "springs of Providence, which the all-wise Con"ductor employs to produce a much grander "effect, the general and eternal welfare of man"kind.... The reasons before mentioned are "very justifiable and commendable motives of "themselves; but when ranked, where Provi"dence esteems them in subordination to better, "and only as a means subservient to a nobler " end, the design of planting Georgia is a glorious "effort of the human mind, reflects the highest "honour on those engaged in it, deserves the "prayers and concurrence of all good men, and "may depend upon the assistance of heaven to "accomplish His own decrees." The same doctrine was reinforced by the Reverend George Harvest in 1749. “The relation in which we stand "to the Western Isles, by the appointment of "Providence, has afforded us an opportunity of "propagating the Gospel among their inhabit- 


\section{RELIGION AND PUBLIC SPIRIT}

"ants. This relation obliges us, as a Christian "nation in Society, to endeavour to promote both "their temporal and eternal interests. And even "supposing, not admitting, supposing I say the "Utility of this Colony of Georgia to be yet "a matter of some doubt and uncertainty, I "will however appeal to the Christian politician "whether the glorious prospect of promoting Re"ligion - which is above all else valuable - the "salvation of souls,... the extending of the "Kingdom of God upon earth, - whether these "be not things of infinitely greater moment than "any Temporal Emoluments or Advantages."

Bishop Terrick of Peterborough, when preaching before the Society for the Propagation of the Gospel, urged that our successes in the Seven Years' War, "great in themselves and glorious "to the British arms, have extended our Em"pire and opened a large field, which in every "view, whether of Religion or Civil Policy, "demands our culture and improvement. This "is indeed an object too great and extensive "for the abilities of this Society: it is a Na"tional concern, and will, I doubt not, be con"sidered with the attention it deserves. It would "indeed add a lustre to the glories of a successful "war, could we trace the progress of true Chris"tianity, wherever our arms have conquered, 


\section{CHRISTIANITY AND POLITICS}

"and by introducing the Arts of Civil life and "the milder genius of a pure Religion, could "boast of the triumphs of Truth and Knowledge "over Popish error and Heathen ignorance. This "would be an event, which would shine in the "Annals of our History, and do honour to our "National character. And sure it may be con"sidered as a circumstance, which, as it gives "the most favourable impressions of the Spirit "of our Religion, we hope may have some influ"ence in preparing the way for its more general " reception; that wherever the natural courage of "our troops led them on to Victory, the mild and "generous temper of the Gospel disposed them to "triumph with humanity." At a later date the duty of living up to new national responsibilities was borne in mind; during the Napoleonic wars an earnest warning was given by Dr. Carey, in a sermon preached before the House of Commons as to the danger of looking at merely material interests in our relations with the world. $\mathrm{He}$ pointed out that the lust of commerce is as great an enemy to the peace of the world as the lust of Empire, and that the spirit of commerce may easily degenerate into a spirit of avarice and greediness and even of oppression. The effort to maintain high ideals of national life has been steadily pursued by pulpit orators, and found 


\section{RELIGION AND PUBLIC SPIRIT}

\section{admirable expression in Dr. Whewell's sermon before the Corporation of Trinity House in $1835 .^{1}$}

1 This carries the chain of testimony farther. "And though the "ways of Providence must ever be to us dim and mysterious, and "though a reflection which thus points at them may appear to be "vague and unsubstantial, we shall yet, I think, find in it something "which may breathe a warmer air of love, and a nobler glow of hope, "over the machinery of our national prosperity. For, can we doubt "that this nation has been invested with wealth and power, with arts "and knowledge, with the sway of distant lands and the mastery "of the restless waters, for some great and important purpose in the "government of theworld, by Him who guides the course of nations?

"Can we suppose otherwise, than that it is our office to carry civili"zation and humanity, peace and good government, and, above all, "the knowledge of the true God, to the uttermost ends of the earth ? "When we see how the political power of ancient Rome, the extent " and unity of the great empire of antiquity, ministered to the diffu"sion first, and afterwards to the ascendancy, of the religion of "Christ; can we doubt that God uses the institutions of men for the "furtherance of His own secret counsels? Can we doubt that the "command which man, in modern times, has acquired over the ele"ments; the facility with which he visits the remotest regions; the "rapidity with which the discoveries and inventions and thoughts "of one country are borne to the ears of all; the power that cilivized "nations now possess in comparison of those that are barbarous; the "ascendancy which opinion has acquired over brute force; the "supremacy of mind over matter - can we doubt, I say, that all "these circumstances are intended to do their work in carrying on "mankind to a better knowledge of their duties and their hopes; in "advancing them a further step in that school of moral and religious "education in which God is ever instructing them? And, thus view"ing the history of the world, the offices of nations, and the uses of "their powers, we cannot doubt that all our gifts also, the qualities "and possessions which belong peculiarly to this country, are given " us for improving the world, as well as advantaging ourselves; "given as talents, which we are to reverence as the instruments of "high purposes, as well as to use as means to selfish ends. Our place "among the isles of the ocean, our fair havens and lofty beacon-sites, "our commerce and our fleets, our stores and treasures, are thus held "by us as subjects and servants of the Governor of the Universe. "Nor is this all: our better and finer possessions, our advantages of "character and mind, are no less held and exercised under His con"trol and guidance; - the endowments of the soul, courage and 


\section{CHRISTIANITY AND POLITICS}

\section{There was very little official response to these appeals, on the part either of officials or of those}

"invention, energy and endurance; the indomitable will, which no re"sistance of the elemental world can tame; the heart which can brace "the sinews under the fierce smiting of the tropical sun; the eye "which can look steadfastly, though the ice close round like a tomb, "and life seem departing with departing light and warmth; the tem"per on which hope deferred acts only as a fresh stimulus to action; "the sagacity in governing distant lands, which is sharpened, not "baffled, by variety of circumstances. Nor can we less believe, that "the benefits which, as a nation, we have enjoyed, are gifts which "require to be administered for the purposes of the great Giver. Our "long course of health and wealth, of prosperity and happiness; the "foresight of our ancestors, establishing for the guardianship and "promotion of valuable objects peculiar institutions, fitted to avert "the evil, to look onward to the good; the steady course of our his"tory, in which, however changes and struggles may have taken "place, such institutions have always ridden buoyant on the tossing "waves; - all these blessings and benefits, which we perhaps some"times consider as mere matters of pride or advantage to ourselves, "are, in truth, in the scheme of God's providence, something of a "higher bearing, of a larger scope. They are, we may venture to "believe, the instruments of a good, which however it may begin "with us, is to extend to the uttermost parts of the earth, and to the "remotest ages; they are among the means by which light and life, a "clearer light and a purer life, are, as we trust, to be diffused to the "isles of the Gentiles; by which the reign of savage usages, of blind"ness and grossness, shall gradually yield to law and reason, to "moral feelings and religious influences. We cannot and need not "trace the thousand workings by which we improve while we civilize "man; by which the teaching of mere human knowledge and refine"ment, and even commerce and travel, may be expected to prepare "the way and supply the means of religious teaching, in future times "as they have done in times past. But we cannot so far disbelieve "the progress of the better cause, as not to hold, that the activity "and enterprise, the maritime wealth and power, of the most active, "and most enterprising nation, and the most powerful on the ocean "of any which God ever placed on the earth, will be mighty to pro"duce that good which such means are fitted to produce; and that "thus they are part of that great machinery which is to go on work"ing till the knowledge of God shall cover the earth as the waters "cover the sea.

"But, considered in this point of view, such institutions [as Trin- 


\section{RELIGION AND PUBLIC SPIRIT}

\section{who had concessions from the Crown, like the various trading companies and the trustees for}

“ity House] seem to start up before us in new dignity and grandeur.

"If, indeed, the naval greatness of England holds such a place in the "designs of Providence, then all the implements of that greatness, "all the functions of those who watch over and minister to it, ac"quire at once an aspect of serious and elevated importance. If her "ships and fleets, while they pass to and fro, are thus the messengers "of civilization and Christianity, as well as the bearers of wealth and "power, we may well be careful of their management, and tender of "their safety. When we light the frail skiff round the stormy prom"ontory, or mark for it a safe track along the low and treacherous "shore, we know that we have earthly interests, and human life, the "dearest of earthly interests, depending on our care; but that is not "all; we have also in our hands a portion of that great interest of

"advancing peace, and knowledge, and truth, of which the good ends "not in our day, nor on our earth. When we illuminate and direct "the way of commerce and curiosity, of pleasure and gain, over the "great deep, we also send law and order on their course, we light the "gospel on its path, we make the way easy for some benefactor of "mankind to go forth on his errand in hope, or to return in safety to "his native land.

“' 'Be not forgetful to entertain strangers,' says the Apostle, 'for “'thereby some have received angels unawares.' Be not careless or "slothful in aught that concerns the safety or activity of the naviga"tion of this country; for many a messenger of God for good, con"scious or unconscious of his character, is, we trust, confided to its "charge. How can we doubt that the office of our shipping in pro"moting the progress of man's improvement is most important, the "commission of those who are the guardians of its safety most "momentous, when we consider what it has already done? It has "girdled the earth with the arts, the laws, the knowledge, the faith "of these lands, where such blessings are in their most mature "growth and fairest bloom; it has more than once been a bulwark “against a tyrannous and iron despotism, seeking to trample down "the barriers of nations in its barbarising and degrading career; it "has called forth in the men of the land a practical strength and "clearness of the head, an energy and devotedness of the heart, "which we all admire, and feel that we ourselves are bettered by our "admiration, for virtue is stronger by the sight of virtue. The "empire of the ocean is a sacred trust. Well, then, may we rejoice "to see religious offices breathe their solemn and majestic air over "the institutions to which such a trust gives birth. Well may we 


\section{CHRISTIANITY AND POLITICS}

plantations. After the Revolution and especially after the long Whig Supremacy, government practically ceased to take an active part in fulfilling the national mission and commending Christianity to the world. Bishop Berkeley had a bitter disappointment in finding that the political leaders on whom he relied had no serious intention of supporting his project for a Missionary College on the Bermudas ${ }^{1}$ and that they had no sympathy for schemes for fostering national religion among the colonists.

So far as the material prosperity of the country was concerned it seemed to be sufficient for government to guide and direct those who were pushing their own business. There was no general recognition of the danger accruing from eagerness to make a fortune, and there were many who recognised the benefit which accrues to the community from the enterprise of self-interested individuals. It was generally felt in the eighteenth century that so far as the landed interests were concerned their rents were secured, and that they

"recognize, in such a combination, a call to us to administer all that "concerns so mighty a train of operation in a reverent spirit, as "becomes those who are engaged, not only in the diffusion and mul"tiplication of temporal blessings, but also, as we hope, of others of "which the benefit ends not with temporal things." - (From the copy in the Library of Trinity College, Cambridge.)

1 Fraser, Life of Berkeley. 


\section{RELIGION AND PUBLIC SPIRIT}

might be rightly called upon to do a duty to the community, but with the moneyed interests it was different. They ran great risks in developing commerce, in planting colonies and in starting industries, and it was possible to contend that in undertaking such risks for the service of the community they were doing all that could be required of them, and that they had no further duty. Parliament was frequently engaged in inducing men to enter on methods of employing their capital, which would be of advantage to the State, by offering bounties and preferences; and those who earned such public rewards might well feel exempt from any duty to contribute out of their gains to the good of the community. The State had played upon their self-interest, and selfinterest was a guide to their public duty. This principle, which had been already accepted by Calvinist moralists, and which lies at the root of the laissez-faire system of economics, was not universally accepted, however, and it was severely criticised by the Reverend John Geree in an Assize Sermon at Winchester in $\mathbf{1 7 0 6 .}$

"And then it mightily imports us to root out of " our Minds this Principle of Self-Interest, this in"ordinate Desire of promoting our own Advan“'tage, tho' by methods apparently unjust; so the "first thing in order to it, is to examine whence a 


\section{CHRISTIANITY AND POLITICS}

"Humour, now so generally prevalent and reign"ing in the World, does proceed, and in what it is "founded: and that is, either in Luxury and Ex"travagance, for the feeding and supplying of "which Men are forced to have recourse to such "unwarrantable Practices; or else in Idleness, "which puts them upon the shorter and less labo"rious methods of Fraud and Injustice, for the "providing those Conveniences which Industry "might have furnished them with; or lastly in "mistaken notions of what is necessary to their "Happiness, which enlarges the catalogue of their "Wants, and renders them unsatisfied with an “ordinary Fortune, tho' more than Nature re"quires, and what Frugality perhaps would look "upon as a Competency. Were we once arrived at "this Point, that we could retrench our Expences, "and confine them to what comports best with "that condition wherein Providence has placed " us; or that we could shake of[f] that sloth "which ties up our Hands from working out our "Fortune; or could rectify our notions of what is "really and truly necessary to our Happiness in "the World, and square them by the Rules of "right Reason; our Desires would then be easily "reduced within the compass of what is just and "honest. We should not then be tempted to con"clude all our own that we could get; but all our 


\section{RELIGION AND PUBLIC SPIRIT}

"own when we had satisfied the several Ties and "Obligations that lay upon us, whether of Fidel"ity to the Publick or of common Justice to all "men; of Gratitude to Benefactors, of Charity to "the Poor, of Kindness to Relations and the like. "And I instance the rather on Gratitude, Charity "and Natural Affection, because these by Men "too greedy of their Interest, are so commonly "over-lookt. In fine it might be presumed that "then we should acquit ourselves in all the Parts "of Duty to our Neighbour, keeping Truth in our "Promises and Contracts, so as not to disappoint " him or fail in our Engagement to him, tho' the "Performance of it should prove to our own "Hindrance." 1 This was a forcible exposure of the mistake in thinking that, so long as a man attends to his private duties and is guided in business affairs by his own interest, he does all that can be rightly required of him; there is need as well of consciousness that he is part of a community. Each individual ought to be willing to take the trouble of doing his share of the duties which are incumbent upon the community, and this is the very meaning of public spirit. The

1 The theme was a favourite with those who were called on to preach anniversary Sermons to the gentlemen who had been educated at St. Paul's. Archdeacon Tenison, afterwards Bishop of Ossory, recommended a public spirit, because it "produces in every one " of us an extraordinary diligence in the discharge of the duties that " belong to our several stations." 1711. 


\section{CHRISTIANITY AND POLITICS}

eighteenth century was a time of official apathy, and neglect on the part of the government, to live up to a high ideal of the duty of the community, but it was also a time when the foundations of a better order were being well and truly laid. Religious influence acting on individual minds was creating a sense of public spirit which found expression in humanitarian measures at home, and a greater sense of national responsibility for native races abroad. Though national duties and responsibilities were little appreciated by civil authorities, they were more and more taken up by private citizens and by associations of private persons.

Commerce and colonisation were the two occasions of contact which might be utilised by individuals or associations of individuals to supplement official action, and to carry out the mission of a Christian nation. Of all the regulated companies, the Levant Company was that which came into most direct contact with the Mohammedan world, and where the importance of maintaining Christian testimony was most strongly felt; there were eminent men who had successfully held the position of chaplain at the factory in Smyrna. One of them, Dr. Chishull, ${ }^{1}$ in appealing to the members of the Company

1 Guildhall Library. 


\section{RELIGION AND PUBLIC SPIRIT}

in 1698 as to the duty of conducting commerce to the glory of God, puts forward a striking conception of the duty of the Christian merchant: "As "the example of each single person is always to be "measured by the character he bears, so in some "sense it is true that none bears a greater charac"ter than those whom Providence has ordained to "any foreign employment. For the charge which "they carry with them is in truth an inestimable "charge; no less than the credit of their religion "and their native Country. They ought to ap"prove themselves abroad, not only as persons of "sober and honest conversation; but, what is "much more, as becomes true Englishmen and "sincere Christians."

In the sermons preached before the Society for the Propagation of the Gospel there was frequent appeal to the London merchants, who made a profit through trade with non-Christian peoples, to discharge an obligation which was specially incumbent upon them by deputy. This help, says Bishop Trimnell of Norwich in 1710, "is more "particularly to be expected from such persons as "of any wealth and trade in these countries, be"cause they have by the direction of Providence a "more immediate relation to them." There was a very strong feeling in England that the West Indian planters, while making large fortunes, were 


\section{CHRISTIANITY AND POLITICS}

very neglectful of any sense of Christian duty towards those whom they employed. "Too many "complaints," says Dr. White Kennett, subsequently Bishop of Peterborough, preaching before the Society for the Propagation of the Gospel, in which he was keenly interested, "have been made, "that some of our Planters have formerly ob"structed the Conversion of their Slaves, from a "strange Suspicion that they would be then of less "value to them. And that some of our Traders "among the remoter Indians, have artfully in"cited them to Wars and Battles, that after a Vic"tory on either side, they might purchase Slaves "in greater numbers and at easier Rates. I wish "these Men could take the Sin and Scandals upon "their own Heads, and not cast a Reproach upon "our Religion and our Nation. An infinite Re"proach it is for any Christian People to sacrifice "their Religion in the sight of the Heathen, for a "little worldly Gain."

The most notorious case of this neglect arose in connection with the conduct of those who interfered to prevent their slaves from receiving baptism owing to their scruples about the legality of retaining fellow Christians in slavery. Edmund Gibson, Bishop of London, took an active part in exposing the shallowness of this excuse. 


\section{RELIGION AND PUBLIC SPIRIT}

Public spirit was also called upon to perform the duty of the community in seeing to the welfare of those persons who were least able to care for themselves. The sermons before magistrates gave frequent opportunity for dwelling on this as a matter of public importance to the community. Dean Mills, of Exeter, preaching on behalf of the Devon Hospital in 1748, insists that public interest is closely connected with, and in some measure dependent on, the lives and health of the industrious poor. "These "Men are the Sinews of our Government and "the Sources of our Wealth, and as the Riches "arising from them consist in their Industry, their "Health is at least of equal importance to the "Public as their Life; for they no longer live to "Society than they can serve it by their Labour; "whenever Sickness ties up their industrious "Hands they are worse than dead to the commu"nity, for the Balance is then turned on the con"trary side, and instead of being an addition to "our wealth they become a heavy burden to the "public."

Matters which were of such importance in the interests of the community were primarily to be considered as the duty of magistrates, but they were incumbent, in a greater or less degree, on all the members of the community. In an Assize 


\section{CHRISTIANITY AND POLITICS}

Sermon at Maidstone in 1750, the Reverend Peter Pinnell pointed out how much might be done by the magistrates for the improvement of society. "Without their vigilance the best of laws are like "medicine well prepared while distempers rage "for want of application. The jurisdiction of the "gentlemen is so extensive that the very seeds of "crimes, whether they appear in idleness, irregu"larity or any kind of offensive behaviour, may "be choked by a proper exercise of their authority, "and flagrant vices happily prevented by a sea"sonable adversion upon the first buddings of im"piety, and consequently multitudes who might "otherwise be immersed in all filthiness of flesh "and spirit may become diligent in their respec"tive callings." He also argues that such duties are incumbent on all men of wealth and social position, and thus leads from the subject of official, to personal responsibility. "It has been fre"quently observed by writers on the subject of "Morality that every good Man is a Magistrate, " - a Magistrate constituted by Nature though "not appointed by the governing Power. . . . It "is incumbent upon every Member of Society to "have Regard to the Ends of Public Justice, which "are the Restraint of evil Communications and "the support of good Manners, yet still it par"ticularly affects those whose Fortunes afford the 


\section{RELIGION AND PUBLIC SPIRIT}

"fairest Prospect of Success; for in all Matters "that respect our Duty, the Measure of our Obli"gations is to be estimated by our Ability; Since "then Wealth and Honour are the circumstances "that generally give us a superiority over other "men whereby we may easily prepare them to "regard our Counsel and to transcribe our Copy, "since having secular ties upon them, we may, "by these very Cords which bind their temporal "Concerns, draw them to a consideration of their "spiritual interest."

Dr. Mapletoft, writing on the Principles and Duties of the Christian Religion, ${ }^{1}$ insists that Christian duty to our neighbour includes care for dependents; he inveighs against a negative religion, and urges that while it should begin at our families, it should extend to all we have any concern with or reap advantage from. "Such are all tenants "to their respective Landlords; all poor labour"ers and handicraftsmen to those that respec"tively employ them; and all dependents and all "inferiors to those who are their superiors, or who "can make any such pretence to take a more par"ticular care of them, than of others who are in a "more distant relation. Thus all noble, great and "wise men, and all men in general, whose lands "and revenues are improved for them by the toil 


\section{CHRISTIANITY AND POLITICS}

"and sweat of the poorer sort, and all great trad" ers and dealers, who live easily and grow rich by "the hard labour and pains which others take for "them, will find themselves obliged by the laws "of Christian equity and charity ... to make "provision first for the souls, and then too, for a "competent subsistence for them and their fami"lies, and suitable relief of the necessities of all "those by whose sore travail, and usually too "great hardships, they live in so much plenty and "esteem."

Eighteenth century preachers cannot be charged with any apathy in regard to the duties to the community or the value of public spirit; but the first efforts to improve the tone of society itself as well as by moulding public opinion, were very disappointing. At the close of the seventeenth century, when so much was done by Dr. Thomas Bray and his associates for fostering the Christian religion, through the Society for the Propagation of the Gospel and the Society for Promoting Christian Knowledge, attempts were made to carry on something which might be called home mission work by means of the Society for the Reformation of Manners. It started with great promise, but its career of usefulness was somewhat short-lived. The reformation of evildoers 


\section{RELIGION AND PUBLIC SPIRIT}

was the object it professed, but before long its main activities were devoted to the stamping out of vice by informing against prominent offenders, and bringing them before the civil magistrates for punishment. The remedial influence of the members was seriously affected, and they shared the discredit which attaches to common informers. ${ }^{1}$ The story is a further warning, if any were needed, against the illusoriness of attempts to secure real moral progress by external compulsion, whether exercised by Church or State. A much more lasting and abiding influence for good in society was due to those clergy who personally undertook the office of Justices, and helped to raise the standard of the manner in which magisterial duties should be discharged. ${ }^{2}$

There was more success in the efforts to remedy physical evils, and in particular, to make provision for the poor. The eighteenth century was marked by great development of hospitals, where the poor could receive medical and surgical treatment. Provision of this sort had been made in mediæval Christendom both by episcopal authorities and in monasteries. There had also been hospitals founded by private benefit, in many towns, but these mediæval institutions were for the most

1 J. Wickham Legg, op. cit., 302.

2 Webb, English Local Government, Parish and County, 350. 


\section{CHRISTIANITY AND POLITICS}

part turned to other purposes at the Reformation, and no new provision seems to have been made. At the close of the seventeenth century in London, St. Bartholomew's and St. Thomas's were the only hospitals in London, and in the country generally there were no hospitals at all. ${ }^{1}$ But a change was marked by the foundation of Guy's Hospital in 1725; and the reign of George II may be regarded as a great era of the foundation of hospitals in county towns. There were many pulpit appeals on behalf of these institutions. It was felt that this public duty could be best discharged, not by official administrators, but through voluntary help; an opinion which is still generally maintained. "The claims of the sick "poor," said Dr. Parkinson, in preaching for Addenbrooke's Hospital in 1787, "received addi"tional force from their relation to the rich and to "the State. Were some general malady to invade " the health of the peasant, manufacturer and me"chanic, honour and wealth and learning would "become insignificant, as the necessary wants and "conveniences of life would be ill-supplied, and "the State would sink into poverty and weak"ness. ... The health of a poor man, often in"jured in the service of the public, ought to have

1 In twenty-three counties of England there were no hospitals in 1710 . 


\section{RELIGION AND PUBLIC SPIRIT}

"been protected with more vigilance, because " more valuable than property. It is the whole of "a poor man's possessions, and much dearer than "riches to others; since by losing it he is not only "deprived of subsistence, which is equivalent to "the greatest treasures, but sustains perhaps "great bodily pain, for which nothing can be an "equivalent. ... Presuming that the permanent " establishment of hospitals for the sick is the "best remedy, it might be concluded that govern"ment should have made such provision. But the "conduct of the government in only taking the "infirmaries under its protection, which are for "those disabled in the service of the State, may "be justified on these grounds, - such asylums "would have to be supported by additional taxes "on the rich, and being obviously more expensive "would have required greater exactions than "their voluntary contributions. All services in "them would be performed for wages, and there is "something unnatural and shocking to a man of "feeling to show compassion only for gain, or from "compulsion. But what will have most weight "with humane persons is that they would have to "comply with compulsory statutes, instead of "being able to gratify their feeling for the unhap"piness of a brother by relieving his distress." Bishop Butler, in preaching on this topic, pointed 


\section{CHRISTIANITY AND POLITICS}

out the obligations of the middle class as well as of wealthy traders to show this public spirit, "The improvement of trade and commerce has "made another change . . . and I think a very "happy one, in the state of the world, as it has "enlarged the middle rank of people; many of "which are in good measure free from the vices "of the highest and the lowest part of mankind. "Now these persons must remember that whether "in common language they do, or do not, pass "under the denomination of rich, yet they really "are so, with regard to the indigent and necessi"tous; and that considering the great numbers "which make up this middle rank among us, and "how much they mix with the poor, they are able "to contribute very largely to their relief, and "have in all respects a very great influence over "them. It is not only true that the rich have the "power of doing a great deal of good and must be "held highly blamable for neglecting to do it; but "it is moreover true that this power is given them "by way of Trust, in order to their keeping down "that Vice and Misery, with which the lower "people would otherwise be quite over-run."

Still greater evidence of the new care for the physical conditions of individual life was shown in $\mathbf{1 7 7 4}$ by the foundation of the Royal Humane Society. A small society had been founded in 


\section{RELIGION AND PUBLIC SPIRIT}

Amsterdam in 1767, and William Hawes, a public-spirited physician, who practised in the Strand, was strongly convinced of the possibility of resuscitating some of those who were apparently drowned; he gave from his own pocket rewards to all who brought the bodies of the apparently drowned to his surgery, and he was so successful that a circle of friends desired to relieve him of the financial responsibilities and to carry on the work on a larger scale. This was the first of the great philanthropic movements where care for individuals was put in the forefront, and the benefit and interest of society was relatively out of sight. Just as John Wesley's preaching, and the class system which grew out of it, was primarily devised for the fostering of personal religious life, so some of the philanthropic movements of the eighteenth century took the form of pitying personal suffering and seeking to relieve it, where the interests of the State were only remotely concerned.

The other philanthropic movements of the later part of the eighteenth century had the same character. Attention was directed by Howard to the miserable conditions of the prisons, and much was done under his initiative to improve the state of affairs, and to do away with jail fever. In much the same way we may note sympathy with 


\section{CHRISTIANITY AND POLITICS}

child suffering, and a desire to remedy it. The cruelties which were inflicted on the boys who assisted in chimney sweeping, when first pointed out, came as a shock to the public conscience, and endeavours were made by statute to prevent the continuance of the evil. Sir Robert Peel felt the defectiveness of the arrangements for children, who were apprenticed in his spinning mills, and brought in a measure which might introduce better conditions, both for health and for education. The close of the eighteenth century saw the formation of a Society for Bettering the Conditions of the Poor, and the members seem to have felt their way to the conclusion that the truest benefit they could confer on the rising generation was to provide more general facilities to fit them for their place in society. The British School Society and the National Society are monuments of this new care for education as a means of making the most of each individual life.

This feeling of pity for individuals was not confined to those who were of our own blood, and our own country. It entered very largely into questions which arose in connection with the foreign possessions and foreign trade of the country. Burke's eloquence awakened a new sense of our responsibilities for the subject populations of 


\section{RELIGION AND PUBLIC SPIRIT}

India. The imagination was struck by the pictures which were presented of the cruelty of slave raids and the misery of the Atlantic passage, and the Movement for the Abolition of the Slave Trade was carried through with success, while there was also a new development of missionary enterprise. The aim of the founders of the Society for the Propagation of the Gospel had been to extend the Christian polity in the world, but the founders of the Church Missionary Society and Baptist Missionary Society were convinced that the dark places of the earth were the habitations of cruelty, and were inspired by a sense of pity for those who were personal sufferers. From the beginning of the century to the close there are signs of public spirit, and active beneficence, which was initiated by individuals, or bodies of individuals, who thus made up for the neglects of the State.

\section{THE PROSPERITY OF THE COMMUNITY}

When we consider the keen efforts which were made throughout the eighteenth century to stir up public spirit, and to rouse the sense of pity, and when we note the response which was made to these appeals, it seems extraordinary that so many twentieth-century writers should speak of the eighteenth century as if apathy and neglect 


\section{CHRISTIANITY AND POLITICS}

were its chief characteristics. There is, however, some little excuse for this exaggeration when we consider material progress within the realm. In the view which was commonly taken of the pioneers in the agricultural and industrial revolutions, the adoption of improved husbandry instead of old methods of tillage was a benefit to the State; it added to the food supply and gave an opportunity for the growth of national wealth and national power. Looked at from the national standpoint it was a gain; and the incidental suffering which occurred in the march of progress did not receive the attention it deserved. Arthur Young was full of admiration of the improving landlords, who incurred great expenses to do away with the obstacles to better husbandry which were imposed by the system of common cultivation in common fields. It was only towards the close of his life that he came to realise that the revolution, which he had described with such enthusiasm, had tended to depress the rural labourer and leave him in a condition of hopeless poverty. He commended the change from the point of view of the material resources of the community, while the other side was not obvious.

In a similar way it was felt that the men who had enterprise enough to open up new coalfields in Scotland by sinking their capital 


\section{RELIGION AND PUBLIC SPIRIT}

in mines, and providing the necessary equipment for carrying on the industry, were contributing to the material prosperity of the nation. They were regarded as public benefactors, and regarded themselves in that light; many of them felt no responsibility for the moral and religious welfare of the new population that had sprung up in connection with their enterprise. The parochial system, at any rate in Scotland, was unable to cope with the difficulties which arose in the congested districts, and there seems to have been an appalling neglect of the most elementary requirements of civilised life among the mining population. The assistant commissioner, who reported on the condition of Scottish mines, felt that he was making a new demand on the obligations of the mining companies and the land-owners, and feared that it might be necessary for the State to bring compulsion to bear upon them in regard to the condition of their dependents. "Let it not be imagined for a moment," he said, "that gentlemen who have shown such "enterprise and skill as is displayed at [Gart"sherry] have not deserved well of their country, " - all I strongly insist upon is that their own "interest, as well as those of the country, require "that a quota of this wealth shall be deemed due, "from the very first creation of a public work, to 


\section{CHRISTIANITY AND POLITICS}

"be set apart for the religious and secular educa"tion of the population employed." ${ }^{1}$ He regarded voluntary effort as inadequate and held that "Parliament must . . . provide for every member "of the State his birthright by the laws of Eng"land, instruction in the duties, the warnings, "the promises and the consolations of Chris"tianity; such instruction can be adequately and "regularly supplied only by making the cost of it "a necessary incident to all increase of property "which involves an increase of population." 2 The capitalists were so clear that they were fulfilling their duty in promoting the wealth of the community that they felt no responsibility about their dependents. At the beginning of the eighteenth century there had been a contrast between the tradition of the landed interest in recognising public responsibilities, and the attitude of the moneyed interest in failing to acknowledge them. But as the century advanced and capital was invested in the improvement of agriculture and the development of mines, the capitalists' point of view was retained; they were satisfied with themselves for promoting the material progress of society as a whole, at the very time when a sense of pity for individuals and duty towards

1 Parliamentary Papers, Reports, 1842, xvi, 355.

2 Ibid., 349. 


\section{RELIGION AND PUBLIC SPIRIT}

individuals was being more generally aroused. It is not true that the country was apathetic, but it is true that those who were devoting their wealth to promoting the material progress of the country were blinded by self-satisfaction, and failed to recognise the obligations they were incurring in regard to human lives.

When we once realise that the indifference to the sufferings of the working classes, which characterised the early part of the nineteenth century, was not due to moral obliquity but to intellectual error, it becomes a warning for all time. It helps us to see how mischievous an intellectual error may become, and what danger may arise from mere confusion of thought. The men of that time identified the prosperity of the community with the prosperity of the individuals who composed it. English industry and commerce had grown extraordinarily in spite of the war, and it was not unnatural to assume that individuals must necessarily be prospering too. This assumption seemed to be a mere truism, so that the men of the time felt no call to look behind it, and rendered themselves incapable of attending to or interpreting the misery that was going on under their eyes. They regarded this as a transient phenomenon which would soon be outlived, and might there- 


\section{CHRISTIANITY AND POLITICS}

fore be neglected. It was not till after thirty or forty years of miserable suffering that the public conscience was roused to the fact that the industrial and commercial prosperity of the community was being purchased at the expense of the physical injury and moral degradation of men, women and children, and that the material prosperity might be purchased too dear. So far from its being true to identify the prosperity of the community and the prosperity of individuals it is safer to generalise from the experience of the early nineteenth century, and to say that the material progress of society, especially when it is rapid, involves a certain amount of individual suffering.

This seems to be a pessimist doctrine, and there is a temptation at the present day to fall into the old error, though from the opposite side. It is plausible to maintain that whatever is for the material good of the individuals who form the community, is also for the good of the community as a whole. But though it appears that national wealth consists of the sum of individual wealth, we are mistaken if we think of national life as consisting only of the aggregate of individual lives of the men and women of the country at the present time. We cannot identify the two and argue from one to the other, without falling into 


\section{RELIGION AND PUBLIC SPIRIT}

serious error, both in the interpretation of history and in the practical proposals we advocate. It is easy to show that individual suffering has again and again been incidental to the progress of society, and we may, if we choose, fix our eyes so earnestly on the individual suffering as to ignore the national progress. ${ }^{1}$ On the other hand, it is well to remember that what makes for the comfort of the masses in the present generation does not necessarily result in the material welfare of posterity in the long run. There are two points of view which must always be distinguished in our minds: the good of society on the one hand, and the welfare of the individuals who compose society on the other. While this distinction needs to be drawn even from an economic point of view, it is still more important to keep it in mind when we try to take account of culture and character and other elements in human welfare. Nor have we, in a progressive society, any fixed or definite standard by which we can judge of improvement, either in society as a whole or in individuals. We have not attained a goal from which to judge aright of each step in advance; we are only looking on at a process. We may, however, see that the national life and individual lives are closely interconnected and act and react on each other. The

1 Hammond, The Village Labourer, p. 26. 


\section{CHRISTIANITY AND POLITICS}

advance of society opens up more possibilities for individuals; and the individuals, who make the most of the opportunities that are open to them, are helping to secure each position that is gained, and are pioneers in social progress. 


\section{VI \\ HUMANITARIANISM AND COERCION}

\section{THE ABANDONMENT OF LAISSEZ-FAIRE}

IT had been generally held during the Middle Ages, and in the seventeenth century, that the man who thought only of his private interest was a positive danger to the community; but during the eighteenth century a remarkable change may be observed, at all events so far as material prosperity is concerned. At the beginning of the century according to current opinion the force of selfinterest was one that might be guided and controlled so as to work for the common good, and Parliament busied itself in the effort to bring private interests into harmony with that of the public. But as time passed, it came to be more and more recognised that State interference was not really as necessary as had been supposed for the promotion of public interests, and an era began when it was held that government would do most for the material prosperity of the country by leaving private interests alone. Adam Smith had reached this conclusion as a matter of practical experience, and from an examination of the 


\section{CHRISTIANITY AND POLITICS}

expedients by which statesmen had endeavoured to build up the material prosperity of Great Britain, while French economists expounded a similar doctrine as a philosophical principle. At the beginning of the nineteenth century, educated opinion in Great Britain accepted the principle of laissez-faire with confidence; men were inclined to believe that the way in which Parliament could do most for social reform was by abolishing the restrictions which had been imposed in less enlightened times. It was in this spirit that the Elizabethan arrangements for industrial training by means of apprenticeship and for regulating the rates of wages were swept away as anachronisms and absurdities. The present generation, after a century of laissez-faire, takes a different view of some of the institutions that were then abolished and does not regard them as either unnecessary or prejudicial.

In the second quarter of the nineteenth century there were, however, signs of a reaction, and it came to be generally recognised that State interference might be desirable in exceptional cases. Two causes contributed to this result, and so weakened the hold which laissez-faire had established on the public mind. First, philanthropists were conscious that their efforts to relieve distress were spasmodic and irregular; they felt that 


\section{HUMANITARIANISM AND COERCION}

the evils against which they were endeavouring to contend could not be effectively dealt with unless the State came to their aid; this was especially recognised with regard to the protection of children from injury. There might be a careful and considerate master with careful and considerate foremen, here and there; but philanthropic sentiment could not secure a change of system unless it were supported by the strong arm of the law. Again, the reforms which have taken place in the Civil Service itself have given the public confidence in official administration, to which it had no claim at the beginning of the nineteenth century.

The agitation which led to the appointment of a Select Committee of the House of Commons in 1830, and of a Royal Commission in 1833, revealed a state of affairs in the factory districts which convinced the public that State interference with some of the largest industries of the country was necessary; hitherto the public had taken for granted that individual suffering was merely transitional, but it now became plain that individual suffering, when cumulative and persistent, did serious mischief to the community. The public conscience was awakened by Mr. Michael Sadler and Lord Shaftesbury in regard 


\section{CHRISTIANITY AND POLITICS}

to the question of the employment of women and children, and this was taken up thoroughly. This was the first important step, but it led to many others; and a great advance was made in 1842, as the result of enquiries in regard to the employment of children in mines and in other dangerous occupations. The establishment of Factory Inspectors has done much to improve the conditions of work, by systematically calling attention to evils that can be remedied by State regulation, and to the improved forms of regulation which may be introduced. It is unnecessary, however, to follow out the story of this legislation; for our purpose it is sufficient to point out that the public conscience, when roused, succeeded in restricting the mischiefs which arose in connection with the industrial employment of capital.

Since the time of the Stuarts, all attempts to regulate by public authority the manner, in which capital was invested in industry, had broken down. The Church had failed to secure a response from the conscience of the upright man, in regard to the moral distinctions which were drawn; and the attempts of James I and Charles I to direct private capital into the channels in which it should best subserve public purpose, had been abandoned. Both civil and ecclesiastical author- 


\section{HUMANITARIANISM AND COERCION}

ity had been worsted in the seventeenth century in their attempts to control the great instrument of material progress; but the industrial revolution and the misery it entailed, despite the simultaneous increase of national wealth, forced the conviction on the public mind that capital could not be trusted with irresponsible power, but must be checked where patent evils had arisen. At that date, however, State interference was still regarded as an exceptional thing; and the onus probandi, in any further interference with laissezfaire, continued to lie with those who advocated restriction.

Since it was admitted that State interference might be occasionally necessary in the interests of the community, there has been a constant tendency to urge that a case has been made out for legislative regulation and official superintendence in some new direction. A very great extension of the principle occurred after 1831, when the outbreak of cholera caused a public scare, and drew attention to the conditions in which masses of the population lived. The most serious ravages of this disease, and of typhoid fever, had been in the Black Country and in the manufacturing districts round Manchester and Glasgow. A Royal Commission was appointed to enquire 


\section{CHRISTIANITY AND POLITICS}

into the preventable causes of disease, to consider how far improved drainage and sufficient water supply would contribute to a diminution of mortality, and what precautions should be taken in the case of noxious manufactures. Administrative machinery for dealing with public health was started in 1848, and progress was stimulated by the later outbreaks of cholera in $\mathbf{1 8 4 9}$ and 1854. The measures that were first taken tentatively, were only the beginning of an extraordinary development of governmental activity, which concerns itself not so much with the conditions of work as with the conditions under which people live. The growth of scientific knowledge has not only given us the means of curing what is injurious, but has rendered preventive measures possible. Progress has been made in many directions, especially as regards drainage and water supply, but the problem of housing both in urban and rural districts presents many problems that are still unsolved.

Such regulation in the interest of public health had only a very indirect bearing on the question of laissez-faire and the freedom of the capitalist to conduct his business in his own way, but there was a great deal of change of public opinion on this point. In the first quarter of the nineteenth century it was generally held that trade unions 


\section{HUMANITARIANISM AND COERCION}

were mischievous because they interfered with the freedom of the capitalist to carry on his business in the fashion in which he could make it a success. The limitations of hours, which had been urged by philanthropists for the benefit of women and children, operated so as to define the conditions of labour of every kind; and during the latter half of last century trade unionists have been able to secure the assistance of the legislature to carry out their policy. The right of collective bargaining has been recognised, and trade unions have been placed in a privileged position by the Trade Disputes Act, so that employers have difficulty in obtaining redress for injuries inflicted upon their business by their men. There has been at the same time a tendency to adopt, and to enforce, the principle of a minimum wage, which shows that the doctrine of laissez-faire in regard to the employment of capital and industry has been absolutely abandoned.

Laissez-faire had been first advocated by Adam Smith and his disciples with reference to the foreign trade, and they had a long continued struggle in order to secure its acceptance in this department of national economic life; but they may be said to have succeeded in 1846 when the Corn Laws were repealed by Sir Robert Peel. Even in 


\section{CHRISTIANITY AND POLITICS}

this connection, however, there have been signs of a reaction. The Fair Trade Movement of $\mathbf{1 8 8 0}$ was the precursor of the more vigorous agitation for fiscal reform, which was started by the late Mr. Chamberlain in 1903; and an immense amount is now done by the Commercial Department of the Board of Trade and in other ways for promoting commercial prosperity. ${ }^{1}$ Hence we are justified in saying that the policy of laissez-faire is no longer assumed as axiomatic, but has been completely discredited. It is very seriously called in question in those departments where it has not been already abandoned.

\section{COERCION AND THE DUTIES OF OTHER PEOPLE}

As public opinion was gradually awakened to the evils which had arisen under a system of laissez-faire, there was a new readiness to rely on the State and to recognise that certain conditions of life and employment were important to the community. It was felt that the State had a duty in regard to the overworking of women and children, and to the conditions of work and employment. Philanthropists were especially eager that the government should interfere and pass humanitarian legislation, and coercion by the State

1 Ashley, Preface to British Dominions. 


\section{HUMANITARIANISM AND COERCION}

seemed to be the simplest way of forcing other people to do their duty. What the better man would do voluntarily, and what was in the interests of the State in the long run, could not be adopted generally, so long as the shortsighted selfinterest of a few individuals was allowed to stand in its way. And hence philanthropists and humanitarians had a strong conviction in favour of coercion by the State; but while we recognise its merits, there is a danger of exaggerating the influence which it may exercise and of forgetting to take account of the conditions which are necessary for its success. It cannot be effectively brought to bear unless it is supported by public opinion, and even at its best there may be incidental disadvantages in relying on governmental machinery. Public opinion is more easily roused to demand governmental action in regard to any mischief than to the desirability of introducing positive improvements. The work of the factory commissioners, and of those who are employed in tracing evils which affect public health, and in insisting on such matters as the notification of disease, have been of the highest importance.

On the other hand, serious complications may arise when an attempt is made to confer benefits on the public at the expense of the rate- 


\section{CHRISTIANITY AND POLITICS}

payers or citizens. No improvement in material conditions will benefit all citizens alike; some sections or classes are likely to gain more obviously than others, and a proposal that fails to appeal to the sense of justice will not be taken up with any enthusiasm. A public park may be of great advantage to a civic community, but wherever it is placed it may be of constant advantage to some of those who pay for it, while others who reside at a distance will have little opportunity of enjoying it, and in this there is an element of unfairness; similarly it is possible that a boon may be conferred on men who cannot afford to take advantage of it; public holidays may be much enjoyed by those who are in comfortable circumstances, but the casual labourer cannot afford the luxury of being idle, and may feel it a hardship to have leisure imposed upon him against his will.

In other cases where the State by a system of Insurance insists upon compulsory thrift, there may be a legitimate grievance at having to provide for the future in the form, and on the terms, which the State lays down. Any pretension on the part of authority to coerce men for their own good is likely to be more or less resented among people in whom the sense of personal liberty is strongly developed. 


\section{HUMANITARIANISM AND COERCION}

Coercion by the State is a powerful instrument for dealing with masses of men, but it cannot be rightly adjusted to suit the circumstances of particular lives, and even as to the effects which will be produced upon society there may be much uncertainty. Those who are responsible for action by the State must give their minds to forecast probable results, and to deciding as to what it is wise to do under the circumstances. But no human legislator or body of legislators is omniscient. However well intentioned they may be, they are never perfectly informed, and social legislation is particularly liable to have incidental results that were quite unexpected; even in the case of transplanting some expedient from a place where it has worked well to another district, there is no certainty that it will be beneficial. The plot of garden ground that is ample in some conditions of soil, would be practically useless in another village. Experience which shows that a scheme is working well, as a means of facing a temporary difficulty, throws no light on the accumulative effects it may have in the long run, if it comes to be regarded as a permanent institution. The fact that the system of granting allowances in addition to wages staved off temporary distress in many quarters, will not lead us to commend the wisdom of a policy which resulted in such wide- 


\section{CHRISTIANITY AND POLITICS}

spread pauperisation. No hard-and-fast line can be drawn between the preventing of evil and the promoting of good, and no clear line can be laid down as to matters in regard to which the State ought or ought not to interfere; but it is clear that coercive authority is at its best, when it is aiming at eradicating some obvious physical evil, and that it is likely to cause much greater friction and to be much less certainly beneficial when it aims at conferring a general benefit, and a public boon.

\section{RELIANCE ON STATE INTERFERENCE}

A farther remarkable change in the attitude of the public mind towards State interference took place at the close of the nineteenth century. Up till $1880^{1}$ there was a general impression that State interference might sometimes be a necessary evil, but that it was so inconsistent with popular liberty that resort should not be had to it until all other methods of remedy had been tried. There was besides, in many circles, a feeling that government work was badly done; that officials were apt to be the slaves of routine, and that work was carried on more efficiently by private persons than by the State; State superintendence and inspection might be approved, but State

1 See my article on "Progress of Socialism in England," Com temporary Review, January, 1879. 


\section{HUMANITARIANISM AND COERCION}

interference continued to be looked upon with suspicion.

Towards the close of the century, however, a great impression was created by the success which had attended the remedial legislation in regard to the conditions of work in factories and mines, and the conditions of life of the working classes. The coercive power of the State was seen to be exceedingly effective in putting down mischiefs that had grown and flourished until it was brought to bear; an impression became widely diffused that, since this beneficent force was available, it was a mere waste of time to rely on feebler instruments for the redress of wrong. The change, by which private businesses were transformed into limited liability companies, was going on at the same time; and there was difficulty in maintaining the superiority of private enterprise in the face of the successes of these great bodies for associated enterprise whose organisation was similar in many respects to that of a department of State. Under these circumstances there was a sudden reaction; and many people, who had hitherto been suspicious of State interference, began to be enthusiastic for it as the best and practically the only method for introducing real improvement in the condition of society.

One of the results of the spread of this convic- 


\section{CHRISTIANITY AND POLITICS}

tion has been to stimulate the desire for obtaining political power, as it seemed that this gave the best means of removing social grievances. The fact of the success of the miners' agitation for an eight-hour day and of the demand of the trades unions for the passing of the Trade Disputes Act showed that a large section of the community could use their political power so as to give effect to their wishes for themselves. And this has stimulated the demand for Women's Suffrage, as it is widely believed that women cannot hope to obtain a redress for their grievances so long as they are excluded from political power.

There is a danger, however, of forgetting that State interference is a very rough and ready instrument, that a measure from which much was hoped is often disappointing in its working, and that any social legislation is certain to have incidental results which had not been foreseen, and which may be deleterious either to individuals or society.

In one direction, indeed, State interference may be positively injurious. When any duty is directly undertaken by the State there is apt to be a diminution of the sense of personal responsibility, and to be a discouragement to the discharge of personal duty. The standard 


\section{HUMANITARIANISM AND COERCION}

which the State can enforce is generally a minimum interpretation of what is right; and parents, who have kept their children at school for the minimum period enforced by the State, are apt to think that they have done all that is needed, and do not aim at anything higher. The payment of old age pensions by the State has been an enormous boon to many of the aged; but it appears to have diminished, and in some quarters to have extinguished, a sense of duty on the part of grownup children to do anything whatever for the benefit of their parents.

The danger of a decline in the sense of personal responsibility is most apparent in the industrial world. The capitalist - the employer who carries out all the conditions that are required by the factory inspectors - may feel that he is discharged from any obligation to take further consideration for the conditions under which his employees live and work; while it is abundantly clear that no increased sense of responsibility has grown up among the working classes pari passu with the increase of their political power. There is a lack of discipline either to their own leaders or to other officials, that does not promise favourably for the future. State interference is a crude instrument for conferring physical boons, and it seems as if it might be really injurious to personal 


\section{CHRISTIANITY AND POLITICS}

character. Whatever good it may accomplish among masses of men there must be other means of rousing higher ideals in individuals; personal ideals and personal effort initiate improvement that goes beyond what current public opinion demands. The State can at best only bring the laggards up to a level that is generally approved. Powerful as it is, where it can be applied, coercion by the State is never inspiring; we can hardly be kept up to the level we have reached, and we certainly cannot go beyond it, unless we can rely on a high sense of personal duty as well.

Humanitarians, who are most ready to have recourse to coercion within the Realm, are sometimes inclined to believe that it is possible to dispense with it altogether as between nations. They are deeply impressed with the horrors of war and believe that duty and interest alike render the appeal to it unnecessary: but, however the nations may be raised to a higher moral standard in future, a progressive society is likely to find difficulty in reconciling the keeping of promises with the desire of increased opportunities for progress; there is no immediate prospect that war will altogether cease in the near future. So long as any nation is in danger of being carried away by national greed and the desire to exploit other 


\section{HUMANITARIANISM AND COERCION}

countries, there is a risk of an outbreak of war; and hence there may be a duty for a country to engage in war, not merely to defend itself, but to maintain the peace of the world and to secure opportunities for human progress. In so far as there is a national duty, there is national disgrace in neglecting it. From a religious standpoint each nation is responsible to God for the power and opportunity it possesses, and this power and influence is not to be enjoyed selfishly, but to be employed generously and for the good of its neighbours. The people, who are content to look on and to watch the harrying of the weak by the strong, are guilty of selfish connivance at a crime, if they could have used their influence to prevent or to stop it. There is something of the spirit of Cain in seeking for an excuse for disregarding this obligation. To make common cause with those who are oppressed, or exploited by ruthless attacks, may be a duty, and in God's sight the neglect of a duty is a crime. In Old Testament times the selfish indifference of those who held aloof when they might have struck a blow against an invader, was bitterly denounced. Nations which do not use their opportunities aright are in danger of losing the prestige and influence with which they have been entrusted.

On the other hand, humanitarianism has not 


\section{CHRISTIANITY AND POLITICS}

always been ready to refrain from attempting to force other nations into improved conditions of life. Chivalrous attempts to coerce half-civilised or decadent governments may be generous and heroic, but they do not make for peace. The knight errant, who went about to redress wrongs, found plenty of occasion to pick a quarrel; and the nation, which feels free to champion the cause of oppressed humanity anywhere, may expect to be often embroiled with other peoples. Public opinion, which refuses to take up a quarrel unless there are definite grounds for it, is sound; and it is a Christian duty to avoid occasions for war in every possible way. Any country which is punctilious about demanding respect for her citizens and their rights may only be asking what is just, and yet be blamable for allowing the matter to become a cause of quarrel. Though it is not possible to stamp out war, it ought to be possible to refrain from giving way to national passion and to limit recourse to war to cases in which it is undertaken as the necessary means for securing public good, or righting a public wrong. Christianity goes further than mere humanitarianism in guarding against the occasions of war, while it has in the past set an example of trying by agreement to reduce the horrors of war; there is still need to make more generally applicable the prin- 


\section{HUMANITARIANISM AND COERCION}

ciples which the Mediæval Church enjoined in regard to private war. ${ }^{1}$ The truce of God was designed to limit the scope of war and to protect the civil population from its ravages; whereas it is sometimes urged in modern times that the most humanitarian course is to render war ruthless, so that it may be speedily over. But the Christian tradition as to the conduct of war has been extended by such agreements as the Geneva Convention and the Red Cross Movement. The principle that war, when it is necessary, should be conducted with a full sense of responsibility to God, applies not only to national action but to the personal character and conduct of the soldiers. All honour is due to the men who voluntarily risk their lives and submit to discipline, so as to be the instruments through which their country fulfils a duty. There is no profession which gives greater opportunity than soldiers have for cultivating the virtues of courage and devotion to duty, and the manly habits of chivalry, modesty and obedience. The civilian may pursue the routine of daily life in a Christian fashion, but the soldier may be inspired by his religion to conduct that is heroic. We cannot afford to ignore the teaching of the Middle Ages as to the conduct of war, and we have the means of bringing it to bear not only through

${ }^{1}$ See Appendix on the Attitude of the Church towards War. 


\section{CHRISTIANITY AND POLITICS}

knightly orders, but by international agreement and through the personal sense of what is honourable.

Just as we cannot rely on the coercive power of the State as the sole instrument of improvement within the country, so we cannot rely on the proposals made by humanitarians as sufficient for introducing a permanent remedy in international relations. Humanitarianism is excellent as a palliative in dealing with the symptoms of human passions which express themselves in war; but we shall make a grave mistake if we allow ourselves to suppose that because it succeeds as a palliative, it is making progress towards effecting a cure. Its diagnosis is defective, and the remedies it proposes are quite inadequate. It is shortsighted and fixes its gaze on the physical suffering of individuals, and neglects the real source of the mischief, in human passion and ambition, and the lasting effect on current opinion and feeling in a community. It concentrates attention on the dispute between one nation and another, and the possibility of adjusting their respective interests, and neglects the crime of breaking the public peace and the need of obtaining some guarantee against a repetition of the crime. The action it would propose is merely repressive - the ulti- 


\section{HUMANITARIANISM AND COERCION}

mate suppression of war by international authority, and in the mean time the limitation of armaments. But these suggestions are inadequate, and it is not easy to see how an authority could be built up which would inspire respect and enforce its dictates, and the supposed advantage which would ensue to the cause of peace from a reduction of armaments is illusory, though there would be a large financial saving if it could be carried through. But the expectation that by reducing the means of carrying on war there would be less danger of the outbreak of war, does not rest on any basis of fact; it is a mere assumption. The provision of apparatus for meeting the danger of fire, and the cultivation of efficiency in the organisation of the brigade, does not tempt the authorities of a town to set it on fire. There are no men who are more familiar with the horrors of war than the British soldiers; and the effort to make that army efficient does not lead them to endeavour to embroil their country with other nations. It is absurd to raise an outcry against a military caste, and to overlook the real causes of war in the national pride and determination to assert a national interest; from these democracies have no immunity. Humanitarianism lays the blame on the means of carrying on war, as if they were bad in themselves, instead of inculcating a sense of 


\section{CHRISTIANITY AND POLITICS}

responsibility in the use of them. In the same way, because nations have been organised for war, humanitarianism deprecates the very existence of nationality; it disintegrates society into a mass of separate individuals, with nothing to take them out of themselves, or to elevate them above the narrow life of dwelling on their own interests and indulging their own tastes. The love of country is the form in which higher and wider influences make their strongest appeal; the history of a nation is a continual source of inspiration from the past, and shapes the form which aspiration takes for the future. To attack national life, as if it were in itself evil, because it has become the basis of military organisation, is to abandon and destroy the most effective instrument for ennobling the people of any community, and for enabling them to bring a wholesome influence to bear on the world. In pinning its faith to changes in the conditions in which war has arisen, humanitarianism is shallow and superficial; it would limit the means of warfare, and break up any organisation which lends itself to war; but Christianity takes the more practical course by attempting to go to the source of the evil, in human hearts and dispositions. There is no hope of any thorough cure so long as we are content to look at conditions and means and organisation for warfare, 


\section{HUMANITARIANISM AND COERCION}

and do not seek to deal with the arbitrariness and passion in which it has its source. Christianity goes straight to the root of the matter; it seeks to eradicate the evil element in national life and thus aims at producing a complete cure.

\section{POLITICAL CHRISTIANITY}

Exaggerated reliance on the coercive power of the State has given rise to a new view of the nature of Christian duty. Those who are responsible for framing any legislative measures which may bring about social reform, have not an easy task in trying to carry them through. There are probably vested interests with which they may have to contend, and there is always a difficulty in overriding private rights in order to secure an admitted public benefit. It is also certain that there will be grave differences of opinion as to the best method of dealing with any particular evil; and those, who are fully convinced of the necessity of State action, may often be much divided as to the form which that action can wisely take. Under these circumstances the bold politician feels the need of extraneous help to strengthen his hands, and is inclined to believe that he has little chance of effecting his purpose unless it can be carried through on a wave of popular feeling. In this way Mr. Lloyd George appealed to a 


\section{CHRISTIANITY AND POLITICS}

gathering of the clergy of all denominations at Cardiff in October, 1911, and urged that it was their chief duty as Christian ministers to rouse the public conscience to the existence of some evil, so as to give ample support to those politicians who were endeavouring to devise a remedy and to bring it into operation through the coercive power of the State. He said he had come there to help to rouse a spirit that will compel every party in its turn to deal with these social evils; "and "that," he said, "seems to me to be the sphere of "influence of the churches, - not to support par"ticular parties, not to advocate particular meas"ures of reform, but to create an atmosphere in "which it will be impossible for anybody to re"main a ruler of the realm unless he deals with "those social problems. ... The first thing we "have got to do is to create a temper, a spirit, an "atmosphere that will compel men of all parties "to deal with these problems, whichever party is "in power for the time being. The responsibility "of the churches is this. The churches of Christ "in this land guide, control and direct the con"science of the community. No interest, how"ever great it may be, can long withstand the "resolute united opposition of the churches. "Public opinion in this land invariably responds "to the call of the United Churches. . . . He did 


\section{HUMANITARIANISM AND COERCION}

"not agree with the view that the Church was "concerned solely with spiritual things.... "Those who held this narrow view were false to "the traditions of the Christian Church. To-day "we had greater poverty in the land in the aggre"gate than we ever had. There was a more severe "economic bondage; for labour to-day was not "always guaranteed sustenance or security - a "condition of things foreign to the darker Middle "Ages.

"What was the function of the Church in refer"ence to social evils? The function of the Church "is not to engage in party brawls. It is not to "urge any specific measures. It is to create an "atmosphere in which the rulers of this country, "whether in the Legislature or the municipalities, "not only can engage in reforming these dire evils, "but in which it will be impossible not to do so."1

That a Cabinet Minister should express this view of the function of Christianity is natural enough. Many of the church-going public refrain from taking a very active part in party politics; but those voters, who cannot be counted upon to vote on party lines, may exercise a great influence in turning the scale if they can be induced to intervene; and pulpit addresses might be an effective means of reaching some of the doubtful

1 The Times, December 30, 1911, p. 5. 


\section{CHRISTIANITY AND POLITICS}

voters. It is a matter of surprise, however, that these views should have been received with enthusiasm in a large gathering of Christian ministers, since this new opinion assigns such a meagre place to Christian influence. This doctrine would have been indignantly repudiated by the leaders of any of the great religious movements since the Reformation; for the doctrine that the Church is only to be the handmaid of politicians, and to help them to carry on their work implies the degradation of the ministerial office. If the best that Christianity can do is to help the politician to carry through his crude measures for the benefit of the masses, the Church abandons the claim to inspire with high ideals, and to raise the tone of ordinary life. Neither the Presbyterians, who rated ministerial authority so high, nor the Independents, who were so eager to withdraw from the cares and entanglements of secular life, would have regarded the undignified rôle which Mr. Lloyd George assigns them as at all appropriate to the Christian ministry.

Despite his disclaimer, it may be doubted if Mr. Lloyd George really holds that ministers of religion should be content with creating an atmosphere. It is rather a futile occupation; for many years past there has been an active commendation of universal peace, and a propaganda against war- 


\section{HUMANITARIANISM AND COERCION}

fare. Fifteen years ago the Czar took an active part in promulgating such views through the Conference at the Hague: but the energy of national life demands scope for expansion; it is not to be held back by platitudes. The war in the Far East, the war in the Near East, and the ruthless invasion of Belgium, are striking illustrations of the ineffectiveness of the solemn enunciation of humanitarian sentiment.

To produce the desired result, it is necessary not only to create an atmosphere, but to agitate it into a gale. Such agitation must almost necessarily involve the clergy in active participation in party politics, by signifying approval of the measures of one party, and denouncing the neglect of the other. Party government is, on the whole, the method by which action can be taken in democratic communities. Its disadvantages are obvious, though it has many merits which may easily be overlooked; both parties are agreed on the aims they pursue for the good of the community; they differ as to the means which it is wisest to adopt at any place or time, and as to the relative importance of certain courses of action. In all political action moral questions are involved, as to the bearing of proposed changes of the law on human relationships. There is no 


\section{CHRISTIANITY AND POLITICS}

proposal with regard to the material welfare of the community which does not affect individuals personally; but fanaticism fastens on the moral element, in particular questions, and treats it as if it could be isolated so as to be the sole issue. The ministers of religion, who at any time feel it a duty to bring their influence to bear in favour of the measures proposed by one particular party, ${ }^{1}$ are liable to the temptations which beset all those who are engaged in political agitation, of using exaggerated language which may neither be strictly true nor wholly charitable. Indeed the preacher who makes an occasional incursion into the sphere of party politics is in greater danger of becoming a partisan than the practised political speaker, who is habitually on his guard. The man who feels that he is advocating a great moral cause, is in danger of doing it fanatically, and of disregarding any questions that are raised as to the wisdom and probable results of the particular measures proposed. The clergy, who are habitually thinking, not of the results of action, but of the motives which lead to it, are particularly apt to attribute interested motives to their political opponents, instead of contenting themselves with arguing as to the wisdom or unwisdom of the measures proposed.

${ }^{1}$ Cunningham, The Cure of Souls, p. 186. The Clergy and Party Politics. 


\section{HUMANITARIANISM AND COERCION}

The relative merits of Free Trade and Protection have been a subject of constant discussion in Great Britain for the last twelve years. Like other political questions it seems to be in part a question of expediency; the Tariff arrangements which are best for a community at one time, may not be best at another; and that which is best for one country may be injurious to another. But in 1904, when this question had become the main issue at one or two by-elections, several eminent ecclesiastics felt it a duty to throw themselves into the fray with fanatical zeal. They contemptuously brushed aside the "salient details" in regard to the economic questions as "superficial discussion," and called attention to "certain fun"damental judgments ethical and social" which seemed to them "to be profoundly involved "in the issue." It will not then be deemed "impertinent or intrusive," they say, "if those "who are charged with any special responsibility "for the national conscience venture to detach "and emphasize these essential considerations "which are vital to the verdict that is to be given." They therefore invited additional signatures to a declaration in which they denounced a system of Protection, because "in itself it inevitably tends "to evoke the motives and foster the tendencies "against which we are all accustomed to protest 


\section{CHRISTIANITY AND POLITICS}

"as immoral. It cannot succeed without increas"ing the severance of nations; it intensifies rival"ries and strengthens barriers; it is a foe to peace, "and to the hopes of a wider unity of workers. "No nation can adopt it without danger to the "uprightness of its public life; it makes bribery "pay; it creates monopolies; it opens the door of "Parliamentary lobbies to all those influences "which it is our main object to exclude. It is "bound by its very conditions to tell hardest "against those who are least able to protect them"selves." 1 When we remember how recently Great Britain has abandoned a protective system, it is not easy to be patient with this disparagement of our countrymen in previous ages; neither France, Germany, nor the United States, not to mention our own colonies, can be expected to take this claim on the part of Free Traders to superior virtue quite seriously.

The moralist is in some danger of falling into shallow cynicism, when he denounces motives which are gratuitously attributed to opponents, instead of contenting himself with considering whether his own opinions are well founded or not. He professes, too, that he does not take part in public affairs regularly, but only when he sees that a moral question arises; but he may be guilty

1 Guardian, 23d November, 1914. 


\section{HUMANITARIANISM AND COERCION}

of introducing this element of bitterness and of lowering the whole tone of public discussion. It is specially to be feared that the Christian minister who feels called upon to use the pulpit for political agitation, is going outside the terms of his commission; he has a trust imposed upon him, and it is his duty to declare the eternal truth which has been revealed to man by Our Lord. But in connection with the passing of any legislation the questions which arise are chiefly matters of expediency, and of forecasting the probable results of the measure. These are at best matters of opinion. The preacher's opinion may be a good opinion, or it may be a mistaken opinion, but it has no pretensions whatever to be a declaration of Divine Truth.

The seventeenth-century Calvinists endeavoured by means of Ecclesiastical Courts to coerce men into conforming to a godly polity over every part of which scriptural authority could be claimed. The Neo-Calvinists, with modern ideals of what a polity ought to be, are inclined to invoke State aid to bring pressure upon other people so as to force them to do their duties. Humanitarians are often content with pointing out the neglects of other people, and with saying they should be forced to live up to a different standard. It is 


\section{CHRISTIANITY AND POLITICS}

unfortunate that so much Christian energy should be directed into channels where newspapers and public meetings can act more effectively, and should be diverted for the special work, for the welfare of the community, which Christianity can do, and which is in danger of being neglected if Christians fail to undertake it. The coercive power of the State is effective within certain limits, but it has limitations: it can put down patent evil, and thus improve the condition of the masses. It can even coerce so as to bring the general level of life up to a given standard, but it has very little power of taking an initiative or acting as a pioneer. This can be best done by individuals; and the history of social improvement of every kind shows that individuals, who cherished a high ideal or had a strong sense of duty, have made a new departure which public bodies have been gradually persuaded to follow. While the State is powerless in this matter and may even narrow the scope of individual action, Christianity can bring an enormous influence to bear on individual lives personally. It can set before them high ideals for human life both personally and socially, and it can stimulate a sense of duty. This is the special work which Christianity has done in the past, and is doing at the present day, and there is no other 


\section{HUMANITARIANISM AND COERCION}

doctrine which can claim to do it more effectively. Christianity need not content itself with merely aiding in the coercive activities of the State, since it can supplement these activities by influencing individuals in a fashion that the State cannot attempt. 


\section{VII}

\section{CLASS INTERESTS AND NATIONAL INTERESTS}

I. SUBSTITUTES FOR THE SENSE OF DUTY

THe nineteenth century had awakened England to a sense of the danger of giving free play to egoism and individual interest, and to recognise that it might be necessary to introduce coercion for the sake of the community as a whole. On the other hand, more and more stress was laid on the growth of class interest; many workingmen began to look beyond their own immediate surroundings; they endeavoured to take account of a longer prospect than their own lives, and to have regard to others who were situated similarly to themselves. The associations of men for common objects have had a very high value; but for this very reason there seems to be a danger of exaggerating what they can accomplish, and of looking on loyalty to an association as if it could be a substitute for any deeper sense of duty. The principle of association is deeply rooted in English soil; the guilds of the Middle Ages can be traced back to very early times, and survivors of them still exist. It may be said, however, that on the whole 


\section{CLASS AND NATIONAL INTERESTS}

mediæval guilds existed to carry out common duties, - either in regard to religious conduct, or in insuring that industrial callings were practised in such a fashion as to promote the good of civic communities. Again in the eighteenth century the societies to which allusion has already been made, were founded chiefly for the purpose of supplementing the efforts of the State in discharging public duties. The nineteenth-century associations have, on the whole, been of a different character; they have been formed by groups of men who desired to promote certain interests which they had in common, and they have brought about a great change in the condition of the working classes, not only on the material side, but intellectually and morally as well.

One of the greatest difficulties with which the labouring classes had to contend during the Long War arose from the high prices which they were charged for goods, especially in cases where they were far from a town, and were compelled to deal at one particular shop. With the view of meeting this difficulty a village shop was established on co-operative principles in Mongewell in Oxfordshire in 1797, and its success was such as to secure the attention of philanthropists. Not much came of the matter, however, for nearly thirty years; till a similar experiment was made at Rochdale by 


\section{CHRISTIANITY AND POLITICS}

the Pioneers; and since that time the co-operative movement has developed in other directions, so that there is an enormous network of stores in which the trading is carried on by means of capital formed by those who deal at the shop, and on terms on which the consumers of goods get the full benefit of the profits in their own retail trade. Besides the saving thus effected, and the improvement in the quality of the goods supplied, there has been a gradual development of esprit de corps in the consciousness of combining with many others for a common object; while the carrying on of the business of these societies is very educative, from the number and varied nature of the interests with which these societies are concerned.

Robert Owen, who had managed a cotton mill at New Lanark, formulated a new view of society which seemed to open up immense possibilities; he recognised that the interests of capital and labour were the same in the long run, and he endeavoured to carry on the cotton manufacture on the principle of inducing all who were concerned in his mill to devote themselves to this common interest. For some time the business prospered, but his subsequent experiments at Orbiston and New Harmony in Indiana, were never successful. He had, however, attracted an immense amount 


\section{CLASS AND NATIONAL INTERESTS}

of attention, and had succeeded in creating the impression that there was a great future before the principle of co-operation in the organisation of production. Since his time there have been many experiments in copartnership; notably one in coal mining at Messrs. Briggs' collieries in 1865; and though there has been much discouragement at the slowness of the progress, there is an increasing circle who have confidence in the movement. Very striking successes attended the efforts of Sir George Livesey to introduce this system into the South London Gas Works, and he seems to have overcome the difficulties in a business carried on under special conditions. As there are comparatively few fluctuations in the output, the circumstances of the business are special, and there are other trades in which it may be impossible to make any change of the kind. But even if it cannot be regarded as a panacea, the principle of association may be so introduced as to ease the strain in the relations of capital and labour, and to secure a real gain where it proves successful.

The Friendly Society Movement is another application of the same principle; many such associations were formed in the eighteenth century, and they obtained important status from the Act for 


\section{CHRISTIANITY AND POLITICS}

the Encouragement of Friendly Societies which was passed in 1793. They fell under a cloud at the beginning of the nineteenth century, when political conditions roused public suspicion in regard to the purpose of Working Class Associations, but they have outlived this suspicion. The Manchester Unity of Odd Fellows has had a prosperous career for more than a century, and the Foresters and Hearts of Oak are also great national institutions. There have been hundreds of village clubs which have devoted themselves to the same work of encouraging men to combine to ensure against the pressure of occasional stress from illness or unemployment. It is perhaps the greatest compliment which these societies could have earned that so much of their work has been taken over under the Insurance Act of 1912: though it may be feared that government routine will hamper individual initiative and prevent the growth of esprit de corps.

Most remarkable of all has been the growth of trade societies in which men have combined to maintain a common standard of life. The members of trade unions have been brought into conflict with employers at many different points, but their aim through it all has been the maintenance and improvement of their standard of life. They have done excellent work, that is hardly heard of 


\section{CLASS AND NATIONAL INTERESTS}

by the public, in bringing cases where the law has been neglected under the notice of inspectors, and in checking malingering and assisting in carrying out the Compensation Acts fairly. The organisation of labour has proved on the whole a convenience in large businesses which have outgrown patriarchal methods of management, though friction has arisen and is likely to arise over the policy which the unions sometimes pursue. Where they have attempted to secure a benefit by restrictive methods that raise the price of goods to consumers, their action has interfered with the development of their own industry and been injurious to their own class. But even when occasional errors of judgment are taken into account, the beneficial influence they have exercised has been very remarkable. They have called forth a strong esprit de corps, and have awakened among their leaders an earnest desire to take an active part in the government of the realm, and thus to maintain the important interests for which they are banded together.

\section{INADEQUACY OF CLASS INTERESTS}

The co-operative movement, which rests on the principle of association for the pursuit of common interests, has received a cordial welcome in many quarters, and has roused the most sanguine ex- 


\section{CHRISTIANITY AND POLITICS}

pectations. The advocates of laissez-faire and of freedom for the individual felt that this movement was, at any rate in its beginnings, entirely consistent with the doctrine to which they were so much attached. The individual was wise to combine with other men to advance their interests, so long as they did not inflict injury upon others or the public; and the co-operative movement, which had the effect of cutting down monopolists' gains and securing a better supply of the necessaries of life, was a form of self-help with which they could heartily sympathise.

Co-operation also met with the approval of those who were enthusiasts for education. The very essence of the system lay in helping men to have a more intelligent understanding of their own interests; not to be content to live from hand to mouth, but to consider by what steps they and their fellows might improve their position in the long run. The leaders of the co-operative movement from the first realised this so strongly, that they set aside a portion of their trading profits for educational purposes; they recognised that the greeds and passions of the moment were enemies with which they had to contend, and that the progress of their movement involved the cultivation of enlightened and rational self-interest. 


\section{CLASS AND NATIONAL INTERESTS}

Further, there were eminent men who recognised that the co-operative movement was consonant with the teaching of Christianity, that men learnt, in pursuing a common rather than a private interest, to think not only of their own things, but also of those of others. In the "forties" Maurice and Kingsley threw themselves heartily into advocating the movement, not only by writing Tracts for the People, but by the experiments which they started; and in the "eighties" Bishop Westcott cherished high expectations of the results which might be obtained through the further progress of co-operation.

At the same time it is to be feared that these hopes are somewhat exaggerated, and that the principle of association for promoting common interests will not suffice to solve the practical difficulties of the day. It does not foster a sense of duty to the community, but aims instead at securing objects which men have in common, and at satisfying wishes of which they are conscious. All can realise the benefit of obtaining better goods at lower prices, or the advantage of securing themselves against unforeseen emergencies; they can easily understand the good which may accrue, if not to themselves to their children, from anything that is done for raising the 


\section{CHRISTIANITY AND POLITICS}

standard of living. But although it is true that all the citizens are interested in the prosperity of the nation as a whole, it is yet true that the advantages are so distant, either in place or time, that it is difficult for the individual to realise them at all, and that they do not appeal to him. He may be shocked to hear of inhumanities in distant lands, but he does not see that they are his affair, or that he can help them; and he may be interested in forecasts in regard to posterity, but he does not find them convincing or take them to heart. He is in danger of ignoring the duties of the community except in so far as he and his neighbours are concerned. A political society built on the model of a voluntary association for the pursuit of common interests can hardly take into account the far-reaching influence on the world, or on its own future, which may be exercised by a great polity.

The possibility of pursuing class interests in such a fashion as to be injurious to the nation ought to be taken into account, for it may frequently occur in actual life. Class interest, like individual interest, may fail to promote the common good. The question whether any body of men are pursuing their interests in a fashion which is injurious to the community as a whole, cannot be easily decided. In the early years of 


\section{CLASS AND NATIONAL INTERESTS}

the nineteenth century educated opinion was unanimous in the belief that associations for improving a standard of comfort for the labourers by securing an advance of wages were injurious to the community as a whole, and that the injury was sure to react severely on the position of those who relied on such mistaken means. Dr. Chalmers repeated the typical opinion of the religious and charitable men of his day, and legislators endeavoured, with imperfect success, to stamp out such combinations altogether. In England in 1906, public opinion had so entirely changed, and there was such a general consensus in the belief that trades unions were wholesome elements in the organisation of industry, and especially beneficial to their members, that they were put in a position of privilege by the Trade Disputes Act. But more recent experience has raised the question afresh as to whether their objects, and the manner in which they pursue them, are in real accord with the good of the community as a whole. This case at least illustrates the possibility that one section of the community may conceive of their own good, and may pursue it, in such a fashion as to be injurious to the community in the long run.

There is another point on which the opponents of combination for trade purposes, in the begin- 


\section{CHRISTIANITY AND POLITICS}

ning of the nineteenth century, laid stress. There may be a conflict not only between a class and the community, but between the interest of the class, on the whole and in the long run, and that of the individuals who compose it. There is an importance in providing conditions that are favourable to the development of the individual, and to his enjoying the fullest life possible. Individualism may be so pursued as to promote anarchy; but on the other hand the interests of a class or the community may be treated as paramount, so that no adequate scope is left for individual self-development. Where personal interest conflicts with the interests of the class, and a man likes to sacrifice his individual interest voluntarily, his conduct is public-spirited and admirable; but if the sacrifice is demanded from him against his own judgment and enforced by external pressure, there is a danger of the establishment of a new tyranny. When the principle of association involves a lifelong agreement it leaves no room for a change of mind under changed circumstances, and it needs to be corrected by some guarantee for personal liberty. The freedom of the trade unionist in regard to the political action of the association to which he belongs has been a burning question in recent years. 


\section{CLASS AND NATIONAL INTERESTS}

\section{NATIONAL INTERESTS}

It is becoming increasingly difficult to cherish the hope that personal interests and class interests will be reconciled by associations, and it seems still more improbable that national interests will freely co-operate for the good of the world as a whole. Undoubtedly war is the greatest evil from which human society at present suffers: not only is there the horrible destruction of human life which it involves, but the waste of resources and the widespread poverty which follow in its train. Politicians fear that the rivalry in armaments must sooner or later result in the bankruptcy of one or more of the great nations of the world; and attempts have been made to show that each would gain in material prosperity by entering into an agreement to refrain from war in the future. The argument obtains more force when it is remembered that a community consists of many individuals; it is plausible to say that for the country to go to war is not in the interests of private individuals, unless in the possible case of army officers or army contractors; and hence it is argued that if the aggregate voice of the mass of the people could make itself effectively heard, wars would never break out. But there is little evidence in support of this contention; the repub- 


\section{CHRISTIANITY AND POLITICS}

lican States-General were not less militant in the seventeenth century than the British monarchy. A democracy may be very ready to take offence on slight provocation, and a democracy is apt to resent being bound by old agreements in which the present generation have no voice. During the hundred years' peace between Great Britain and the United States it is difficult to see that the thorough-going democracy has been more careful than the monarchy to act as a good neighbour and to avoid occasions of irritation.

Mr. Norman Angell and his followers have attempted to prove that it can never be in the interest of any nation to go to war, and that it would therefore be to the interest of each country to refrain from putting forth its full strength in anticipation of war, and to trust instead to agreement between nations. Apart from the diffculty of framing an agreement that should continue to be applicable, and binding in the changing conditions of national life, there can be no confidence that an agreement, which rests on interests, will not be broken whenever it becomes the interest of any of the parties concerned to throw over the others. In the Middle Ages the Church endeavoured to play the part of an international authority which could back up its deci- 


\section{CLASS AND NATIONAL INTERESTS}

sions by spiritual censures; but there seems little reason to hope that an international agreement would be permanent when there was no effective means of immediately enforcing it. So long as national ambition exists, and nations are prepared to push their own interests unscrupulously, it would be reckless for any country to allow its very existence to become dependent on the complacency of its neighbours.

While attempts to avoid the horrors of war by arbitration and agreement are to be eagerly welcomed we make a mistake if we regard them as more than temporary expedients. They do not in themselves effect any permanent cure, because they do not get rid of the rivalries which bring about international quarrels. Warfare is only one of the forms in which national jealousies express themselves; national ambition and the greed of private persons within the nation have shown themselves again and again in deliberate attempts to exploit other countries and to enforce them to remain economic dependents and thus to be in danger of political subordination. Jealousy of English commercial greatness was one of the causes of the Napoleonic Wars; "commerce, though it "was truly one of the greatest earthly blessings " which God bestows, and is even the chief instru"ment which He employs to bind the nations of 


\section{CHRISTIANITY AND POLITICS}

"the earth together, has nevertheless, it must be "owned, a tendency in itself to produce this insa"tiable appetite of accumulation, and we cannot "be ignorant that other nations reproach us per"petually with what they call the unfair and un"reasonable extension of our commerce. Nor do "they scruple to tell us that the lust of commerce "is as great an enemy to the peace of the world as "the lust of empire." 1 A generation later, when Great Britain had been enormously successful in developing her manufactures, there were Englishmen who hoped that her industrial supremacy would enable her to dominate the markets of the world and to keep less progressive countries in a condition of economic dependence. ${ }^{2}$ A free trade policy was successfully advocated as a means of attaining this power of dominating the world economically. Had the countries of the world been willing to sacrifice themselves an era of universal peace might have ensued, but those who anticipated its immediate advent did not foresee that great communities would be unwilling to sacrifice their own material development. The scientific advance of Germany and her skill in organisation has enabled her to become the successful rival of Great Britain industrially and to

1 W. Carey, Bishop of Exeter, Sermon (preached before the House of Commons, 1809), p. 13.

2 Cunningham, Case against Free Trade (2d edition), p. 141. 


\section{CLASS AND NATIONAL INTERESTS}

make a bid for economic dominance on which world-power may be successfully based. With changing degrees of development, as well as through the exhaustion of natural resources, the enonomic relations of different countries are constantly changing, their interests do not remain the same; but the experience of the past gives little ground for the assumption of doctrinaires that consciousness of economic dependence is a condition which necessarily favours international friendship.

Neither welfare within the nation nor universal peace throughout the world can be securely based on the play of class interests and national interests; concentration on material prosperity will never cure the evil that arises from overvaluing the material side of life. No readjustment of political maxims within the nation, and no creation of new machinery throughout the civilised world, will itself do away with jealousy and greed. The consideration of interests can never be a substitute for a sense of national duty and of personal duty; these deal directly with the cause of the evil and may thus effect a permanent cure. Both in the world at large, and in different countries where the sense of the duty of the community and of duties to the community is imperfectly understood, there is a danger that powerful inter- 


\section{CHRISTIANITY AND POLITICS}

ests will encroach on individual liberty, and there is little hope of progress in society. We cannot rely on the material prosperity of the community as a whole, still less on that of any section of the community as a proof that life is healthy. It is indeed difficult to find a test by which to judge of the good and bad in the national life of progressive communities. No formula, either economic or moral, lies ready to hand and enables us to give a definite judgment; there may be great differences of opinion in the interpretation of righteousness and justice at any given moment, and even if the principle be clear, the difficulty of forecasting results or interpreting motives makes it difficult of application. The most trustworthy guide as to the good or evil of the life of a community is afforded by the personal life and character of the citizens who compose it. If they have a strong sense of duty and a patriotic enthusiasm there is not likely to be much amiss with the community. On the other hand, the political character and good citizenship of the individuals is most obviously displayed when it is seen on a large scale in the conduct and character of the community which they constitute at the time.

A body of self-interested individuals cannot help forming a sordid polity; they are brought together by a consciousness of their own interests, 


\section{CLASS AND NATIONAL INTERESTS}

and the main motive of each is apt to be, to see that he gets his share out of the common benefit. This is the attitude of mind which leads to corruption on the part of officials and which induces powerful sections of the community to feel justified in condoning unfairness on the part of administrators or legislators. Those who are advocating real improvements may be tainted by this spirit. They may recognise that the public improvements cannot take place except at individual loss; they are ready to insist with Mr. Birrell, that minorities must suffer, but they will be at pains to see that someone else does the suffering, and that they are not called upon to sacrifice themselves.

A polity composed of individuals, associated for their own interests, cannot hope to have much influence for good on the world; it will be content to be self-centred and to live its own life in splendid isolation; it will have no sense of duty to its neighbours except that of setting them an example, and no care for humanity at large. Such a polity is not unlikely to measure itself or others by a sordid standard, and to be guilty of dishonourable conduct. Where considerations of interest are strongly felt and opportunities are favourable, the promises embodied in solemn treaties are likely to be worthless, as we have seen in the 


\section{CHRISTIANITY AND POLITICS}

annexation of Bosnia by Austria, and in the German invasion of Belgium. For the welfare of the world it is not only important that a nation should be as good as its word, but that friendship between nations should be a reality, and that a national obligation to sacrifice something for a friend should be admitted. The main obstacle to the peace of the world at the present day is due to the manner in which national interests are allowed to obscure the sense of national honour. A political system which rests on a mere consideration of interests fails to offer scope for individual development or to hold out hope of nobler national life. 


\section{VIII}

\section{CHRISTIAN DUTY IN A DEMOCRACY}

\section{MODERN PERPLEXITIES}

Our survey has shown that there is little hope that religion can be effectively brought to bear on political life by external authority. The attempt to do so was one great occasion of the revolt against the Church of Rome, and the pretence to mould political life on a scriptural model was never acceptable to Englishmen when it was attempted by Presbyterians. From the time of Locke onwards there has been an increasing tendency to regard secular welfare and civil right as the matters with which the State has to deal; and to disclaim any public duty, not indeed of acknowledging religion, but of maintaining and fostering it. A man's belief is generally regarded as his private concern with which no public body should interfere. The Anglo-Saxon peoples are inclined to boast of the religious toleration which exists among them; and this may be interpreted as meaning that the government, as a government, is for the most part, indifferent to religion. The provision of chaplains for the Army and 


\section{CHRISTIANITY AND POLITICS}

Navy and of chaplains in workhouses is quite exceptional, and hardly affects the truth of the general statement. The public, on the whole, think that the introduction of religious questions into political life is a disturbing element which is at once irrelevant and confusing, and that civil legislation and administration go on more smoothly when this cause of possible friction is eliminated altogether.

Still, the effort to carry on the government of nations and the organisation of society on lines in which religion is ignored, while successful up to a certain point, has not been altogether satisfactory. If we fall back, like the seventeenthcentury Quakers, on purely mundane considerations for civic affairs, we are compelled to look for guidance either to human sentiments or to human interests; but neither can be trusted absolutely and completely. Humanitarianism has done much; but the field where coercion is applicable is limited, and it does not give much hope of progress for the future. While the appeal to interests is always powerful, there is no security that there will be any stability in the institutions which rest upon it. In a modern democratic community there are facilities for securing the welfare of the community such as never existed 


\section{CHRISTIAN DUTY IN A DEMOCRACY}

before. With popular representation there is a possibility for obtaining a full knowledge of public requirements, and throughout Great Britain there is widespread political interest. This is largely due to the manner in which departmental administration is ramified, till government interference touches such masses of people in the conduct of their affairs and the conditions of their life. Yet there is a wide-spread feeling of unrest, and complaint is being constantly made of the whole social fabric. There are many socialists who insist that the edifice must be re-built from the foundation, and anarchists who desire that the foundations should be re-laid, in order that we may see more clearly where to begin to build. But the new foundation is not far to seek; though there may be an intellectual difficulty in showing how the various elements may be combined, there is no practical difficulty in proceeding with the work. The one great need is the cultivation of a personal sense of duty, so that each citizen shall live his own life in the fashion in which it may contribute most to the service of his country, and through his country to the good of the world. The democratic citizen has a voice in directing the life of the country, and he also leads a life of his own. In so far as his sense of duty comes to bear in either field of action, he 


\section{CHRISTIANITY AND POLITICS}

is able to bring the force of sentiment and the force of interest into co-operation. The free man is not necessarily carried away by either one or the other; but he is able, as opportunity is afforded him, to bring both into play.

Christianity had much to do with the awakening of public spirit in the eighteenth century, and it has a unique power for maintaining and fostering the sense of public duty to-day. Where authority ends influence begins; and Christianity will work along the lines of least resistance if it appeals, not to society as a whole or to men in masses, but to individuals personally. The experience of centuries in the past, and of earnest Christians in the present day, furnishes overwhelming testimony to show that an influence may be brought to bear on personal habits of thought, which will affect all a man's activities both in his private relations and in his public duties. This influence is spiritual, both because of the insensible manner in which it operates, and of the various directions in which its effects may be shown. There is no element of compulsion about it, as it is not enforced either by civil authority or ecclesiastical censures; it appeals directly to the personal will of the individual man or woman, and by means of an attractive force; the influence from each of these personal centres 


\section{CHRISTIAN DUTY IN A DEMOCRACY}

may ramify in so many directions as to permeate and gradually to transform the whole of society politically and economically. This is the method of working which seems to be in closest accord with our Lord's instructions in regard to the Kingdom of God. He speaks of it as planted within; and illustrates its effect on society by the salt which can prevent corruption and the leaven which may work through the whole lump. There was with Him no suggestion of enforcing a code on a newly constituted society, but of planting a spiritual power which might transform the kingdoms of the world.

The Christian man, who desires to do his political and social duties, may well be oppressed with a sense of the stupendous task that lies before him, and confused as to the manner in which he can best set to work. The world is so evil, the mechanism of modern society is so complex and remorseless, that there is a temptation to shirk the responsibilities altogether, and to plead that if he tries, he may do more harm than good. But this faithless habit of mind is inexcusable, and our Lord warns us against it again and again. The servant who, out of a false humility, or because he was remiss, hid his talent in the napkin was severely punished: we are bound as Christians to make the most of our opportunities whatever they 


\section{CHRISTIANITY AND POLITICS}

may be. The warning is constantly reiterated, but it is put most strikingly in the parable of the sheep and the goats, where readiness to use opportunities of service is so wonderfully commended, and the wickedness of those who neglect them is condemned.

There are two fundamental principles which cover Christian duty in all the relations of life. The sense of his responsibility to God for the use of his time, and of his responsibility as a trustee for the use of the possessions he holds, should control the Christian in his manner of using them; while the recognition of these responsibilities to God helps to throw light on the duties he owes to his fellowmen. From the responsibilities in regard to time there follow the duties of work, and of diligence while at work. This is a duty which is incumbent on all Christians whatever their circumstances may be. Some are compelled by the stress of need and desire of independence to work at a calling which brings them a reward; while those who enjoy an independence are free to choose the work which they think they can do best; but on all there is the same duty of diligence; "Whatever thy hand findeth to do, do it with thy might." The sense of this responsibility will foster habits of 


\section{CHRISTIAN DUTY IN A DEMOCRACY}

self-discipline. A warning is needed against frittering time away in pastimes which are not really recreative, and which do not confer pleasure on others, so that they have no beneficial result on any human being.

The other principle, of responsibility for possessions and the sense of trusteeship in using them, is to be borne in mind as a help to avoid recklessness and waste, as well as greed and oppression. No man has a right to gamble, and run the risk of losing the wealth which has been lent him for a time; and no man has a right to use the power which wealth gives so as to oppress his fellowmen. These are the principles of selfdiscipline which a Christian is bound to keep before him; they are far more fruitful than the prudential maxims in the Proverbs. The Christian character is modelled on the belief that man is called upon, not merely to obey a Divine Code imposed at Sinai, but to co-operate, in each new age, for the regeneration of mankind. A few words may serve to point out some of the ways in which this sense of responsibility can operate, and to show how spiritual influence, working in the individual heart, may be brought to bear on national life in its political and economic aspects. 


\section{CHRISTIANITY AND POLITICS}

\section{DUTIES AS A CITIZEN}

There is a very strong temptation to many men at the present day to refrain from taking any part in political activity. The reasons that are alleged by those who desire to excuse themselves are plausible: they see the futility of much political discussion, and are tired of the mutual recriminations of political parties. They see no great difference of principle between one party and the other, and they are ready to suspect that the members of each are simply playing for their own ends, and not specially concerned for the good of the country. Personally, I believe that these charges are grossly exaggerated, and that, on the whole, the party leaders have thrown themselves into political life, often at considerable personal sacrifice, because they were anxious to help in carrying out measures which they believe would tend to the good of the country materially and morally. That there may be decided differences of opinion as to the method which it is most wise to adopt, having regard not only to the present but to the probabilities of the future, is true enough. That there may be differences, too, as to the relative importance of one particular step or another is also true. That a man's opinions on these points are likely to be affected by his special 


\section{CHRISTIAN DUTY IN A DEMOCRACY}

circumstances and his forecast of his personal interest and of that of men who are situated as he is, is undoubted; but this is no sufficient ground for cynically asserting that the opinion is dishonest, though it is a reason for criticising any policy carefully.

With all its defects, party government is the method by which government is likely to be carried on in democratic communities. Its defects are to a large extent the price which must be paid for the liberty which democratic citizens enjoy. When power is widely diffused, there must be uncertainty about the formation of decided public opinion, and difficulty in shaping measures by which that public opinion is brought into effect. Party government is the best instrument which has yet been devised for carrying on the affairs of State among a free people; and it is by finding out the party with which he most strongly sympathises, and with which he can work most cordially, that any citizen may bring his individual opinion to bear most effectively on the course of national affairs. The man who tries to be independent of party condemns himself to mere futility; or, at the best, he becomes an opportunist who tries to see what help he can get, from each party in turn, in advancing the cause in which he is interested. This is not a dignified attitude to take; and it 


\section{CHRISTIANITY AND POLITICS}

only attracts the men whose judgment is so one-sided that they are devoted to one particular element exclusively, and are indifferent to the good government of the country in all other respects.

All the action taken by the State is necessarily political; it is concerned with the defence of the realm from without, the administration of justice, and the maintenance of good order within. The manner in which the duties of the State are discharged is of the highest importance, not only for the present generation but for posterity; the mistakes of one generation are visited on their children and children's children. The man who is so careless that he excuses himself from doing his best to understand political questions, and to give an intelligent opinion upon them, is unworthy of the privileges of citizenship, and cannot escape his share of blame for any mischief that he might have helped to prevent, if he had been unselfish enough to take trouble in the matter.

The political influence of a nation offers the means by which an individual may most effectively do something for the benefit of humanity at large. Some members of the Society of Friends had felt the horror of slavery from the time of 


\section{CHRISTIAN DUTY IN A DEMOCRACY}

George Fox, who protested against it; ${ }^{1}$ but the institution, and the commerce which arose in connection with it, continued to grow; and even the protest of Woolman and Lay had little effect outside the circle of the Society of Friends. It was only when Clarkson and Wilberforce made it a political question, by bringing it before the British Parliament, that any real hope was awakened of removing this evil from civilised society. When it once became a political question the progress was rapid in regulating and abolishing the trade, and subsequently in freeing the slaves; and when a lead was given by one country, others were encouraged to follow on the same line. Since we see the enormous power which the State possesses for putting down evil, and the misery which may ensue from ill-judged action on the part of the State, it is a matter of the deepest regret that so many men should disparage political activity, and should put forward such flimsy excuses for neglecting to do their best in discharging the responsibilities of citizenship.

The duties of political communities lie in the mundane sphere, and the action of a Christian citizen does not necessarily differ from that of a

1 Whittier's Appreciation, prefixed to the Journal of John Woolman, p. 8. 


\section{CHRISTIANITY AND POLITICS}

man of any other religion, or of none. The doing of justice is a thing in which all good men of any religion will readily join; the forecasting of what is wise in the interests of the community, is an intellectual effort, and differences of opinion as to what is expedient need have no direct connection with differences of religious belief. Christianity can, however, supply a motive force which will lead a man to see that he is not justified in attempting to live for himself alone, but is bound to do his best for other men as well, and to make use of his privileges on their behalf. Christianity may do little to help us to forecast the precise nature of what is best for the community at any place or time; but it does afford an incentive for trying to see our duty and for persisting in doing it. It is the privilege of a citizen to take part in doing the duties of the community, in advancing the welfare within, and exercising a wholesome influence on the world without. Administrators and government officials of every sort may be conscientious, or they may be careless in discharging the public functions with which they are entrusted; and Christianity enjoins the conscientious doing of every duty. "Whatever thy hand finds "to do, do it with thy might." Public-spirited citizens will seek to do their part in supporting the action of civil authority, and in helping to 


\section{CHRISTIAN DUTY IN A DEMOCRACY}

bring good laws into effective operation. They may also feel called upon to supplement the activities of the State by voluntary action and to try to engage in duties, such as that of fostering religion, which they believe to be incumbent on the community, but which the community does not attempt to discharge or discharges inadequately.

The chief duty of the citizen to the community is that of civil obedience, and it seems unnecessary to add to what has been said on this point above; but the citizen also owes duties to the State in respect of his time and of his possessions.

A question has been much discussed in recent years as to the personal duty of the citizen to fit himself for the defence of his country. This duty has been recognised in most continental countries, where the danger of military invasion is very great; and the public generally acquiesce in the sacrifice of time, and the acceptance of onerous and costly service which private citizens may be suddenly called upon to perform; the personal duty is enforced by conscription. There is a readiness on the part of many British citizens in the colonies to fall in with this conception of the personal duty of citizenship. The fact that this duty has not been generally recognised in England has led, within the last few months, to a regrettable failure to fulfil a national obligation. English 


\section{CHRISTIANITY AND POLITICS}

I honour was involved in the maintenance of the integrity of Belgium; but when a blow was suddenly struck at the independence of that little nation, it was impossible for England to take as prompt measures as she would have desired to strengthen Belgium against invasion. The provision which had to be made for defending the shores of England from a German raid rendered it impossible to act as promptly, and on as large a scale as would have been desirable, in the sending out of an expeditionary force. It is impossible for an Englishman not to feel that, if the duty of the citizen to fit himself for the defence of his country had been more generally recognised, England might have been able to do more to save Belgium from the misery of being overrun by an enemy.

Duty to the community should also be borne in mind by men of means in deciding as to the investment of their property. In the seventeenth century, as we have seen, this question hardly arose. The capitalist was almost certain to invest his money in some fashion which would lead to promoting public interests by the development of home resources, and the promotion of intercourse with other countries. At the same time it was strongly felt, even then, that some employ- 


\section{CHRISTIAN DUTY IN A DEMOCRACY}

ments of capital were more beneficial to the community than others, and that it was desirable to give encouragement at national expense to those who used their wealth in such a way as indirectly to promote a great public interest, like the maintenance of a maritime marine. Since the time of Adam Smith the State has ceased to try to direct the employment of capital; but with the enormous increase of wealth in the nineteenth century, there is need to take the question into consideration, and not to assume that we are justified in neglecting it altogether. The publicspirited man will not content himself with seeing that he gets the largest possible return for his money, but will consider also the effect upon the good of the community.

It is generally recognised that in time of war the floating of a loan on behalf of either belligerent would be inconsistent with the spirit of neutrality, and that lending money is one method of increasing the resources of a State. The good citizen is surely called upon to consider whether he is justified in lending money to a foreign government, especially if there is reasonable probability that that foreign government is likely to become a hostile government. This principle applies less directly to the use of capital for developing the resources, increasing the communi- 


\section{CHRISTIANITY AND POLITICS}

cations, or otherwise promoting the material wealth of a country that is a possible enemy. The Englishman might surely be expected to show a preference in his investments for developing the resources of the British colonies, rather than for benefiting those regions with which he has no political affinities. There is also much room for consideration as to the manner in which capital is employed within a country. Those who can offer direct employment to labour are helping to relieve the wants of the poor in the most wholesome fashion. The employment of capital in agriculture or in any industry is sure to be a public benefit; while capital engaged in trading, though indirectly involved in the development of national activities, does not affect the market for labour so directly, or confer an immediate and regular benefit upon those who live by wages. The investment of capital in demoralising places of amusement, or in affording facilities for dissipation, may be exceedingly remunerative; but it is a form of sordid gain which the good citizen who desires to keep public interests in view, will be likely to avoid.

\section{DUTIES OF PRIVATE LIFE}

The Christian man is called upon to use the coercive power of the State to put down the evils of 


\section{CHRISTIAN DUTY IN A DEMOCRACY}

society, and thus to keep the national life up to as high a level as possible; but he has also duties to do of his own. He is called upon to aim at being better than his surroundings so that he may help to transform them; but he finds himself in a highly organised society where he has comparatively little freedom for personal action, and therefore but little personal responsibility. He is a part of a great machine, and if he neglects the running of that machine, he is likely to be crushed himself, and to bring injury to those with whom he is related by the ties of business.

This holds good of all questions in regard to the relations of capital and labour, where the remuneration of labour depends ultimately on the sale of the product. Impersonal organisation of business may be beneficial both to capital and to labour; but competition is so keen that there is little room for the capitalist acting personally, and on his own responsibility, to make changes in the terms of employment; there is therefore no Christian obligation to do what the employer has no opportunity of doing, though he may be of good service in suggesting remedial legislation.

At the same time there are various forms of employment which are not concerned with sup- 


\section{CHRISTIANITY AND POLITICS}

plying a market with finished goods, and where competition does not tie the hands of the employer. Domestic service is an obvious case in point, where the rate of remuneration and the conditions of life are entirely under the control of the employer personally, and where there is no excuse for ignoring the Christian duty of caring for the comfort and welfare of dependents. The days have gone by when the householder was justified in believing that the inculcation of the prudential virtues of diligence and thrift was his sole duty to those under his charge. The claim for opportunities to live a fuller life must be met; there is a different standard from that which was formerly in vogue, with regard to the conditions which are necessary for health. The Christian employer of such labour is responsible for ruling his house so that the dependents shall have the opportunity of living a wholesome human and Christian life.

Even in regard to employment where work is done with reference to a market, such considerations may be taken into account in regard to the manner in which the business is conducted. It is right to remember that the mechanism of society is not a mere mechanism, and it is a Christian duty to take any occasion that may arise for making a Christian influence felt. Among 


\section{CHRISTIAN DUTY IN A DEMOCRACY}

the merchants of the seventeenth century there were men who realised that their contact with foreign countries, for purposes of business, gave occasions which might be utilised for Christian objects; and the man who is anxious to do so will find that the contact which arises in the way of business does give opportunities for exercising a humanising and Christianising influence on his dependents. It seems a little thing, but it is important for the master to bear in mind that those he employs are human beings, and to endeavour to preserve the courtesies of life, and not to hurt their feelings by the manner in which he issues orders to his dependents or reproves blunders.

So much of the work of modern society is carried on by associations, that there is great need to consider the personal responsibilities of an individual with regard to the conduct of an association in which he has a part; and a good deal is said from time to time about the blame which attaches to shareholders in industrial or commercial companies. There is indeed a danger that the management of such companies may be carried on more mechanically, and with stricter attention to economic considerations, than would be the case where the personal influence of the head of 


\section{CHRISTIANITY AND POLITICS}

the firm can lubricate the running of the whole machine.

This consideration raises a question which was involved in the mediæval objection to usury. Has anyone a right to bargain himself out of responsibilities for the manner in which his business is conducted? The usurer, in the mediæval sense of the term, bargained himself out of the risks of business, and this was regarded as unfair to those who were actually carrying on the undertaking from which the man who had loaned his capital expected to gain. The debenture-holders and bond-holders, in public companies, have bargained themselves out of any share in the control of the business, and therefore out of any responsibility for what is done in conducting it. Should a scandal arise, such as has shocked the world in connection with the collection of rubber, would the debenture-holders be justified in regarding themselves as free from all blame? With regard to large associations, such as railway companies working in this country, it is clear that there are opportunities of criticism which are likely to bring any legitimate cause of complaint to light; and that real evils on a large scale can be more effectively dealt with by the coercive power of the State, than in any other fashion. The shareholder has also the opportunity, by subscription to benev- 


\section{CHRISTIAN DUTY IN A DEMOCRACY}

olent societies and other charities, to make some provision for the good of his dependents outside, and not to confine himself to the strictly business relations which exist between himself, as an employer, and his unknown dependents. Even the conscience of the most scrupulous railway shareholder may be satisfied by taking advantage of these opportunities, and he may feel that he is at once conferring a benefit on the public by the use made of his capital, and endeavouring to secure that the welfare of the employees as human beings shall not be forgotten.

When we recognise the various channels through which personality may make itself felt, and what far-reaching effects it may have in permeating society, we need not be oppressed by the pessimism which is so generally expressed. There is indeed reason to despair of the coercive force of the State; we see that its scope is limited, and that, however much may be accomplished by association for the pursuit of a common interest, this principle does not touch the root of the evil. But when these great social forces are regarded as instruments to be used by men with a strong sense of duty, we may feel that they are most potent weapons for putting down evil, and for fostering certain forms of good. If coercive powers and voluntary associations are supplemented by the 


\section{CHRISTIANITY AND POLITICS}

endeavour to bring Christian belief to bear habitually on personal conduct, the means are available by which the regeneration of society may be accomplished.

\section{CHRISTIAN ORGANISATION}

The question remains as to the best means of invigorating this sense of personal duty. There is no need to enter on invidious comparisons or to make exclusive claims for Christianity. Patriotism and other ideals have been very effective in taking men out of themselves, and saving them from being swayed by mere self-interest; it will suffice to say that since the time of our Lord this religion has shown a very great power of stimulating the sense of personal duty. It is by consciously endeavouring to foster this sense of personal obligation that the Church can best co-operate with the State. This is the specific contribution which the Church can make to the welfare of the community. Compared with the State, the Church has little coercive power, and in bygone days the attempts to exercise coercive power were not so successful as to encourage us to attempt them again. But Christianity can exercise an attractive influence, it can set forth ideals of personal conduct and provide incentives for striving to realise them. The influence is spiritual; 


\section{CHRISTIAN DUTY IN A DEMOCRACY}

it is not concerned so much with eradicating what is bad as with fostering and encouraging what is good. Its attractive power may draw forth the best that is in a man, and thus enlist his willing co-operation in the cause of good. This spiritual power can give insight to discern where duty lies and can inspire to perseverance in doing it.

Though the aim we set before us is distinctly practical, we need not yield to the temptation to disparage the intellectual side of Christianity; for intellectual elements are involved, if practical efforts are to be effectively maintained. The condemnation of intellectual error is most clearly shown in the practical results which follow from it. "Ye shall know them by their fruits." Seventeenth-century Calvinism, by its insistence on the overwhelming majesty of Divine Omniscience and Omnipotence, had a depressing effect on human activity. It had an affinity with fatalism which, while it may call forth unstinted devotion on the part of the man who believes himself to be a chosen instrument of God, condemns others to feel the uselessness of human effort, and leaves little scope for the cultivation of personal virtues. Again, the Deism, which was so widely diffused in the eighteenth century, by accustoming men to think of an impersonal God who had 


\section{CHRISTIANITY AND POLITICS}

created a mechanical order in the Universe, deprived religion of the confidence in a Divine Father and the sense of a personal duty to Him which had been revealed to the world by Christianity. Since theological errors may be so fatal to the influence of Christianity as a practical force in the world, intellectual efforts to detect such error and to guard against it are not useless and are not thrown away, even though this intellectual influence on the doing of Christian duty is very indirect.

The work of the Church in inspiring and fostering the sense of personal duty can be most effectively done by setting forth the encouragement which may be derived from the lives and examples of other men; what they have done shows what is possible to us. As Robert Browning says: "The secret of goodness and greatness is in "choosing whom you will approach and live with, "in memory or imagination, through the crowding, "obvious people who seem to live with you."' We cannot afford to neglect any study that enables us to feel the inspiration that is given by human lives.

The life of our Lord stands unique and alone,

1 Letters of Robert Browning and Elizabeth Barrett (9 July, 1816), II, 318. 


\section{CHRISTIAN DUTY IN A DEMOCRACY}

with intense patriotic enthusiasm, and a willingness to sacrifice Himself utterly. The rites which He ordained are the means by which men and women throughout all ages and in all lands may be brought into closest conscious union with His life; and in all the struggles of the saints in every age, there is a manifestation of the Christian spirit in circumstances in which our Lord was never placed, and under conditions which may be more familiar to us than those of His life in Palestine. In the lives of those who have departed in Christ's faith and fear, there is an example which may help us to interpret our own Christian duty, and may encourage us to do it. The work of the Christian Church may be most effective when it is catholic, and ready to draw examples of Christian heroism from the men, in any age or at any time, who profess and call themselves Christian.

Scholarship can enlarge the range from which inspiration is drawn by leading us to the Old Testament as well. The more we can study that collection of books so as to get at the personality of the holy men of old who helped to compile it, or whose doings it describes, the more we shall feel the reality of the personal power of religious influence. The careiul study of philology, and the purely scientific investigation of literary forms, 


\section{CHRISTIANITY AND POLITICS}

and of place and time of writing, are necessary preliminaries to obtaining a vivid conception of the personal faith and struggles of men and women in pre-Christian times. But the more we can apprehend their conditions and the victories of their faith, the more keenly may we feel it our duty to live up to the fuller light we have received.

Christianity, in all its aspects, cannot have its full effect upon society unless attempts are made to bring it to bear, not only on those who are consciously attracted by it, but on all and sundry, the indifferent as well as the hostile. No better method of attempting this has been suggested than the organisation of the Christian Church, on a local basis. In seeking to increase the effectiveness of Christian influence in Scotland, Dr. Chalmers ${ }^{1}$ contended strongly that territorial organisation was the system by which the greatest economy of effort might be secured, while yet that effort was so directed as to bring the whole population within its range, and to leave none who were beyond the sphere of its influence. Thus organised the work of the Christian Church may be adapted to each, while it reaches all. The principle of territorial organisation, which has a long history in Virginia, and has been maintained by

1 Chalmers, Civic Economy of Large Towns, I, chapters 2, 3, 4. 


\section{CHRISTIAN DUTY IN A DEMOCRACY}

Episcopalians in the United States, has recently found more general acceptance. "ResponsibilityDistricts" have been adopted by many denominations, in New York and other cities, as an essential step to grappling with the problems they present. $^{1}$ In this way the sense of neighbourliness, which is natural to human beings living in society, may be employed for the ministration of Christian charity and for union in common worship.

There are many complaints of widespread indifference to Christianity in the present day, and men are likely to be indifferent to a political Christianity, which has no message of its own to offer, but is content with backing up the crude efforts of the State. They are likely to be indifferent to a Christianity which pursues and is wholly absorbed in intellectual speculations and literary pedantries, as if they were an end in themselves. But the world is ready to respond to a Christianity which sets forth a faith in the living power of God and holds out fresh hope for mankind; and which, by fostering the sense of personal duty, can exercise an immediate and a far-reaching influence in the regeneration of society. We have no need to despair in presence of the perplexities of

1 Federation, published by the New York Federation of Churches, viI, no. IV, 2583. 


\section{CHRISTIANITY AND POLITICS}

the day; there is a call to every Christian man to use the extraordinary power in the hands of the State for repressing the evils among the masses, and also to seek to make his own personal life a better expression of the mind of Christ. 
APPENDIX 



\section{APPENDIX}

\section{THE ATTITUDE OF THE CHURCH TOWARDS WAR}

The apostles as witnesses to the Divine Power of their Lord were charged with the message to convince mankind of His power to forgive sins, and to implant in them the assurance of a resurrection from the dead. They were convinced that this faith would leaven human society, as it had already regenerated their own lives, but they had no definite rules to lay down for the conduct of human society: they had a spiritual truth to reveal, and this was the secret of their success. They were not primarily reformers of secular society, and so they had no definite rules to lay down for civil society in every age. They expected that the present evil world would be swept away and a heavenly realm of perfect peace and happiness be established, but they did not single out war as one special feature of the present evil world to be dealt with by itself. And so, though the spirit of Christian doctrine is wholly opposed to War, as generally caused and habitually conducted, there was not in primitive times any definite protest against this particular symptom in society of the evil disease in human hearts. The attitude which was taken at first has been on the whole maintained, both in the early Church and in recent times; but the Christian opposition to war has been expressed in different ways in different ages, according to the conditions of society and the circumstances of the day. There are three main periods to be distinguished. (1) The first four centuries and the acceptance of War 


\section{APPENDIX}

as inevitable in an evil world. (2) The consecration of War as an instrument to be used by the Christian Polity, from the fifth to the close of the seventeenth century. (3) The recognition that War is an evil, and that those who are responsible for appealing to force in international differences are guilty of a crime, is characteristic of modern times and has been incidentally discussed in the foregoing pages. The Christian antagonism to War cannot be formulated as an eternal truth for all time. The duty of a Christian towards War and his responsibility for War were necessarily different in the case of a slave in a heathen empire, and in the citizen of a democratic nation, who has a voice in the government of the country; but the constant effort to bring the spirit of Christ's teaching to bear on actual life, in each age in turn, has resulted in the growth of a body of experience, and has given rise to a certain consensus of Christian opinion.

\section{THE ACCEPTANCE OF WAR AS INEVITABLE IN AN EVIL WORLD}

The first Christians were conscious that they were members of a spiritual kingdom and owed allegiance to Christ as their king; but this did not absolve them from obedience to earthly monarchs, unless they were commanded to do something that was inconsistent with their allegiance to Christ; they were to be good citizens and so to commend their religion to those around them. This was all the more difficult as their neighbours and the heathen magistrates soon viewed them with suspicion; they could not understand what the men of the Third Race were aiming at. ${ }^{1}$ Justin Martyr ${ }^{2}$ and other apologists insisted that the kingdom at which Christ aimed was not of this world; though

1 Harnack, Expansion of Christianity, I, 300f.

2 Justin Martyr, A pol., I, 11, 14. (Migne, vi, 341, 348.) 


\section{APPENDIX}

their religion emanated from Judaism they were quite distinct from the Jews, and there was no danger of their taking up arms in defence of their religion as the Jews had done over and over again. ${ }^{1}$ They claimed to be a peaceable and unarmed folk. They found, however, great difficulty in keeping themselves true to their profession in a pagan atmosphere. There was much in heathen society that was likely to contaminate them, and it was not easy to be in the world and not of it; there were dangers of showing a greedy and grasping spirit in the conduct of their affairs, and they were put on their guard against the scandal caused by litigation or extortion. They could not countenance the shedding of blood for mere amusement, and kept away from gladiatorial shows; ${ }^{2}$ but so far as we can rely on the argument from silence, Christians do not appear to have been repelled by bloodshed in war. Pliny ${ }^{3}$ does not complain of them, and there seem to be no special warnings in regard to un-Christian conduct in connection with military service. Nor is this silence due, as is sometimes alleged, to a Christian habit of refraining altogether from serving in the army. Tertullian, in repelling the charge that Christians were infructuosi in negotiis, insists as a well-known fact that Christians take part in all the duties of life. "We make "use of the forum and the market, and the baths and "the shops and other social institutions of our age. We "both sail and fight by your side." 4 And his evidence at a later time is even more definite. "Tell me a war "for which we have not been useful and ready, even "when inferior in numbers, ready to be cut down as "none would be whose tenets were not that it is more

1 Origen, Contra Cels., viI, 26. (Migne, XI, 1457.)

2 Athenagoras, Leg. pro Christ., 35. (Migne, vi, 969.)

3 J.F. Bethune Baker, Christianity and War, 21. I am indebted to this admirable essay for many references.

4 A pol., 42. (Migne, 1, 490.) 


\section{APPENDIX}

"lawful to be killed than to kill." 1 The legend ${ }^{2}$ of the Thundering Legion is additional proof that there were Christian soldiers serving in the army of Marcus Aurelius; and the evidence of inscriptions ${ }^{3}$ shows that so far as monuments survive there were Christians in the army; though the number of soldiers among the Christians seems to have been much smaller in proportion than in the case of the heathen population.

Military service was uncongenial to Christians, but was not regarded as in itself wrong. Origen, in replying to Celsus, claims that there should be an exemption from military service for the Christians, as there was on grounds of ritual purity for the priests of certain shrines; ${ }^{4}$ but there was no suggestion that War was in itself wrong; his argument is that Christian priests do their share effectually by prayers to the true God; "keeping assuredly their hands pure but contending by "their prayers to God on behalf of all that are warring "justly." It is clear that the Great Alexandrian did not regard War as a thing in which the Christian was wrong to take part.

That military service was uncongenial to Christians is highly probable; and there may have been grounds for the complaint of Celsus that the pusillanimity and unwillingness of the Christians to fight was a danger to the Empire, ${ }^{5}$ or for the allegation reported by Gibbon that the unwillingness of Christians to enlist was the cause of the persecution under Diocletian. ${ }^{6}$ It seems more probable however that this was not the chief reason for the dissatisfaction of the military authori-

1 Apol., 37. (Migne, 1, 463.)

2 Tertullian, Ep. ad Scap., 4. 212 A.D. (Migne, I, 703.)

${ }^{3}$ Le Blant, Inscriptions chrétiennes de la Gaule, I, 84.

4 Origen, Contra Cels., viri, 73, 74. (Migne, xi, 1628.)

${ }^{5}$ Origen, op. cit., viII, 74. (Migne, XI, 1629.)

6 Gibbon, Decline and Fall, chap. xvr. Eusebius, H. E., vir, $4, x, 68$. 


\section{APPENDIX}

ties, but that they found the Christian soldiers were not altogether amenable to military discipline. The oath of military obedience ${ }^{1}$ and the participation in idolatrous rites gave rise to scruples and insubordination. The earliest known instance of a Christian refusing to serve in the army obtained the enthusiastic approval of Tertullian, ${ }^{2}$ but not for the reasons we might expect. "It is important," as Professor Bethune Baker says, "to notice what Tertullian means by those "offences against God which are inseparable from the "soldier's life. It is not the modern idea at all. The "special objections which he feels, the only offences "against Christian sentiment that seem to really weigh "with him, are the military oath - over which the hea"then gods presided, and the pagan ceremonial with "which so many military acts and operations were "invested." 3 But on whatever grounds, there seems to have been an increasing aversion to military service on the part of Christians in the third century; the position was felt to be a false one; and Cyprian appears to have commemorated several soldiers who suffered for their convictions. ${ }^{4}$ To the imperial authorities the attitude taken by Christians towards war presented a serious difficulty, and Galerius made vigorous efforts to force the Christians at his court and in his army to abandon their religion; ${ }^{5}$ he was at last able to persuade Diocletian ${ }^{6}$ to issue the decree which was primarily intended to deprive Christians of public posts in court. This raised the question of principle, so far as Christians were personally concerned, and of conforming to heathen formalities; it resulted in the martyrdom of

1 Tertullian, De idol., 19.

2 De Corona, chap. I. (Migne, II, 76.)

3 Christianity and War, 25.

- Ep., 34. (Migne, Iv, 323.)

5 Eusebius, $H$. E., virI, App. (Migne, xx, 793.)

- Lactantius, Liber de mort. persec., xI. (Migne, vir, 212.) 


\section{APPENDIX}

numbers of Christian soldiers. The extension of the persecution to the civil population seemed necessary if this doctrine was to be exterminated in the army, and a systematic effort was made to stamp out a religion which seemed to be mischievous to the State. ${ }^{1}$

With the Peace of the Church the duty of the Christian soldier was set in an entirely new light; the conditions of military discipline ceased to raise the question of principle as to loyalty to Christ, and St. Augustine discusses the spirit in which wars are conducted ${ }^{2}$ while he denounces wars of territorial aggression as robbery on a large scale. ${ }^{3}$ But this he treats rather as a question for kings and rulers, ${ }^{4}$ than for the private individual; in his eyes the main duty of the soldier was obedience; and hence there came to be a more complete reconciliation between the current consciousness of Christian duty and military discipline. St. Augustine dismisses the opinion that the shedding of blood was necessarily un-Christian as Manichæan, ${ }^{5}$ and insists that it is right to fight in a good cause and to maintain and extend the best earthly civilisation. ${ }^{6}$ The soldier's calling was a life of self-sacrifice and discipline; it had affinities with asceticism and was a vocation in which a man might be doing his duty to God. ${ }^{7}$

\section{THE CONSECRATION OF WAR}

St. Augustine not only summed up the experience of three preceding centuries of Christian life, but he had a vision of Christian Civilisation, which dominated the whole of the Middle Ages, and continued to exercise an

1 Eusebius, $H . E ., \mathrm{x}, 8$. (Migne, $\mathrm{xx}, 895$.)

2 Epist., cxxxviI, 14. (Migne, xxxiI, 531.)

${ }^{3}$ Civ. Dei, Iv, 6.

4 Contra Faust., xxir, 75. (Migne, xuII, 448.)

5 Ibid., xxiI, 74. (Migne, XlII, 447.)

${ }^{6}$ Civ. Dei, IV, 15, and xv, 4. (Migne, xuI, 124 and 440.)

7 Epist., CLxxxix, 4, 6. (Migne, XxxIIr, 855, 856; also XL, 1054.) 


\section{APPENDIX}

extraordinary influence on the Christian conception of duty till the close of the seventeenth century. He framed the thought of a City of God, in which the Spiritual should control and direct all the activities of the civil state, and thus employ them to give effect to God's Will upon earth. In the first ages men had viewed the heathen Empire, with all its marvellous organisation, as the foundation of civil order; but St. Augustine looked for a really Christian polity, in which secular authority, with all its powers and opportunities, should be consciously governed by spiritual aims. The use of force by the State, either within by the magistrate, or without in war with the enemies of the Christian polity, became consecrated; to engage in war for such purposes was regarded not only as allowable, but as a Christian duty.

This view of a Christian polity living and working in actual conditions of place and time gave a new conception to the work of missions. The spread of the gospel was not thought of, as it had been in the first ages and is again to-day, as the conversion of individuals, but as the diffusion of Christian institutions which would mould and form Christian habits of life. Appeals were made to barbarian potentates, so that their tribes might accept the Christian faith; it was the easiest means for establishing peace on the borders, and security in the centres of Christian life. Religious belief and political aims were intimately blended in the wars of Charles the Great, and the forcible conversions of the Saxons; and the same motives were conjoined in the enthusiasm of the Crusaders for rescuing the Holy Sepulchre from the Infidels. There was no sense of incongruity in the use of such violent means for the expansion of the Christian polity.

The consecration of warfare as the means for the spread of the Christian polity is also clearly brought 


\section{APPENDIX}

out in the institution of the military orders. ${ }^{1}$ They were the outcome of a desire to devote the bravery of soldiers and the discipline of an army to the cause of Christ. The story of the Knights Templars shows how earnestly the founders of the order were desirous of dedicating themselves to the service of God in the fashion in which they felt they could serve him best; and the ceremonies of initiation and the rule of the order ${ }^{2}$ preserved the consciousness of this ideal, - however much members of the order may have lost the spiritual side. It is, at all events, clear that they helped to introduce a higher standard into secular life. The religious desire to carry on war in a Christian fashion, restraining lust and passion and honouring a brave foe, was one of the sources of Chivalry; and there is a contrast between the barbarism of the heathen invaders, or the anarchy of the Dark Ages, and warfare as conducted by the Crusaders.

While the Church in the Middle Ages regarded War as a thing that might be consecrated by being used for the highest purposes, there were also constant protests against unconsecrated war - the maintenance of private feuds and the cruelties exercised towards the peaceful inhabitants. The reign of Stephen offers the best illustration from English history of what was involved in letting feudal anarchy have free play. "When the traitors perceived that he was a mild man "and a soft and a good, and that he did not enforce "justice, they did all wonder. They had done homage "to him and sworn oaths, but they no faith kept; all " became forsworn and broke their allegiance ... for "they filled the land with castles. They greatly op"pressed the wretched people by making them work "at these castles, and when the castles were finished

${ }^{1}$ St. Bernard, De laude novce Militice. (Migne, cLxxxII, 921.)

2 Addison, Knights Templars, 14. 


\section{APPENDIX}

"they filled them with devils and evil men. Then they "took those whom they suspected to have any goods, "by night and by day seizing both men and women, "and they put them in prison for their gold and silver, "and tortured them with pains unspeakable, for never "were any martyrs tormented as these were." ${ }^{1}$ The advent of a strong king helped to bring this anarchy to an end in England; but in the north of France it was checked by the steady action of the Church in bringing spiritual censures to bear, thus enforcing respect for promises, and securing a respite from this militarism. The right of private warfare was limited by maintaining the truce of God; while attempts were made in one Council after another to secure the churches, the clergy and the religious, the cemeteries, children, women, pilgrims and labourers, as well as the instruments for manual work in the enjoyment of constant peace. ${ }^{2}$

So long as the ordeal of battle was a recognised form of judicial procedure ${ }^{3}$ it was obviously impossible to put down war altogether, but it was practicable to advocate other methods of judicial procedure, and to limit the damage inflicted by war. The Church was successful in the task she set herself, because she concentrated her attention on the passions that gave rise to private war; and because spiritual censures and the deprivation of spiritual privileges were very effective weapons for enforcing her authority. Experience of the blessings of peace helped men to realise that the interests of the community - especially of the Crown and of the labouring and commercial classes - were promoted by the cessation of war; but the action of the Church was directed towards religious aims, and was conducted by spiritual means.

1 Anglo-Saxon Chronicle, A.D. 1137.

2 Semichon, La Paix et la Trêve de Dieu, I, 36.

${ }^{3}$ G. Neilson, Trial by Combat. 


\section{APPENDIX}

The Papacy, as the head of Latin Christendom, had exercised an enormous influence in reducing the barbarity of war, but the authority of Rome, as an international arbiter, was undermined when it came to be generally felt throughout Western Europe that the government of the Church had become secularised; the Church, as a temporal power, was keenly concerned in Italian politics and could not be accepted as a disinterested arbiter, while in large areas the censures of the Roman Church had ceased to obtain respect, or to restrain those who were eager to pursue their personal interests by any means in their power. The revolt against the authority of the Pope almost necessarily resulted in an outbreak of embittered struggles: to the Catholic powers it appeared a religious duty to stamp out the rebellion against the Spiritual Head of Christendom; to the people of Great Britain, the Lutherans and the Huguenots, it appeared a religious duty to maintain a struggle against a secularised Christianity which was endeavouring to suppress the free growth of national life. In Christendom, as severed by the Reformation, War was more directly associated with Religion than it had ever been on European soil before. At the disruption of Christendom, there seemed to all parties to be a clear call to employ War for spiritual purposes. The Reformers of the sixteenth century were still true to St. Augustine's hope of establishing an earthly polity in which Christian ideals should be the supreme guide in all the relations of life. Luther and Cranmer relied on Christian Princes to use their power to maintain traditional Christian institutions, and thus to create a national Christianity which should be free from the abuses that had destroyed its spiritual influence. Calvin and his followers endeavoured to substitute a new and scriptural Christian polity, but also thought that it was not merely allowable, but a duty for the Christian man to fight in 


\section{APPENDIX}

defence of the true Church. The Wars of Religion in France and the Thirty Years' War in Germany were the consequence of this conviction as to religious duty; and it was strengthened by the consciousness that a war of aggression had been divinely sanctioned in the Old Testament. The extermination of the Pequod Nation seemed to the men of Connecticut to be God's means of giving his beloved rest; the religious zeal of the Covenanters in Scotland expressed itself in rebellion against an uncovenanted king.

The perpetration of the worst horrors of war in the name of Christianity caused such a shock to devout feeling that there was a strong reaction, and the opinion began to be expressed that the use of force was under all circumstances inconsistent with Christianity. This was the attitude of the Anabaptists; to a considerable extent the doctrine was new, though it had much in common with the teaching of the Montanists. The Montanists had pressed scriptural teaching as a reason for abstaining rigidly from the incidental evil of heathen society, but the Anabaptists appear to have interpreted the New Testament as condemning the whole framework of Civil Society. There are several of the Thirty-Nine Articles which are directed against them. " "The laws of the Realm may punish Christian "men with death, for heinous and grievous offences. "It is lawful for Christian men, at the commandment "of the magistrate to wear weapons and to serve in "the wars." Again, "The Riches and Goods of Chris"tians, are not common as touching the right, title "and possession of the same, as certain Anabaptists do "vainly boast;" and so also in regard to a Christian man's oath. It is to be noticed that the Anabaptists did not so much object to war because it involved the slaying of a fellow creature, as on more general

1 Gibson, Articles, xxxvir, xxxviII, xxxix. 


\section{APPENDIX}

grounds; they denied any distinction between official and private life, and held that what was unlawful for the private Christian was also to be condemned when done by a magistrate; at least this is the impression that is derived from the language of those who condemned them. They certainly appear to have committed themselves to a false spirituality in the limitations they laid on the power of the magistrate for the punishment of evil-doers.

From this point of view it followed that War was in itself wrong; that since a private person might not kill in a private quarrel, a collection of private individuals were not justified in using force either. The principle that War was under all circumstances and in itself wrong, which St. Augustine had condemned as Manichæan, was taken up by the Anabaptists and, descended to George Fox, it was enthusiastically adopted by those who formed the Society of Friends. There can be no doubt that much plausible argument can be adduced in favour of their position from the New Testament. The Early Christians were precluded from taking an active part in public life, and they made experiments in communism; it would be easy to argue that they maintained a merely negative attitude towards civil government; but it is not in accordance with the teaching of the Gospels and Epistles to say that this negative attitude is enjoined on Christians for all time. The odium which was expressed towards the Quakers, both in England and America, was due to the fact that they were able to take advantage of the existence of Civil Society, while they professed to hold aloof from it; they were not consistently following the example of the Early Christians, as they had no scruple in securing their rights by litigation, and had no rules to enable them to refrain from hard bargains in business. Apart from such apparent inconsistencies, the real weakness of Quakerism and of 


\section{APPENDIX}

all forms of Quietism is that since they regard Christianity as having a negative attitude towards civil affairs, they have no positive teaching to give as to the way in which Christianity may be brought to bear on political life and national duty. The problem as to the method of reconciling his duty as a Christian with his duty as a citizen is left to each individual to solve for himself, often by some compromise which leaves his conscience uneasy.

The exaggeration which insists that War must be avoided, as in itself an evil thing, by Christian men under all circumstances, had re-introduced the cleavage between civil society and Christianity which had come to an end at the Peace of the Church. On the one hand, Christianity appears to be represented as aiming at an external change in society which most men regard as impracticable, and as being futile and ineffective in so far as it has not secured it. On the other hand, the State and politics are regarded as being of the earth earthy, and left to be controlled by the play of private interests, and without any conscious reference to spiritual truth. Besides this, it is not possible for the Christian who takes this view of civil society to maintain a merely negative attitude towards the government of the country in which he lives, and on which he relies for protection; he is almost certain, in refusing to conform to the institutions of society, to undermine its authority, even if he does not actively oppose it. And thus he is in danger of being brought into direct conflict with apostolic teaching as to the Christian attitude towards civil magistrates.

Further, this negative attitude is neither inspiring nor effective. Christianity as thus represented has no power to encourage the citizen in the discharge of public duty either in peace or in war. Those who believe that war is an un-Christian thing are not ready to 


\section{APPENDIX}

admit that the profession of a soldier is permissible for a Christian, still less to recognise that the soldier by his readiness to sacrifice his life in giving effect to a national duty, and by submitting to discipline, is in a position to cultivate devotion to duty and chivalry, and thus to be an example to civilians. The recognition and cultivation of those virtues is the best safeguard against the temptation to which a soldier may be specially exposed. Nor is this negative attitude fruitful so far as the public is concerned, for it does little to kindle enthusiasm, or to advance the cause it has at heart. The spread of private opinion that slavery was un-Christian was very slow indeed, even among the Society of Friends, and failed to create an atmosphere in which slavery could not exist. The testimony of the Quakers does not seem to have had much to do with the extraordinary change in the attitude of society towards War which took place at the end of the seventeenth century. The conflicts between different types of Christian polity had created a horror of war as an evil, and had worn out the strength of the conviction that any one ecclesiastical system was exclusively Christian. With the close of the seventeenth century the attempt to identify the kingdom of God with any particular national polity ceased so far as the government of Great Britain was concerned. The recognition of two national polities, with one Crown and one Parliament, was an abandonment of the exclusive claims of Anglicanism or Presbyterianism to control national life; and the plantations, in Maryland and Carolina, were founded in a secular interest and with no definite religious affinity. St. Augustine's conception of the City of God had ceased to dominate public sentiment in England, and the government no longer regarded it as a duty for the nation to fight on religious grounds.

The experience of the sixteenth and seventeenth 


\section{APPENDIX}

centuries has not been in vain. We have attained to a firmer hold on the conception of the kingdom of God as spiritual; and there is a general opinion among Christians that an appeal to arms is never justified as a means of advancing the progress of that kingdom. We feel that there is an inconsistency in attempting to promote Christ's cause in the world, by means which Christ habitually disclaimed. The distinction on which the Second Century Apologists insisted, between the methods of Judaism and the methods of Christianity, has been reaffirmed by the experience of subsequent ages.

On the other hand, when a nation engages in war, for an object that frankly concerns earthly life and earthly schemes, it is not necessarily to be condemned as unchristian. We are bidden to make "friends of the Mammon of Unrighteousness"; and we ought to aim at so conducting ourselves in warfare as to be the better for having come through the ordeal. Recourse to War may be essential for the preservation of national life; participation in it may be a national duty. But for a country to engage in War light-heartedly, or to treat it as an excuse for the indulgence of cruel and cowardly passions towards a peaceful population, is to disregard Christianity altogether. The protest, which was made by the Church in the Middle Ages, is needed still, so long as there are men like Bernhardi, who glory in War for its own sake, and claim that this habit of mind is compatible with Christianity. ${ }^{1}$

1 Germany and the Next War, p. 29. 

INDEX 



\section{INDEX}

Alms-giving, 78.

Anabaptists, the, 259, 260.

Angell, Norman, 212.

Anglo-Saxon peoples, and the Roman Church, 25-29.

Army, British, percentage of various denominations in, $105 n$.

Band of Maintenance, the, 66, 67 .

Baxter, Richard, 88; quoted, 97.

Beggars, treatment of, in Scotland, 86.

Bible, Cranmer's, 31.

Bible, the, in the Reformation, 34; its use by the English Church, 34-36; misuse of, 54; danger of misusing, 87-91.

Book of Common Prayer, 61.

Booth, General, 134.

Bray, Dr. Thomas, 152.

Bright, John, 80.

Browne, Robert, quoted, 92, 93, 94.

Browning, Robert, 242.

Burial, Christian, 99, 100.

Burke, Edmund, 158.

Butler, Bishop, on relief of the poor, 156.

Calvin, John, 63; on taking of interest, 71 .

Calvinism, reaction against, 128.

Capital, use of, 50-52; freedom for, 58, 71, 72, 87; and labour, $80,81,82,234,235$; selfish, $143,160-62$; cannot be trusted with irresponsible power, 171; relation to the community, 232, 233, 234.

Carlyle, Thomas, 77.

Catholic Social Movement, the, in Belgium, 19, 20.
Chalmers, Thomas, 77, 88-90.

Chamberlayne, John, on the Religious Societies, 130.

Charity, personal, 48, 78, 79 .

Children, in industry, 158, 170 . 173.

Chishull, Edmund, on the duty of the Christian merchant, 146, 147.

Christian associations, 106-11.

Christian organisation, 240-46.

Christian polity, national, 58, 63-73.

Christian principles, 23, 24 .

Christian realm, administration of a, 45-58.

Christianity, and the nation, 2,3 , $5,14,108$; method of, 4; and the individual, $6,7,198,199$, 222; and social conditions, 15; on the side of the rich, 88; political, 189-99; and public spirit, 222; supplies a motive force, 230 ; the intellectual side of, $241,242$.

Church, the, as the handmaid of politicians, 189-92; attitude towards war, 249-63.

Church and State, in England, 30-62; two aspects of the same community, $30,45,46,110$; system of rule in, anomalous, 52; the old system restored, 112; co-operation between, 240 .

Church of England, truly national, $32,33,39$; its appeal to the Bible, 34-36.

Churches, responsibility of, 190 , 191.

Citizen, duties of, 226-34.

Citizenship, in a democratic state, 118. 


\section{INDEX}

Civil obedience, grounds of, 11726 ; chief duty of the citizen, 231.

Class interests, and national interests, 200-18; growth of, 200 ; inadequacy of, 205-10; may fail to promote the common good, 208, 209; and individualism, 210.

Clergy, the, in politics, 194, 195, 197.

Coal mining, in Scotland, 16062.

Coercion, of a free people, impossible, 53, 62; the right of, 58-62; and humanitarianism, 167-99; and the duties of others, 174-78; between nations, 182; has limitations, 198.

Collections at church doors, 76 .

Collective bargaining, 173.

Community, the, Christian, 74, 95; and the individual, 100, $101,124,145,163-65,169$; an organic whole, 106, 123; sense of duty to, 125; duties of, 13459 ; prosperity of, 159-66.

Concessions to commercial companies, 61.

Conscience, the supremacy of, 92-126; of the individual, 100 , 101.

Co-operation, in production, 202 , 203; in education, 206; consonant with Christianity, 207; does not foster sense of duty to the community, 207, 208.

Co-operative stores, 201, 202.

Corn Laws, repeal of, 173.

Counter-Reformation, the, 14 .

Cromwell, Oliver, compelled to do public penance, $\mathbf{5 5}$.

Crown, the, and the people, 3640 ; loyalty to, 80 ; duty of obedience to, 117, 118.

Democracy, Christian duty in, 219-46.

Domestic service, 236.
Duty, personal, 7; official, 10002 ; of citizenship, 102, 103, 114; of civil obedience, 11726 ; to the community, 125 , 126; substitutes for the sense of, 200-05, 215; Christian, in a democracy, 219-46; need of a personal sense of, 216, 221, 240 ; two fundamental principles, 224, 225; of a citizen, 22634 ; of private life, 234-40.

Ecclesiastical courts, 53-55, 127. Ecclesiastics in civil offices, $\mathbf{4 5}$, 46.

Economic dependence, 214, 215. Economic forces, 38, 39, 61, 116. English Church, the, truly national, 33, 39; attitude toward the Bible, 34-36.

Feudal anarchy, 256, 257.

Fish days, 49.

Fox, George, 100, 103.

Free Trade, 195, 196, 214.

Friendly societies, 203, 204.

Friends. See Quakers.

Gambling, 225.

Gathered churches, 92-100.

George, Lloyd, 189-91, 192.

Geree, Rev. John, on self-interest, 143-45.

German Catholic Congress, the, 15.

Gibson, Edmund, Bishop of London, 148.

Guilds, mediæval, 200, 201.

Hampden, John, 120.

Harvest, Rev. George, on the planting of Georgia, 136, 137.

Hawes, Dr. William, founder of the Royal Humane Society, 157.

Henry VIII, 12, 30, 31, 63.

Heriot, George, 79.

Home Rule, 27, 28.

Hospitals, development of, 15355. 


\section{INDEX}

Humanitarianism, and coercion, 167-99; a palliative, 186; and war, 187, 188; deprecates nationality, 188.

Hutchinson, Anne, 109.

Independents, and the supremacy of conscience, 92-126; antagonists of existing parties, 93, 94; divided life into two spheres, 95, 110, 114; in Holland and the New World, 106, 107.

Individual convictions, assertion of, $121,123$.

Individualism, and class interests, 210.

Individuals, and society, 91, 100, $101,124,145,163-65,169$; personal religious life of, 131-34; influence of Christianity on, 198, 199; and associations, 237, 238.

Inquisition, the, 13, 32 .

Interest, on money, 50, 70-72.

International agreement, 212, 213.

Itinerant preachers, 97, 98.

Jesuits, the, 14.

Kennett, White, Bishop of Peterborough, on sacrificing religion for gain, 148.

Ketteler, W. E., Bishop of Mainz, 15, 16.

Knights Templars, 256.

Knox, John, 75.

Laissez-faire, principle long accepted, 167, 168; reaction against, 168, 169; abandoned, $173,174$.

Landed gentry, 41-44.

Leadership, the art of, 62 .

Leisured class, and public service, 44.

Levant Company, The, 146.

Livesey, Sir George, 203.

Locke, John, 116.

Love of country, 188.
MacKenzie, Sir George, 84.

Magistrates, empowered to punish, 69,101 ; duty and opportunity of, 149, 150.

Mapletoft, Rev. John, on care of dependents, 151, 152.

Mass, celebration of, 74 .

Material prosperity, 142, 143. 160,164 .

Merchant Adventurers, 56, 57.

Methodism, 131-34.

Military service, and the early Christians, 252, 253, 254.

Mills, Dean, of Exeter, on the health of the poor, 149.

Minimum wage, 173.

Ministers, spiritual independence of, 72, 73; in politics, 19397.

Monasticism, 35, 64.

Money, getting and using, 50, 51 .

Montanists, the, 259.

National interests, and class interests, 200-18; conflicting, 211.

National jealousies, 213, 214.

National life, 30-44, 188.

Nonconformists, English, 60.

Obedience, civil, 117-26, 231.

Old-age pensions, 181.

Old Testament, the, and the Scottish Reformers, 68-70, 81; value of, 243.

Owen, Robert, 202.

Pacifism, 2.

Papacy, the, spiritual and civil authority of, 8-11; secularisation of, 11, 12, 258; an international arbiter, 12, 13, 21; external spiritual authority, 1425; limitations, 22, 23; and Anglo-Saxon peoples, 25-29.

Parkinson, Dr., on the claims of the sick poor, 154, 155.

Parochial relief, Scottish, 76, 77. Parochial schools, 75.

Parochial system, of the Church 


\section{INDEX}

of England, 94, 96; abolition of, in South Wales, 96, 97, 99. Party government, 193, 227.

Party politics, 191, 193, 194, 195, 226.

Passive resistance, 120.

Patents, 57.

Peasants' rebellion, the, 122.

Peel, Sir Robert, 158, 173.

Penn, William, 103, 108.

Personal conviction, as basis of Church life, 92.

Personal Monarchy, the, 56, 58; breakdown of, 52,53 .

Personal responsibility, sense of, 180, 181.

Philanthropy, spasmodic and irregular, 168, 169.

Pinnell, Rev. Peter, on magistrates, 150, 151.

Political economy, 5 .

Polity, Christian national, 58, 92; scriptural model of, 63-73.

Poor relief, 47, 48, 76, 86.

Pope Benedict XV, quoted, 17, $21 n$.

Pope Leo XIII, quoted, 9, 10, 16, 17; Encyclicals of, 20-25.

Predestination and election, 128.

Presbyterian theocracy, 73-86; the Bible in, 87.

Presbyterianism, and the supremacy of Scripture, 63-91; in Scotland, 115.

Public benefits and justice, 175, 176.

Public health, care of, $171,172$.

Public opinion, 175, 190.

Public spirit, religion and, 12766.

Pulpit, influence of the, 135.

Puritans, the, 112, 113.

Quakers, and administrative duties, 100-06; their sense of personal duty, 100; declined duties of citizenship, 100, 101, 102, 104; their use of the New Testament, 102; attitude toward war, 260, 262 .
Reduction of armaments, 187.

Reformation, Christendom and the, 8-29; the Bible in, 34-36.

Reformation, the English, 13, $30,63,64$.

Reformation Movement in Scotland, the, 63-73.

Religion, a force in political life, 2,3, 219; and social conditions, 15 ; eliminated from politics, 114-16; and public spirit, 12766 ; indifference to, 219.

Religious mission, England's sense of, 40, 41, 136.

Religious toleration, 219.

Ridley, Glocester, on the planting of Georgia, 136.

Robertson, F. W., quoted, 6.

Roman Catholic writers, 28, 29. Royal Humane Society, the, 156, 157.

Sabbath, sanctity of the, 74 .

Sadler, Michael, 169, 170.

St. Augustine on war, 254; the City of God, 255.

St. Francis, 11.

Salvation Army, the, 25, 134.

Seamanship, essential to an island realm, 49.

Self-discipline and growth, 12734.

Self-interest, $142-45,216,217$.

Serfdom, 83, 84.

Sermon on the Mount, the, 91 .

Shaftesbury, Lord, 169, 170.

Slavery, capitalist, in Scotland, $82-85$.

Smith, Adam, 167, 173.

Society for the Reformation of Manners, 152.

Spiritual independence, 72, 73.

State insurance, 176.

State interference, questionable, 167; may be desirable, 168, 171; may cause complications, 175,176 ; better for dealing with masses than with individuals, 177; reliance on, 178-88; may be injurious, 180 . 


\section{INDEX}

Stubbs, William, 119.

Synagogue of Satan, breach with the, 64,65 .

Terrick, Richard, Bishop of Peterborough, 137, 138.

Tertullian, on Christians in war, 251, 252.

Theocracy, Presbyterian, 73-86; in the Old Testament, 90, 91.

Time, responsibility for the use of, 224 .

Trade interests, in Scotland and England, 79, 80.

Trade unions, 172, 173, 204, 205, 209, 210.

Trimnell, Charles, Bishop of Norwich, 147.

Usury, 70, 238.

Wales, abolition of parochial system in, 96, 97, 99 .

War, the European, 1.

War, an anachronism, 1 ; always a pretext for, 21; attitude of various Christian bodies to-

ward, 105; duty of citizens in, Young, Arthur, 160.
118,231 ; not likely io cease in near future, 182, 183; duty to avoid occasions for, 184; conduct of, 185; real causes of, $187,189,213$; evil of, 211; and national interests, 212, 213; loan, 233; attitude of the Church towards, 249-63; Christian opposition to, 249, 250 ; acceptance of as inevitable, 250-54; consecration of, as a means of spreading Christian polity, 254-59; private, 256, 257; for spiritual purposes, 258, 259; considered wrong in itself, 260, 261; may be national duty, 263 .

Wealth, responsibility for, 225 . Wesley, John, and Methodism, 131-34.

Whewell, William, on national life, 139-42.

Williams, Roger, 108, 110.

Women and children, employment of, 170, 173.

Women's Suffrage, 180. 
(Che Atibraide pregd

CAMBRIDGE - MASSACHUSETTS

$\mathbf{U} \cdot \mathbf{S} \cdot \mathbf{A}$ 



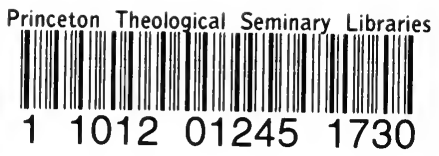

Date Due

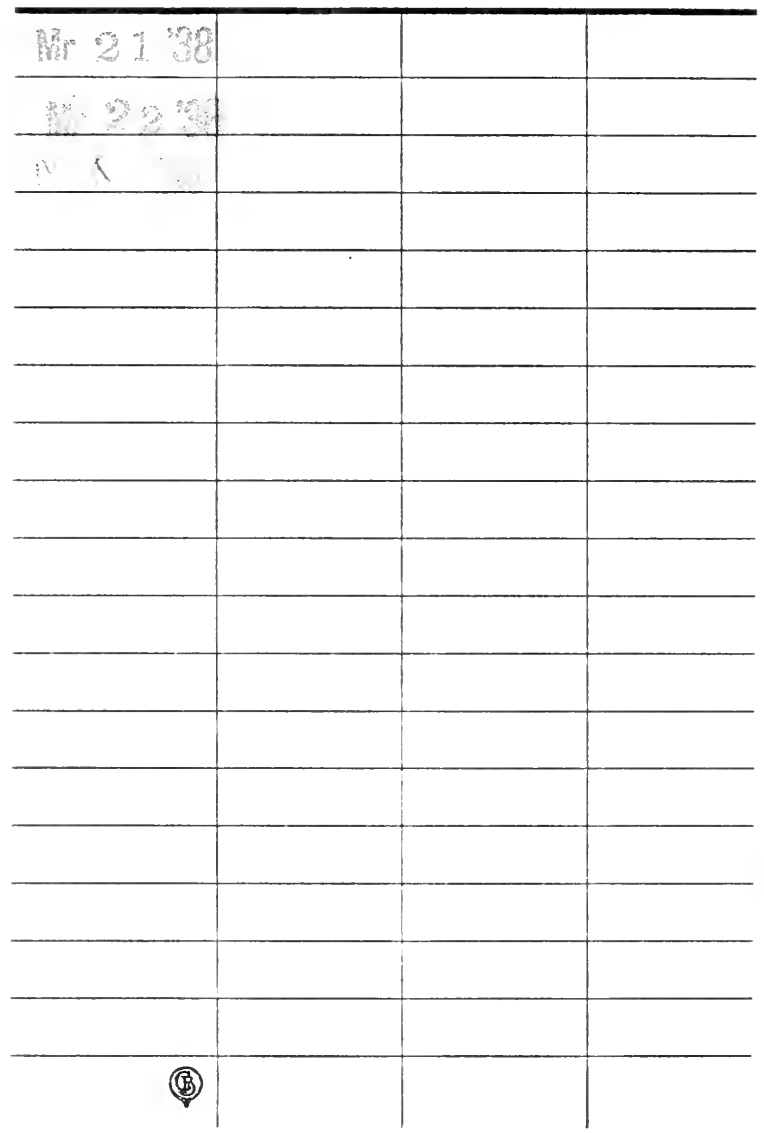





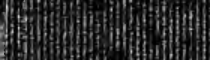

